MEASUREIENT OF REAERATION COEFFICIENTS

FOR SELECTED FLORIDA STREAMS

By Paul S. Hampson and John E. Coffin

U.S. GEOLOGICAL SURVEY

Water-Resources Investigations Report 87-4020

Prepared in cooperation with the

FLORIDA DEPARTMENT OF ENVIRONMENTAL REGULATION

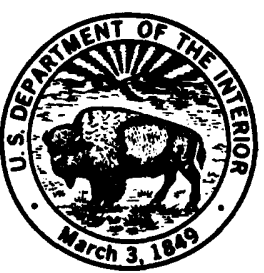

Tallahassee, Florida 
DEPARTMENT OF THE INTERIOR

MANUEL LUJAN, JR., Secretary

U.S. GEOLOGICAL SURVEY

Dallas L. Peck, Director

For additional information write to:

District Chief

U.S. Geological Survey

Suite 3015

227 North Bronough Street

Tallahassee, Florida 32301
Copies of this report can be purchased from:

U.S. Geological Survey Books and Open-File Reports Federal Center, Building 810 Box 25425

Denver, Colorado 80225 


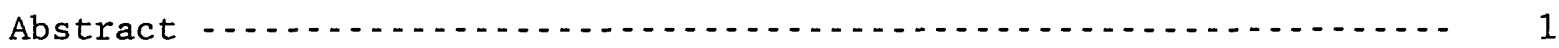

Introduction $\ldots \ldots \ldots \ldots \ldots \ldots$

Background - . . . .

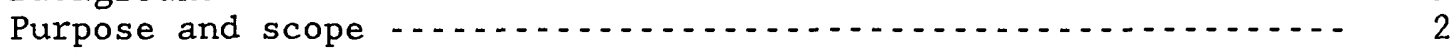

Hydrocarbon gas tracer techniques $\ldots \ldots \ldots$

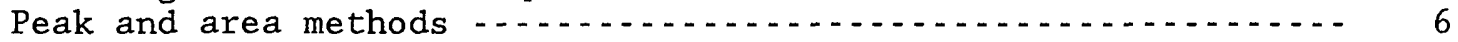

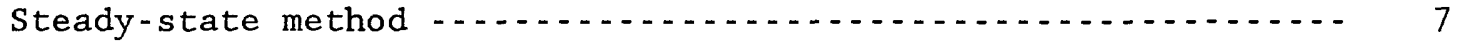

Methods of investigation _...

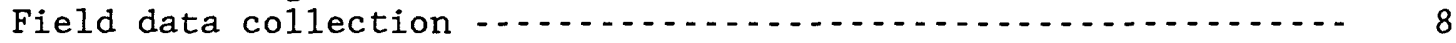

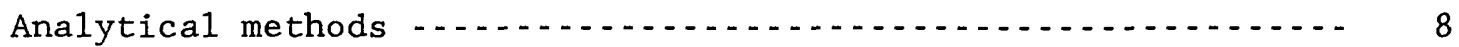

Error estimates -.....

Peak and area methods

Steady-state method -

Reaeration coefficient measurements $\ldots \ldots \ldots 11$

Peak and area methods _...

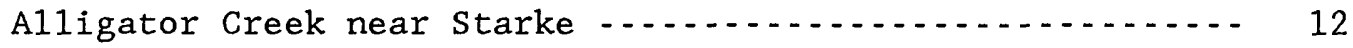

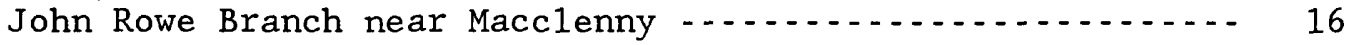

McGirts Creek-Ortega River at Jacksonville ................ 20

Country Club Creek at Jacksonville .................. 33

Unnamed tributary to Wills Branch at Jacksonville ...... 39

Peace River near Arcadia ............................ 43

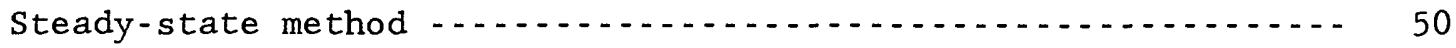

North Prong Alafia River at Keysville _..................... 50

South Prong Alafia River near Pinecrest ................... 54

Withlacoochee River near Bellville ......................... 57

Silversmith Creek at Jacksonville ........................ 61

Unnamed tributary to Christopher Creek at Jacksonville -..- 65

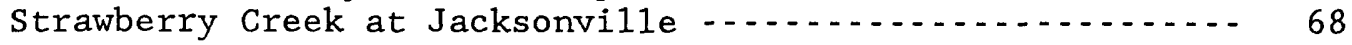

Evaluation of predictive equations -

Summary and conclusions -

Selected references - $\ldots \ldots \ldots \ldots$

Appendix I.--Estimation and propagation of experimental errors -... 80

\section{ILLUSTRATIONS}

Figures

1-3. Maps showing locations of:

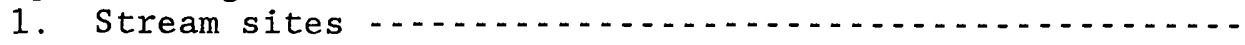

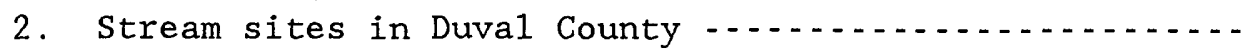

3. Hydraulic data for Alligator Creek near Starke .......

4-5. Graphs showing:

4. Traveltime-distance and dye concentration-time curves for Alligator Creek near Starke ..................... 14

5. Hydrocarbon gas concentration-time curves for

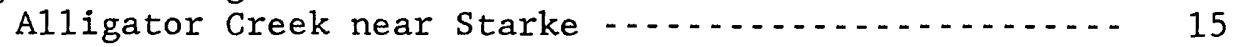

6. Map showing location of and hydraulic data for John

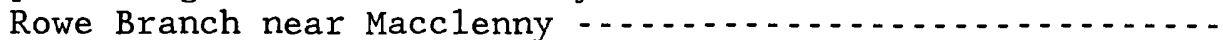

7-8. Graphs showing:

7. Trave1time-distance and dye concentration-time curves

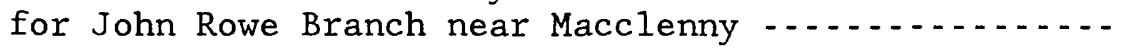
8. Hydrocarbon gas concentration-time curves for John
Rowe Branch near Macclenny
8. Hydrocarbon gas concentration-time curves for John
Rowe Branch near Macclenny




\section{ILLUSTRATIONS - - Continued}

Figures

9. Map showing location of and hydraulic data for subreach $A$

10. Graph showing traveltime-distance curves, dye concentration data, and hydrocarbon gas data for subreach A of McGirts Creek-Ortega River at Jacksonville .....................

11. Map showing location of and hydraulic data for subreach $B$ of McGirts Creek-Ortega River at Jacksonville ...........

12. Graph showing traveltime-distance curves, dye concentration data, and hydrocarbon gas data for subreach B of McGirts Creek-Ortega River at Jacksonville ...................

13. Map showing location of and hydraulic data for subreach $C$ of McGirts Creek-Ortega River at Jacksonville ...........

14. Graphs showing traveltime-distance and dye concentration-time curves for subreach $C$ of McGirts Creek-Ortega River at Jacksonville ...................

15. Map showing location of and hydraulic data for subreach $D$ of McGirts Creek-Ortega River at Jacksonville ...........

16. Graph showing traveltime-distance curves, dye concentration data, and hydrocarbon gas concentration data for subreach D of McGirts Creek-Ortega River at Jacksonville ..........

17. Map showing location of and hydraulic data for subreaches $E$ and F of McGirts Creek-Ortega River at Jacksonville ......

18-19. Graphs showing:

18. Traveltime-distance and dye concentration-time curves for subreaches $E$ and $F$ of McGirts Creek-Ortega

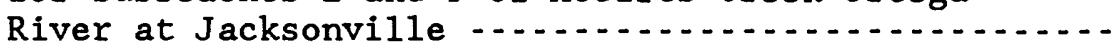

19. Hydrocarbon gas concentration-time curves for subreaches $E$ and $F$ of McGirts Creek-Ortega River at

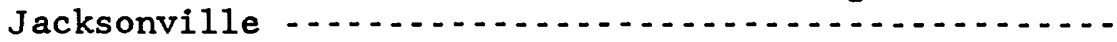

20. Map showing location of and hydraulic data for Country Club

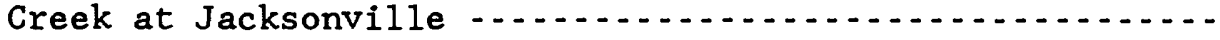

21-24. Graphs showing:

21. Traveltime-distance and dye concentration-time curves for subreach A Country Club Creek at Jacksonville -..

22. Hydrocarbon gas concentration-time curves for subreach A of Country Club Creek at Jacksonville ....

23. Traveltime-distance and dye concentration-time curves for subreaches B and C of Country Club Creek at

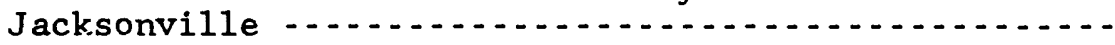

24. Propane concentration-time curves for subreaches $B$ and C of Country Club Creek at Jacksonville ...........

25. Map showing location of and hydraulic data for the unnamed

tributary to Wills Branch at Jacksonville ........................

26-27. Graphs showing:

26. Traveltime-distance and dye concentration-time curves for the unnamed tributary to Wills Branch at

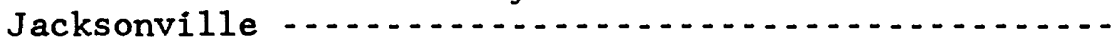

27. Propane concentration-time curves for the unnamed tributary to Wills Branch at Jacksonville ..........

28-29. Maps showing locations of and hydraulic data for:

28. Subreaches $A$ and $B$ of the Peace River near Arcadia ....

29. Subreach $C$ of the Peace River near Arcadia ............... 
Figures

30-31. Graphs showing trave1time-distance and dye concentration-time curves for:

30. Subreaches A and B of the Peace River near Arcadia -... 46

31. Subreach C of the Peace River near Arcadia ........ 47

32-33. Graphs showing ethylene concentration-time curves for:

32. Subreaches $A$ and $B$ of the Peace River near Arcadia .... 48

33. Subreach $C$ of the Peace River near Arcadia ......... 49

34. Map showing location of and hydraulic data for the North

Prong Alafia River at Keysville ..................... 51

35-36. Graphs showing traveltime-distance and dye concentration-time curves for:

35. Subreach A of the North Prong Alafia River at

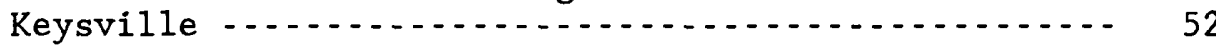

36. Subreach B of the North Prong Alafia River at

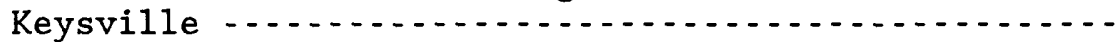

37. Map showing location of and hydraulic data for the South Prong Alafia River near Pinecrest ................................

38. Graphs showing traveltime-distance and dye concentration-time curves for the South Prong Alafia

River near Pinecrest ..............................................

39. Map showing location of and hydraulic data for the

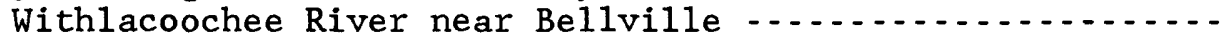

40-41. Graphs showing traveltime-distance and dye concentration-time curves for:

40. Subreaches $A$ and $B$ of the Withlacoochee River near

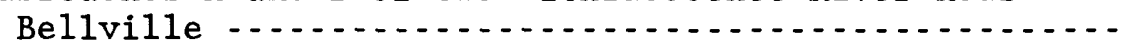

41. Subreach $C$ of the Withlacoochee River near Bellville --

42. Map showing location of and hydraulic data for Silversmith

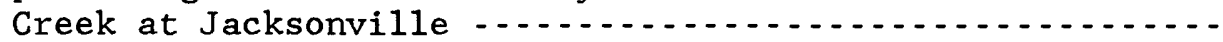

43-44. Graphs showing traveltime-distance and dye concentration-time curves for:

43. Subreach A of Silversmith Creek at Jacksonville, August 14, $1984 \ldots \ldots$

44. Subreach A of Silversmith Creek at Jacksonville, May 29, $1985 \ldots \ldots \ldots$ 9

45. Map showing location of and hydraulic data for the unnamed tributary to Christopher Creek at Jacksonville ........

46. Graphs showing traveltime-distance and dye concentration-time curves for the unnamed tributary to Christopher Creek at Jacksonville -...................

47. Map showing location of and hydraulic data for Strawberry

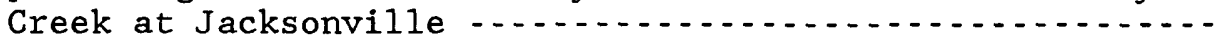

48-49. Graphs showing traveltime-distance and dye concentration-time curves for:

48. Subreach A of Strawberry Creek at Jacksonville, August 15, $1984 \ldots \ldots$

49. Subreaches A and B of Strawberry Creek at Jacksonville, May 29, 1985 $\ldots \ldots$ 
Table 1. Predictive equations for reaeration coefficients and standard errors of estimate of predicted versus

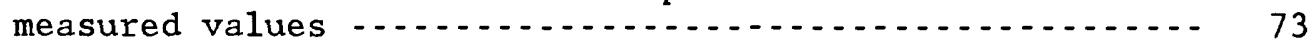

2. Regression coefficients and standard errors of estimate for adjusted predictive equations using predicted versus

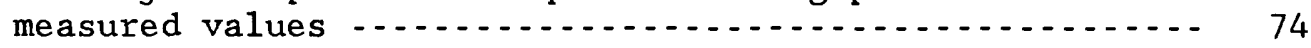

3. Seven modified predictive equations developed by non-linear regression for reaeration coefficients using measured data and standard errors of estimate of

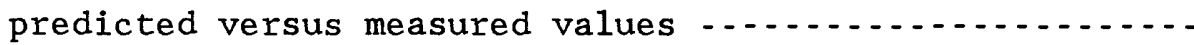

\section{CONVERSION FACTORS}

The following factors may be used to convert inch-pound units used in this report to metric (International System) units.

Multiply inch-pound unit

$\begin{array}{ll}\text { fcot (ft) } & 0.3048 \\ \text { mile (mi) } & 1.609 \\ \text { feet per second (ft/s) } & 0.3048 \\ \left.\text { square foot ( } \mathrm{ft}^{2}\right) & 0.0929 \\ \text { cubic foot per second }\left(\mathrm{ft}^{3} / \mathrm{s}\right) & 0.02832 \\ \text { foot per second squared } & 0.3048\end{array}$

\section{To obtain metric unit}

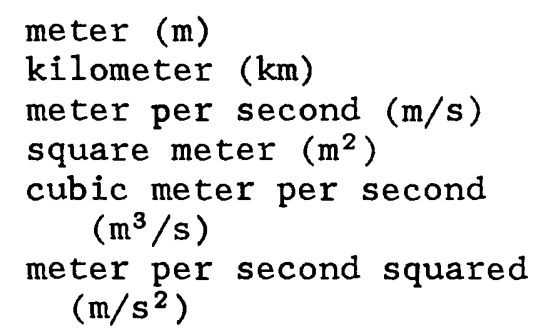

\section{ADDITIONAL ABBREVIATIONS and SYMBOLS}

\author{
${ }^{\circ} \mathrm{C}=$ degree Celsius \\ $\mu \mathrm{g} / \mathrm{L}=$ microgram per 1iter \\ $\mu \mathrm{g} \mathrm{hr} / \mathrm{L}=$ microgram hour per liter
}

$$
\begin{aligned}
& \mu \mathrm{m}=\text { micrometer } \\
& \mathrm{mL}=\mathrm{milliliter} \\
& \mathrm{ft} / \mathrm{ft}=\text { foot per foot }
\end{aligned}
$$

$7 \mathrm{Q}, 10=7$-day, 10-year low flow: A low-flow frequency that is the lowest average rate of flow for 7 consecutive days to or below which streamflow can be expected to decline in 1 year out of 10, on the average (Hayes, 1978). 


\title{
MEASUREMENT OF REAFRATION COEFFICIENTS FOR SELECTED FLORIDA STREAMS
}

\author{
By Paul S. Hampson and John E. Coffin
}

\begin{abstract}
A total of 29 separate reaeration coefficient determinations were performed on 27 subreaches of 12 selected Florida streams between October 1981 and May 1985. Measurements performed prior to June 1984 were made using the peak and area methods with ethylene and propane as the tracer gases. Later measurements utilized the steady-state method with propane as the onIy tracer gas. The reaeration coefficients ranged from 1.07 to 45.9 days with a mean estimated probable error of \pm 16.7 percent. Ten predictive equations (compiled from the literature) were also evaluated using the measured coefficients. The most representative equation was one of the energy dissipation type with a standard error of 60.3 percent. Seven of the 10 predictive additional equations were modified using the measured coefficients and nonlinear-regression techniques. The most accurate of the developed equations was also of the energy dissipation form and had a standard error of 54.9 percent. For 5 of the 13 subreaches in which both ethylene and propane were used, the ethylene data resulted in substantially larger reaeration coefficient values which were rejected. In these reaches, ethylene concentrations were probably significantly affected by one or more electrophilic addition reactions known to occur in aqueous media.
\end{abstract}

\section{INTRODUCTION}

\section{Background}

An adequate dissolved oxygen supply is critical to the environmental quality of a stream. Reaeration, the absorption of atmospheric oxygen at the air-water interface, is one of the principal processes by which streams obtain dissolved oxygen required to suppress the deleterious effects of organic and inorganic oxygen-demanding substances. Thus, an accurate knowledge of stream reaeration capacities is a principal key to successful stream-quality management because the degree of waste treatment and discharge volume limitations are largely determined by the reaeration capacity of the receiving stream. Simply, streams that receive more oxygen demanding substances than can be assimilated by available oxygen will undergo severe environmental stress. To prevent oxygen depletion in natural streams, resources managers now establish optimum waste-load allocations for the Nation's streams. Methods for the accurate and dependable evaluation of stream reaeration capacities are a valuable tool in the determination of waste-load allocations and waste-treatment requirements. 
The reaeration coefficient is a first order rate constant in the basic gas absorption equation for water which was first applied to reaeration problems in the classic work of streeter and Phelps (1925). In a natural stream, the reaeration coefficient is a general measure of gas exchange capacity and includes the effects of molecular diffusion and mechanical dispersion (mixing). Although the reaeration coefficient is generally reported as a single constant, the single value actually represents an average of many individual values within the stream reach (Tsivoglou, 1967).

A variety of methods for the determination of stream reaeration coefficients have been proposed. These include the dissolved oxygen balance technique, the disturbed equilibrium method, gas tracer techniques, and various predictive mathematical models. All of these methods have limitations ranging from sometimes unreliable and inaccurate results from the predictive models to the expense and difficulty involved in gas tracer measurements (Bennett and Rathbun, 1972). Since its development by Tsivoglou and others, (1965), however, the gas tracer method has been considered the most promising and reliable method. This method has gained further acceptance since the introduction by Rathbun and others (1978) of a modification of the method which uses hydrocarbon gas tracers.

As the agency responsible for establishing waste-load allocations for the State's municipal and industrial discharges, the Florida Department of Environmental Regulation has recognized the need for additional fieldverified estimates of the reaeration capacities of Florida's streams. Many current waste-load allocations have been established without benefit of site-specific data. Direct measurements of reaeration coefficients have not been routinely performed on many Florida streams and the predictive equations used for estimation commonly have been neither evaluated nor validated. The site-specific data collection and evaluation of the reaeration capacities of Florida streams determined during this investigation and comparison with other methods are intended to supplement current waste-load management procedures.

\section{Purpose and Scope}

The purpose of this report is to present the results of dye dispersiondilution and hydrocarbon gas tracer measurements performed on 12 Florida streams (figs. 1 and 2) and, to compare the results with values based on 10 commonly used predictive equations for the stream reaeration coefficient. The investigation was conducted by the U.S. Geological Survey in cooperation with the Florida Department of Environmental Regulation between October 1981 and May 1985. During the study, a total of 29 separate reaeration coefficient determinations were made on 27 different subreaches of streams by using 3 gas-tracer techniques. Streams were chosen to provide a representative range of streamflow conditions prevalent in the state of Florida to enable a broad evaluation of the applicability and validity of various predictive equations. Several of the selected streams also were of special interest to the Florida Department of Environmental Regulation. Emphasis was also placed on the performance of reaeration coefficient determinations during conditions of low flow to provide coefficient estimates representative of hypothetical worst-case scenarios. The results of this investigation will be useful in the implementation of future waste-load allocations standards for Florida streams. 


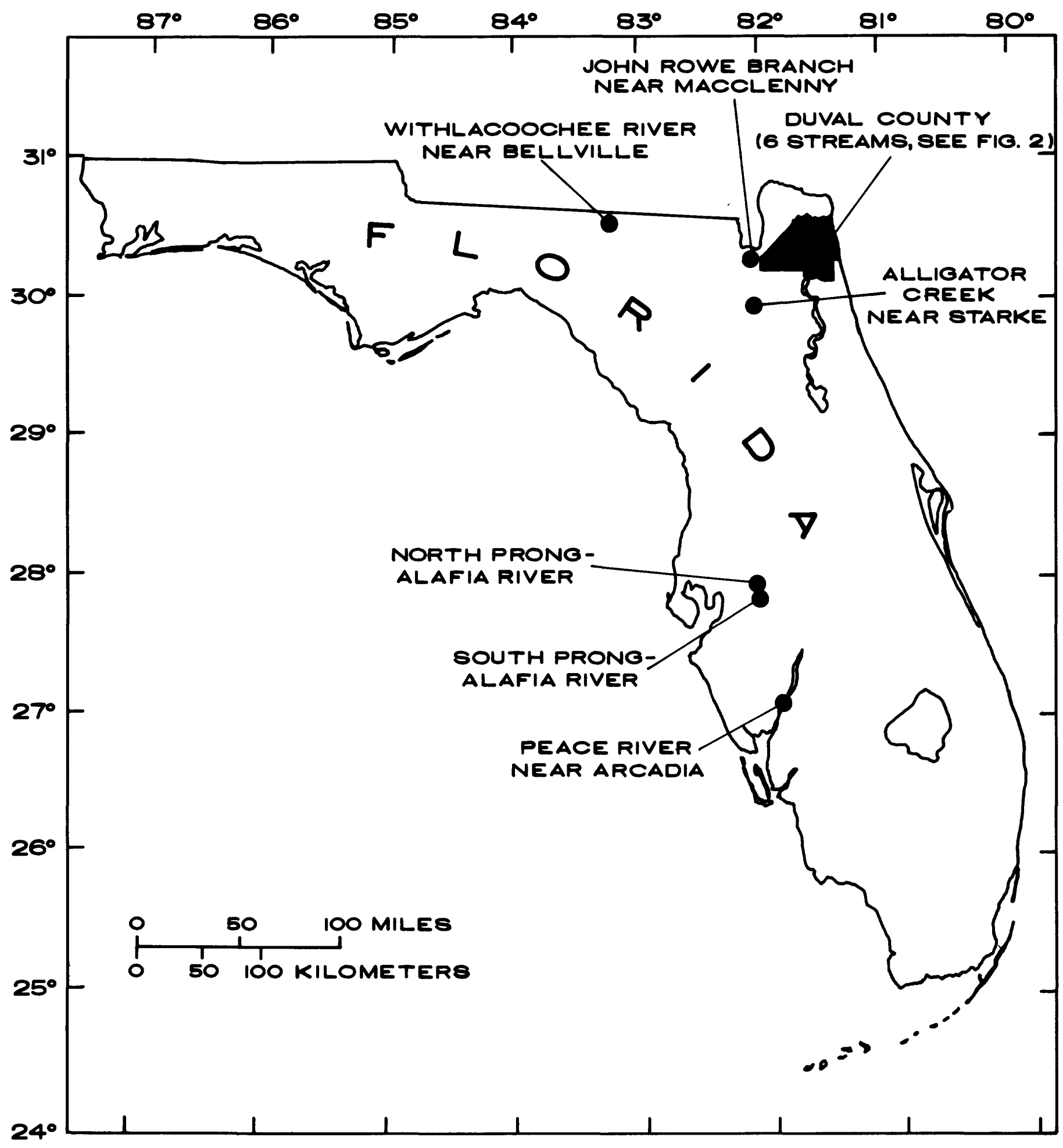

Figure 1.--Location of stream sites. 


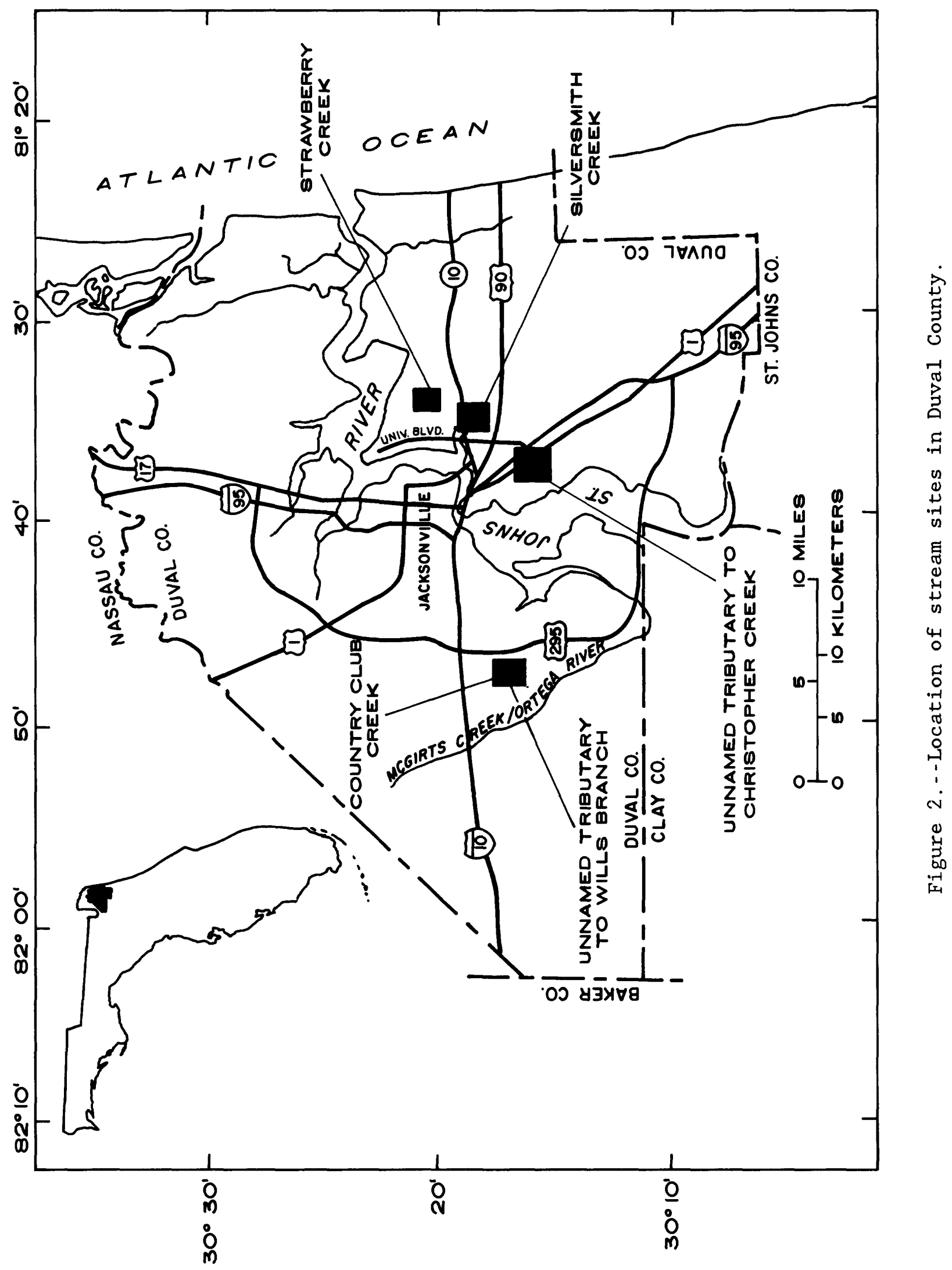




\section{HYDROCARBON GAS TRACER TECHNIQUES}

During the investigation, three gas-tracer techniques of stream reaeration coefficient determination were utilized. Measurements performed prior to June 1984 utilized the peak and area methods described by Rathbun and Grant (1978) which, at that time, were the only documented hydrocarbon gas methods. These two methods are grouped together because their field procedures are identical. The peak and area methods differ in the data and formulae used for calculation although both may be obtained from a single test. In 1983, the steady-state method was developed and documented by Yotsukura and others (1983). Because of inherent cost advantages and simplification of some field procedures, the steady-state method was utilized for later measurements. The steady-state method differs only slightly in performance and calculation from the peak and area methods.

The hydrocarbon gas tracer technique was developed by Rathbun and others (1975). The technique uses low-molecular weight hydrocarbon gases, ethylene or propane, as tracer gases and rhodamine-WT dye as a dispersiondilution tracer. Use of the dye permits adjustment of the gas concentrations for the effects of dispersion and dilution that might result from increased streamflow. Quantities of the tracer gas and rhodamine-WT dye are injected into a stream cross section upstream of the segment to be studied. Samples are collected at points downstream and concentrations of gas and dye tracers are determined by laboratory analysis. From these concentrations, the desorption coefficient can be calculated. The desorption coefficient is a first-order rate constant in the expression for the rate of gas loss to the atmosphere.

Once the desorption coefficient of the tracer gas has been determined, the stream reaeration coefficient can be calculated using an appropriate conversion factor. Conversion factors for ethylene and propane have been determined in a series of laboratory studies using stirring tanks. Details of the laboratory studies are described in Rathbun and others (1978). The resulting conversion equations are:

$$
\mathrm{K}_{\mathrm{r}}=1.15 \mathrm{~K}_{\mathrm{e}}
$$

where

$$
\begin{aligned}
& \mathrm{K}_{\mathrm{r}}=\text { reaeration coefficient and } \mathrm{K}_{\mathrm{e}}=\text { measured desorption coefficient } \\
& \text { for ethylene; and }
\end{aligned}
$$

$$
\mathrm{K}_{\mathrm{r}}=1.39 \mathrm{~K}_{\mathrm{p}}
$$

where

$$
\begin{gathered}
\mathrm{K}_{\mathrm{p}}=\text { measured desorption coefficient for propane. These conversion } \\
\text { factors were confirmed by Rainwater and Holley (1984). }
\end{gathered}
$$

Both the solubility of oxygen in water and the reaeration coefficient are functions of temperature, therefore, valid comparisons between coefficients can only be made between values adjusted to a specified reference water temperature. Reaeration coefficients presented in this report are referenced to $20^{\circ} \mathrm{C}$ using the relation developed by Elmore and West (1961);

$$
\mathrm{K}_{\mathrm{r} 20{ }^{\circ} \mathrm{C}}=\mathrm{K}_{\mathrm{r}}(1.0241)^{20-\mathrm{T}}
$$


where

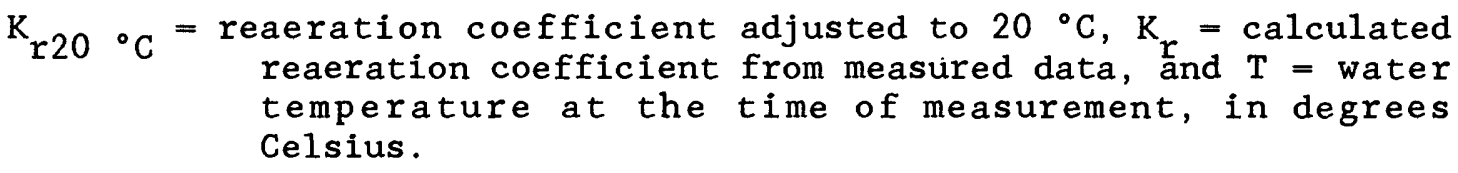

\section{Peak and Area Methods}

These separate analytical methods for the calculation of desorption coefficients as described in Rathbun and Grant (1978) are generally grouped together because of their similarity. Both employ short-duration injections of the gas tracer and measure transient gas concentrations. The "peak concentration" method, originally developed by Tsivoglou and others (1968), uses the dye tracer to indicate travel time and to correct the peak gas concentrations for dispersion. The "area" method uses the total mass of the tracer gas passing each sampling site to compute the desorption coefficient. Both techniques have been field tested and verified by Rathbun and Grant (1978) and Grant and Skavronek (1981).

Using the peak concentration method, the desorption coefficient is calculated as:

$$
\mathrm{K}_{\mathrm{T}}=\frac{1}{\left(t_{\mathrm{d}}-\mathrm{t}_{\mathrm{u}}\right)} \ln \frac{\mathrm{C}_{\mathrm{T}} / \mathrm{C}_{\mathrm{u}}}{\mathrm{C}_{\mathrm{T}_{\mathrm{d}}} / \mathrm{J} \cdot \mathrm{C}_{\mathrm{D}_{\mathrm{d}}}}
$$

where

$\mathrm{K}_{\mathrm{T}}=$ desorption coefficient for the tracer gas;

$\left(t_{d}-t_{u}\right)=$ the time of travel of the peak gas concentration, in hours;

1n = the natural logarithm to base e;

$\mathrm{C}_{\mathrm{T}}=$ peak concentration of the tracer gas, in micrograms per 1iter;

$C_{D}=$ peak concentration of dye, in micrograms per liter;

$J=$ the dye correction factor;

and $u$ and $d$ denote the upstream and downstream ends of the reach, respectively. The dye correction factor $J$ is necessary because of the nonconservative nature of the rhodamine-WT tracer and may be computed as:

$$
J=\frac{Q_{u} A}{Q_{d}^{A} d}
$$

where

$Q=$ discharge, in cubic feet per second;

$A=$ area under the dye concentration versus time curve, in microgram hours per liter;

and $u$ and $d$ again denote the upstream and downstream ends of the stream segment, respectively. 
The area method of analysis has as its basis the equation:

$$
K_{T}=\frac{1}{\left(t_{d}-t_{u}\right)} \ln \frac{A_{u}}{A_{d}}
$$

where

$$
\begin{aligned}
& A=\text { area under the gas concentration versus time curve, in microgram } \\
& \text { hours per liter; } \\
&\left(t_{d}-t_{u}\right)= \text { time of travel of the centroid of the gas tracer mass, in hours; } \\
& \text { and } u \text { and denote the upstream and downstream ends of the } \\
& \text { stream segment, respectively. }
\end{aligned}
$$

Equation 6 is valid only under conditions of steady flow. If discharges at the two sampling locations are unequal, the equation must be corrected and it becomes:

$$
K_{T}=\frac{1}{\left(t_{d}-t_{u}\right)} \ln \frac{A_{u} Q_{u}}{A_{d} Q_{d}}
$$

\section{Steady-State Method}

The steady-state method was developed by Yotsukura and others (1983). In this method, the gas tracer is injected continuously at a constant rate sufficiently long to produce steady-state gas concentrations at downstream cross sections following complete mixing. Gas concentrations obtained under steady-state, uniformly mixed conditions require no correction for dispersion and yield a more direct determination of gas desorption than measurements performed under transient conditions (Yotsukura and others, 1983).

The steady-state analysis has as its basis the equation:

$$
K_{T}=\frac{1}{\left(t_{d}-t_{u}\right)} \ln \frac{\bar{C}_{u} \bar{Q}_{u}}{\bar{C}_{d} \bar{Q}_{d}}
$$

where

$$
\begin{array}{r}
\left(t_{d}-t_{u}\right)=\text { the time of travel of the dye plume centroids, and the } \\
\text { over bars denote mean values for steady state gas } \\
\text { concentrations and discharges during the measurements. }
\end{array}
$$




\title{
METHODS OF INVESTIGATION
}

\author{
Field Data Collection
}

Hydrocarbon-gas tracer methods entail the simultaneous injection of gas and dye tracers into the stream. For each study subreach, the quantities of dye and gas required for satisfactory results were first estimated using methods outlined by Rathbun (1979). The estimations take into consideration such factors as streamflow, reach length, and estimated reaeration rates. Following injection, samples for gas and dye analysis were collected at two or more downstream locations. Discharge and water-temperature measurements were performed at each location in conjunction with sample collection.

Injection of propane and ethylene gases into the stream was accomplished by the use of portable gas tanks fitted with pressure regulators and rotameters for the control and monitoring of the flow rate. The gases were routed from the tanks and regulators with clear plastic tubing to porous tile diffusers placed on the streambed. The diffusers have a pore size of $2 \mu \mathrm{m}$ (micrometers). Rhodamine-WT dye solution was injected at the water surface either by pumping from containers with flow calibrated pumps or by addition of a premeasured dye slug to the stream cross section.

Samples for gas and dye analysis were collected in $40 \mathrm{~mL}$ (miliiliter) glass vials with polytetrafiuoroethylene sealed caps. Gas samples were collected following the guidelines of Rathbun (1979) for field-site processing including the addition to each sample of $1 \mathrm{~mL}$ of reagent grade formalin to inhibit biological degradation during storage. Gas samples which developed bubbles during storage or shipment were discarded. Dye samples were shielded from intense sunlight and kept relatively cool by storage in closed plastic coolers prior to analysis to prevent possible photodecomposition.

Discharge measurements were performed using Price AA or pygmy current meters at each sampling site. Standard U.S. Geological Survey stream gaging procedures as described by Buchanan and Somers (1969) were used in each measurement. The precision of each discharge measurement was estimated by the field personnel performing the measurement based upon conditions at the site. All of the measurement conditions determined during this study were rated either good ( \pm 5 percent) or fair ( \pm 8 percent). Water temperatures were taken at each sampling point using a calibrated thermometer accurate to $\pm 0.1^{\circ} \mathrm{C}$.

\section{Analytical Methods}

Analyses for propane and ethylene were performed at the U.S. Geological Survey National Water-Quality Laboratory-Atlanta, in Doraville, Ga., using the gas chromatographic methods of Shultz and others (1976). The propane and ethylene determinations are considered accurate to \pm 2 or 3 percent with a detection limit of about $0.1 \mu \mathrm{g} / \mathrm{L}$ (microgram per liter) (Feltz and Anthony, 1984).

Rhodamine-WT dye samples were analyzed at the U.S. Geological Survey offices in Tallahassee and Jacksonville, Fla., using the fluorometric procedures described by Wilson and others (1984). The dye concentration determinations performed during this study are estimated to be accurate to approximately \pm 2 percent. 


\section{Error Estimates}

The accuracy of any final calculated value for the reaeration coefficient is dependent upon the precision with which the experimentally determined quantities can be measured. In the present case, the magnitude of some measurement errors, such as those connected with actual streamflow conditions are substantially beyond the control of the experimenter. In an attempt to estimate the reliability of the values presented, all reaeration coefficients in this report are presented plus or minus ( \pm ) an estimated probable error. The theory and general procedures used for estimation are given in Appendix 1 . The estimates were computed using a 2 percent standard relative error ( 100 times standard deviation divided by the mean) for hydrocarbon gas analyses and for Rhodamine-WT dye determinations.

Al1 travel times were assumed accurate to 0.10 hour. The reaeration coefficient values ranged from 1.07 to 45.9 days $^{-1}$ with an estimated mean probable error of \pm 16.7 percent. The estimated probable errors for the determinations ranged from 2.7 to 82 percent. The probable error estimates should not be considered rigorous but are intended to reflect the relative precision and reliability of the individual values presented.

\section{Peak and Area Methods}

Use of the peak and area methods of computation results in two different reaeration coefficient values for each gas as well as two separate estimates of the probable error. The values presented as $\mathrm{K}$ for propane and $\mathrm{K}$ for ethylene are weighted means of the values given by the two methods and are reported with the probable error estimate of the more precise determination. Values given by the peak and area methods were weighted relative to each other on the basis of their estimated precisions to compute the final mean value for each gas. Likewise, where applicable, the final $\mathrm{K}$ values are weighted means for the final $K_{\text {p }}$ and $K_{e}$ values reported with the estimated probable error of the more preclse computation.

For five subreaches in which both propane and ethylene gases were utilized, the ethylene values were rejected for the final determination of $\mathrm{K}_{r}$. This occurred for subreach $\mathrm{A}$ of $\mathrm{John}$ Rowe Branch and subreaches $\mathrm{B}, \mathrm{C}$, $E$, and $F$ of McGirts Creek-Ortega River, all of which yielded much higher coefficient values for ethylene. In these cases, the lower and more conservative propane value is reported as $K_{k}$. With the exception of subreach B of McGirts Creek-Ortega River, all of these reaches were impacted by actively discharging wastewater treatment facilities at the time of measurement. The possibility of some type of discharge into subreach $B$ of McGirts Creek-Ortega River cannot be discounted, even though it was not observed. Ethylene coefficients were rejected or retained on the basis of a Student's t statistic computed using the reaeration coefficient values and the estimated standard deviations. A 95 percent or greater probability of significant difference based on this statistic was used as the rejection criteria. Probabilities for the values actually rejected were all in excess of 97 percent. 
The significantly greater values for ethylene in these reaches probably result from the greater reactivity of ethylene gas relative to propane. The greater reactivity results from the unsaturated carbon-to-carbon double bond of the ethylene molecule which renders it more susceptible to electrophilic and free-radical addition reactions. In aqueous media, such as the natural waters considered in this report, the most probable reactions are, in order of thermodynamic favorability: halogen addition (for example, of chlorine), halohydrin formation (addition of chlorine and water), acid-catalyzed addition of water, and hydrogen halide addition (for example, of hydrogen chloride). An indepth discussion of ethylene chemistry is beyond the scope of this study, however, ethylene can be expected to be reactive in media containing chlorine or a substantial source of acidity. Both of these conditions might be expected downstream from certain wastewater treatment facilities.

\section{Steady-State Method}

The relative error of propane gas concentrations used in the steadystate method was computed from the concentrations of the samples collected. A minimum of five samples was used to compute the means and standard deviations of these concentrations. Discharge measurement precision was estimated by field personnel conducting the measurements based upon site conditions and ranged from 5 to 8 percent. 


\section{REAERATION COEFFICIENT MEASUREMENTS}

The results presented in this section have been broadly divided into two groups based upon the different methodologies utilized during the study. Reaeration coefficients determined for the first six streams presented were measured with the peak and area methods and the last six using the steadystate method.

Data presented for each stream include a location map, hydraulic data, traveltime-distance relations for the leading edges, peaks, and trailing edges of dye clouds, and where applicable, concentration-time curves for dye and hydrocarbon gases. The concentration-time figures also give peak concentrations, centroid time, areas, and standard deviations for the clouds. The standard deviations can be used as a measure of the longitudinal dispersion of the dye or gas clouds. Distances between sampling points and subreach slopes were measured from U.S. Geological Survey 7.5 minute topographic maps. Mean cross-sectional areas were calculated by dividing the mean discharge for each subreach by the mean velocity as determined from the measured distances and times of travel. Areas and centroids, presented where applicable, were computed using the trapezoidal method. For the purposes of illustration only, the leading and trailing edges of dye clouds as shown in the following figures represent times corresponding to 10 percent of the peak concentration at the sampling point. These data are presented to illustrate the longitudinal dispersion of the dye cloud and do not represent points used for the computation of dye cloud statistics.

In addition to the above data, low-flow data and discharges at the time of measurement are presented for nearby long-term stations. The low-flow frequencies in the form of 7-day, 10-year low flows $(7 Q, 10)$ are from Hughes (1981). The 7Q,10 is the lowest average rate of flow for 7 consecutive days to or below which streamflow can be expected to decline in one year out of ten, on the average (Hayes, 1978). These data are intended only to give a general notion of how actual streamflow conditions at the time of measurement might compare with historical low-flow conditions.

\section{Peak and Area Methods}

Determinations of reaeration coefficients prior to June 1984 were performed using the peak and area methods described by Rathbun and Grant (1978). These measurements were performed on subreaches of Alligator Creek near Starke, John Rowe Branch near Macclenny, McGirts Creek-Ortega River at Jacksonville, Country Club Creek at Jacksonville, an unnamed tributary to Wills Branch at Jacksonville, and the Peace River near Arcadia. For the majority of measurements, two hydrocarbon gases, propane and ethylene were used. Measurements performed at Country Club Creek on December 7, 1983, and at the unnamed tributary to Wills Branch on December 8, 1983, however, used only propane and all measurements on the Peace River used only ethylene. 


\section{Alligator Creek near Starke}

The test reach on Alligator Creek (fig. 3) is located south of the city of Starke, starting about 150 feet downstream from the wastewater treatment plant outfall. The streambed is composed primarily of soft sand and appears to have been channelized, having very few meanders. Stream water was clear indicating a relative absence of tannins and lignins frequently found in many Florida streams. The study was performed over two subreaches, $A$ and $B$, on December 8, 1981. Water temperature was $13.0^{\circ} \mathrm{C}$. The nearest long-term station for which low-flow frequencies were available for comparison was the Santa Fe River near Graham. Discharge for the Santa Fe River near Graham on the day of the study was $3.9 \mathrm{ft}^{3} / \mathrm{s}$ (cubic feet per second). The 7Q,10 for Graham is computed to be $0.17 \mathrm{ft}^{3} / \mathrm{s}$.

Figure 4 illustrates the time of trave1 of the leading edge, peak, and trailing edge of the dye cloud from the injection point to the downstream sample points. Figures 4 and 5 show time series data for dye and for propane and ethylene concentrations at sampling points 1, 2, and 3, respectively. Reaeration coefficients computed from these data are given below. No significant differences on the basis of the $t$ test explained earlier were observed between the values given by ethylene and propane, despite the discharge of the wastewater treatment facility.

\begin{tabular}{lcccc}
\hline Subreach & $\begin{array}{c}\text { Sampling } \\
\text { points }\end{array}$ & $\begin{array}{c}\mathrm{K}_{\mathrm{p}} \\
\text { (days }^{-1} \text { ) }\end{array}$ & $\begin{array}{c}\mathrm{K}_{\mathrm{e}} \\
\text { (days }^{-1} \text { ) }\end{array}$ & $\begin{array}{c}\mathrm{K}_{\mathrm{r}} \\
\text { (days }^{-1} \text { ) }\end{array}$ \\
\hline
\end{tabular}

$\begin{array}{llllll}\mathrm{A} & 1 \text { to } 2 & 4.82 \pm 2.08 & 3.71 \pm 1.70 & 4.16 \pm 1.70 \\ \mathrm{~B} & 2 \text { to } 3 & 3.37 \pm .88 & 4.25 \pm .74 & 3.89 \pm .74\end{array}$




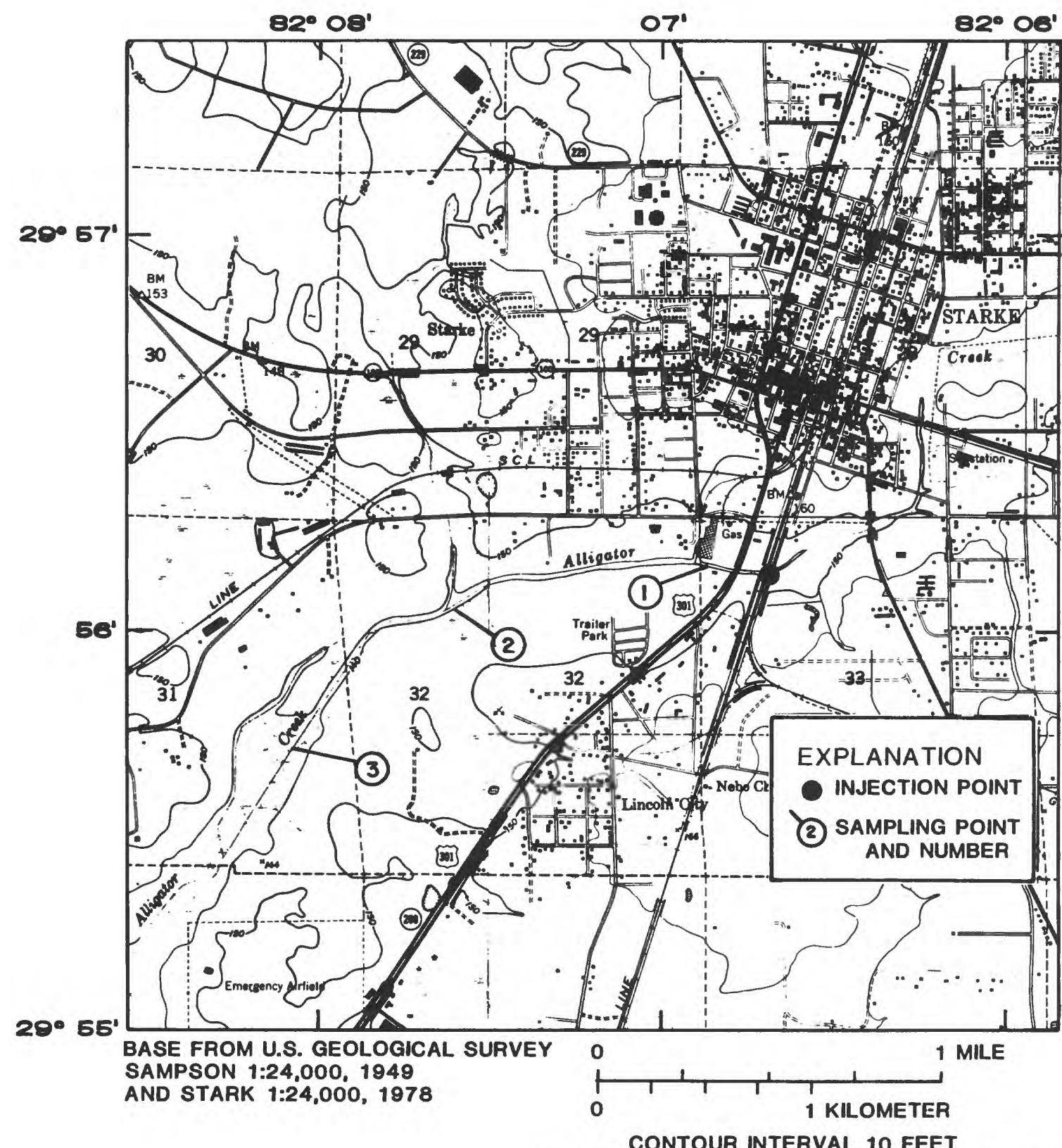

NATIONAL GEODETIC VERTICAL DATUM OF 1928

\begin{tabular}{|c|c|c|c|c|c|c|c|c|}
\hline Subreach & Date & $\begin{array}{l}\text { Length } \\
\text { (feet) }\end{array}$ & $\begin{array}{l}\text { Mean } \\
\text { width } \\
\text { (feet) }\end{array}$ & $\begin{array}{l}\text { Mean cross- } \\
\text { sectional } \\
\text { area (square } \\
\text { feet) }\end{array}$ & $\begin{array}{l}\text { Mean } \\
\text { slope } \\
\text { (foot per } \\
\text { foot) }\end{array}$ & $\begin{array}{l}\text { Upstream } \\
\text { discharge } \\
\text { (cubic feet } \\
\text { per second) }\end{array}$ & $\begin{array}{l}\text { Downstream } \\
\text { discharge } \\
\text { (cubic feet } \\
\text { per second) }\end{array}$ & $\begin{array}{c}\text { Time } \\
\text { of } \\
\text { travel } \\
\text { (hours) }\end{array}$ \\
\hline $\begin{array}{l}A-1 \text { to } 2 \\
B=2 \text { to } 3\end{array}$ & $12 / 08 / 81$ & 3,850 & 13.5 & 12.5 & 0.00106 & 7.70 & 9.96 & 1.52 \\
\hline
\end{tabular}

Figure 3.--Location and hydraulic data for Alligator Creek near Starke. 

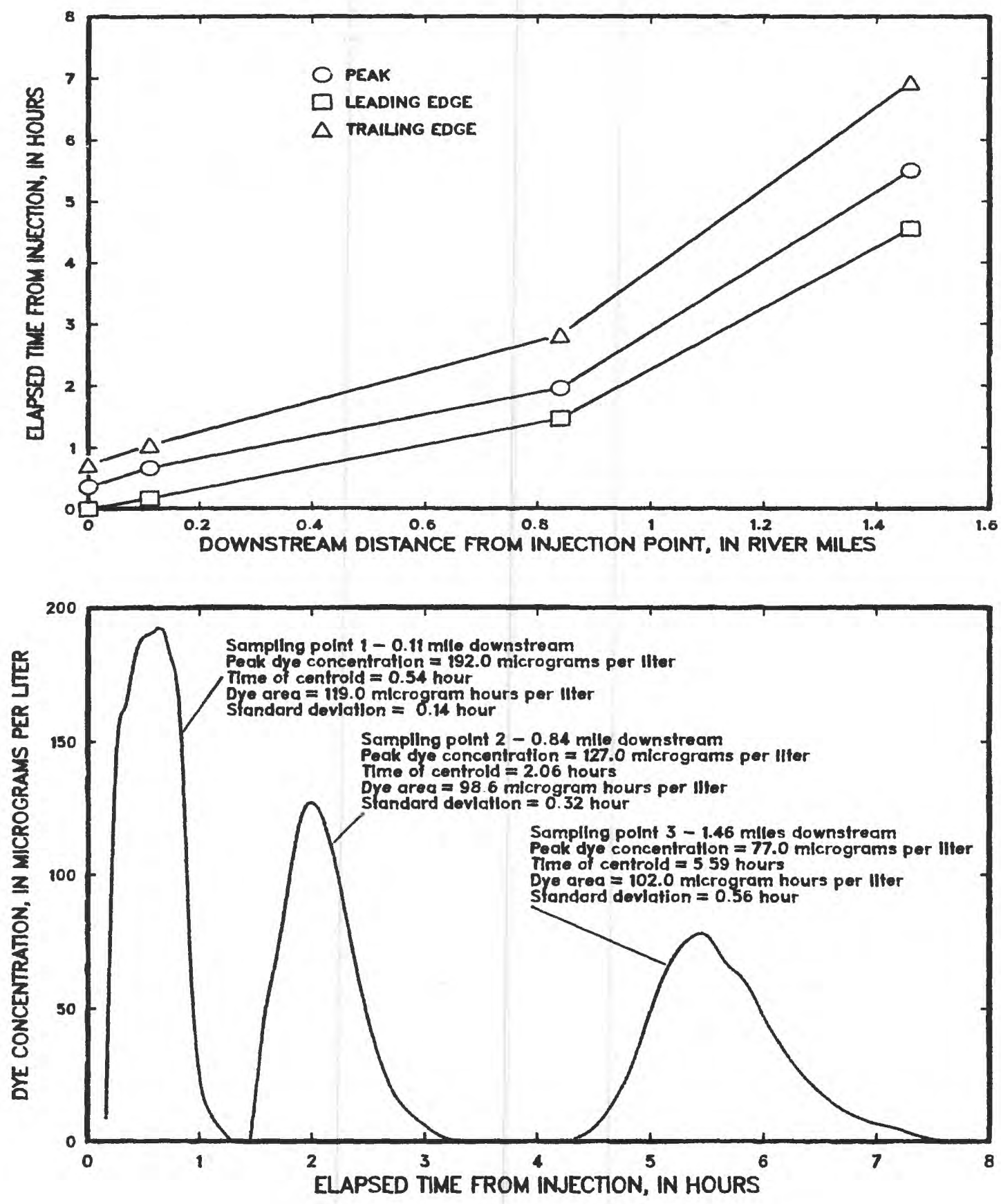

Figure 4.--Traveltime-distance and dye concentration-time curves for Alligator Creek near Starke. 


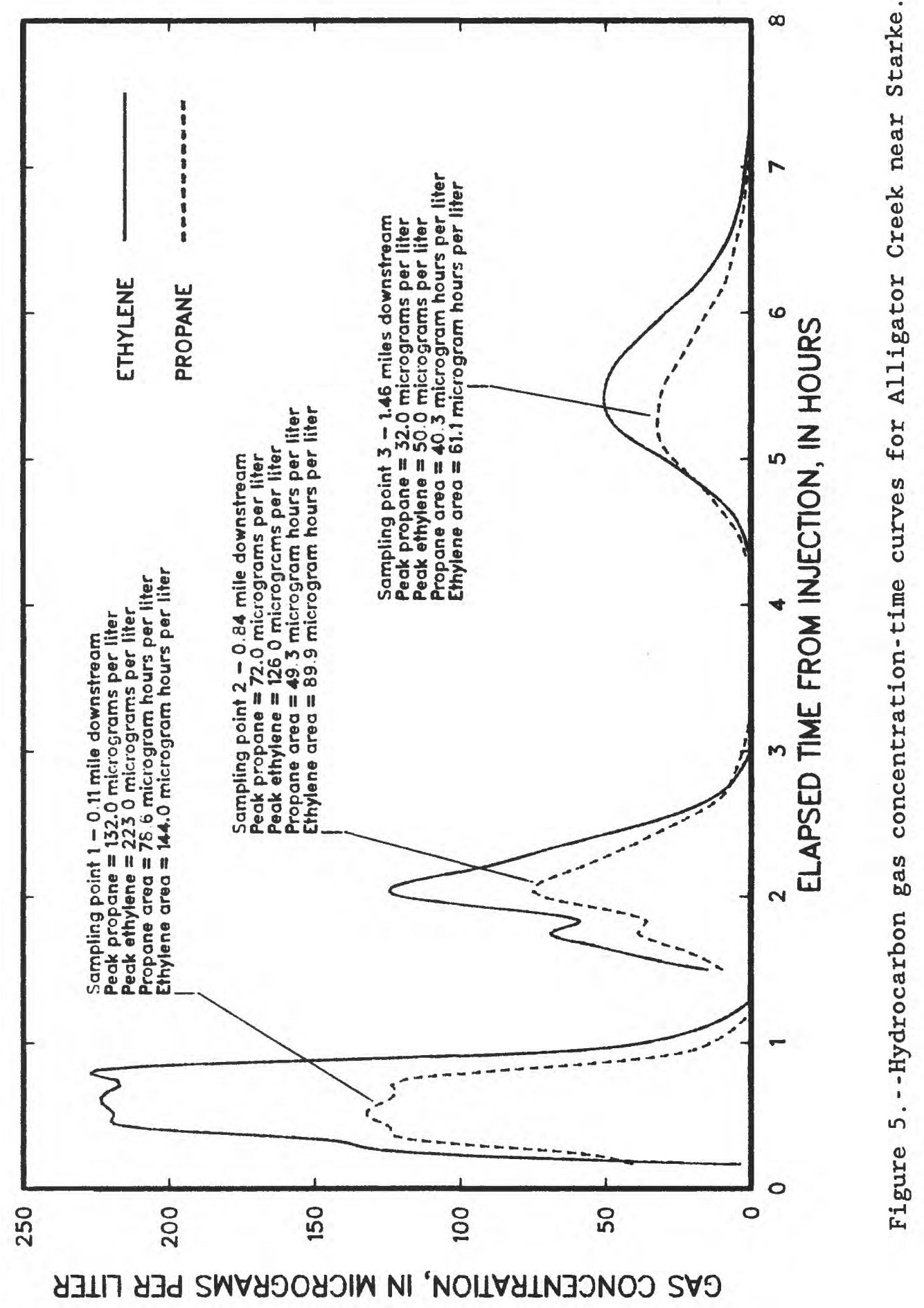


John Rowe Branch near Macclenny

John Rowe Branch (fig. 6) is located south of the Northeast Florida State Hospital, off Highway 121, and flows west to the South Prong of the St. Marys River. The study reach starts about 150 feet downstream of the hospital wastewater treatment plant outfall. Channel conditions to the east of Highway 121 are poorly defined because of heavy vegetation and are only slightly better defined to the west. The bottom is extremely soft at the upstream section becoming sandy downstream. The study was performed over only one subreach on May 11, 1982. Water temperature was $28.0^{\circ} \mathrm{C}$. The nearest long-term station for which low-flow frequencies were available was the St. Marys River near Macclenny. Discharge for the St. Marys River near Macclenny on the day of the study was $139 \mathrm{ft}^{3} / \mathrm{s}$. The $7 \mathrm{Q}, 10$ for Macclenny is computed to be $18.0 \mathrm{ft}^{3} / \mathrm{s}$.

Figure 7 illustrates the time of travel of the leading edge, peak, and trailing edge of the dye cloud from the injection point to the downstream sample points. Figures 7 and 8 show time series data of dye and of propane and ethylene concentrations at sampling points 1 and 2 . Reaeration coefficients computed from these data are given below. The reaeration coefficient values yielded by the ethylene measurements were significantly higher than the propane values and were rejected. The final value of $K_{r}$ reported is the lower, more conservative propane value.

\begin{tabular}{ccccc}
\hline Subreach & $\begin{array}{c}\text { Sampling } \\
\text { points }\end{array}$ & $\begin{array}{c}\mathrm{K}_{\mathrm{p}} \\
\text { (days }^{-1} \text { ) }\end{array}$ & $\begin{array}{c}\mathrm{K}_{\mathrm{e}} \\
\text { (days }^{-1} \text { ) }\end{array}$ & $\begin{array}{c}\mathrm{K}_{\mathrm{r}} \\
\text { (days }^{-1} \text { ) }\end{array}$ \\
\hline A & 1 to 2 & $3.83 \pm 0.65$ & $7.33 \pm 0.63$ & $3.83 \pm 0.65$
\end{tabular}




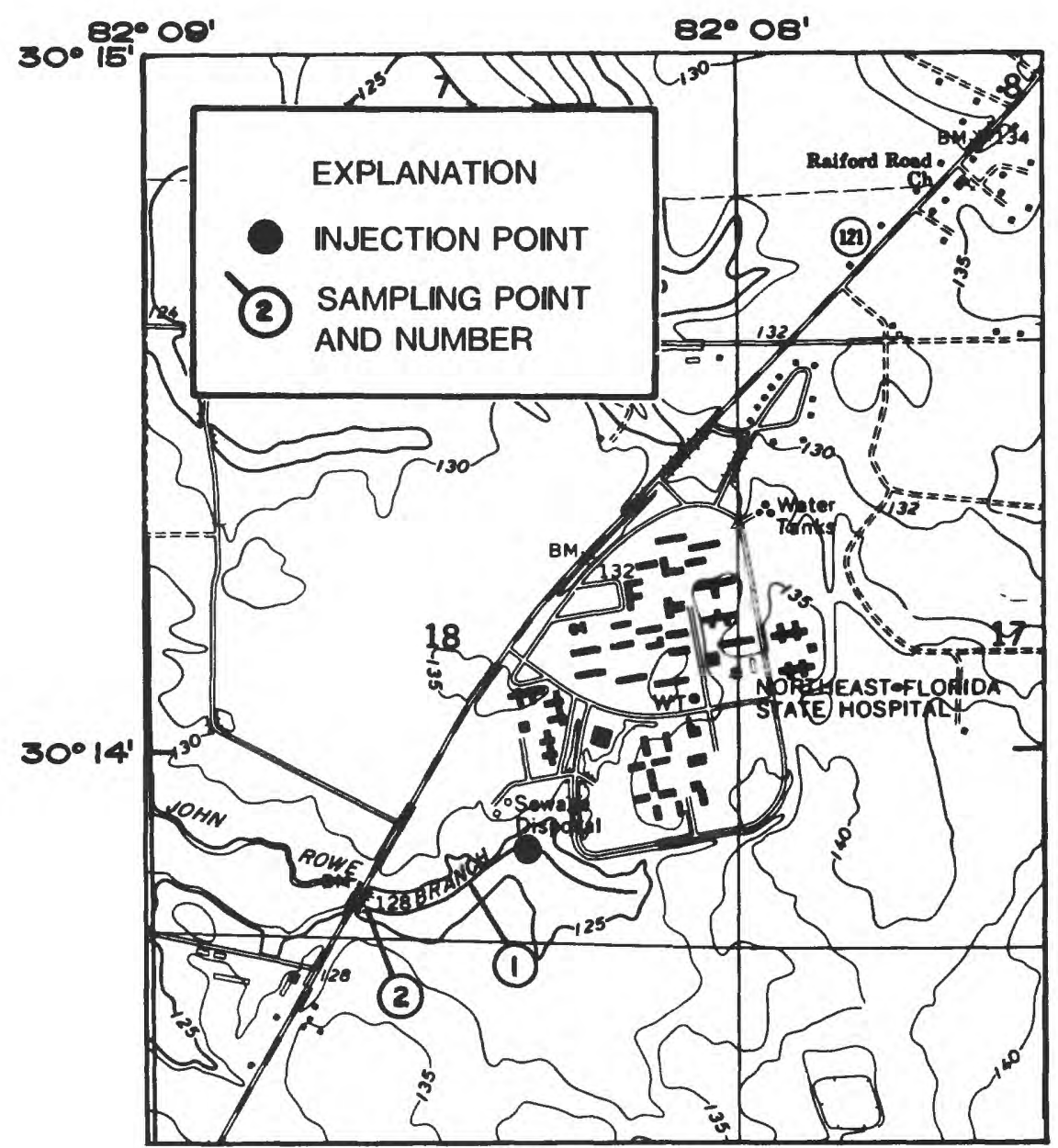

BASE FROM U.S. GEOLOGICAL SURVEY

MANNING 1:24,000, 1970

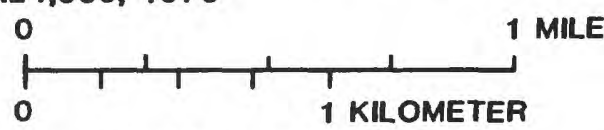

CONTOUR INTERVAL 5 FEET

NATIONAL GEODETIC VERTICAL DATUM OF 1929

\begin{tabular}{lcccccccc}
\hline Subreach & Date & $\begin{array}{c}\text { Length } \\
\text { (feet) }\end{array}$ & $\begin{array}{c}\text { Mean } \\
\text { width } \\
\text { (feet) }\end{array}$ & $\begin{array}{c}\text { Mean cross- } \\
\text { sectional } \\
\text { area (square } \\
\text { feet) }\end{array}$ & $\begin{array}{c}\text { Mean } \\
\text { slope } \\
\text { (foot per } \\
\text { foot) }\end{array}$ & $\begin{array}{c}\text { Upstream } \\
\text { discharge } \\
\text { (cubic feet } \\
\text { per second) }\end{array}$ & $\begin{array}{c}\text { Downstream } \\
\text { discharge } \\
\text { (cubic feet } \\
\text { per second) }\end{array}$ & $\begin{array}{c}\text { Time } \\
\text { of } \\
\text { travel } \\
\text { (hours) }\end{array}$ \\
\hline A- 1 to 2 & $05 / 11 / 82$ & 1,200 & 5.90 & 8.99 & 0.00333 & 0.90 & 0.90 & 3.33 \\
\hline
\end{tabular}

Figure 6.--Location of and hydraulic data for John Rowe Branch near Macclenny. 

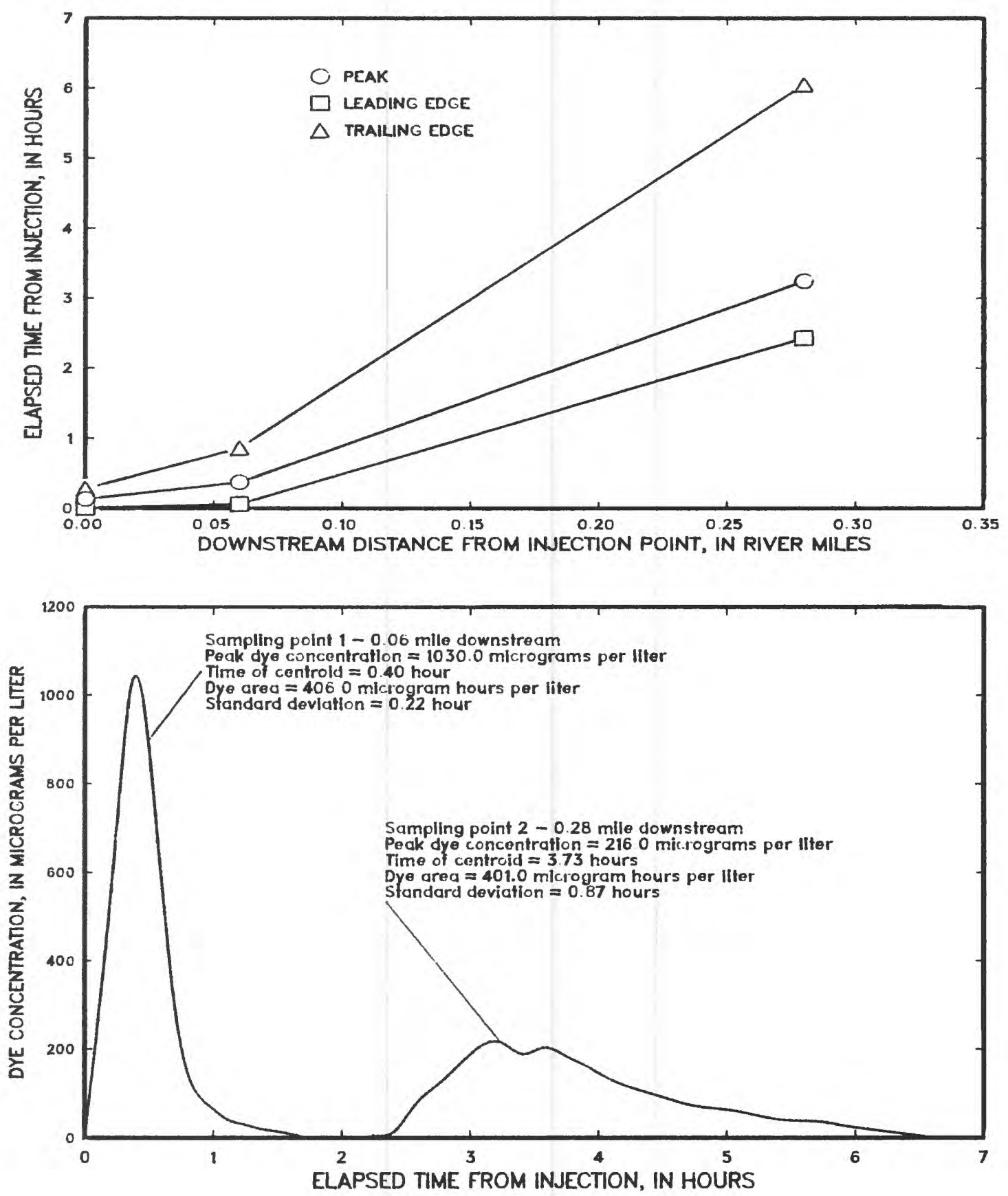

Figure 7.--Traveltime-distance and dye concentration-time curves for John Rowe Branch near Macclenny. 


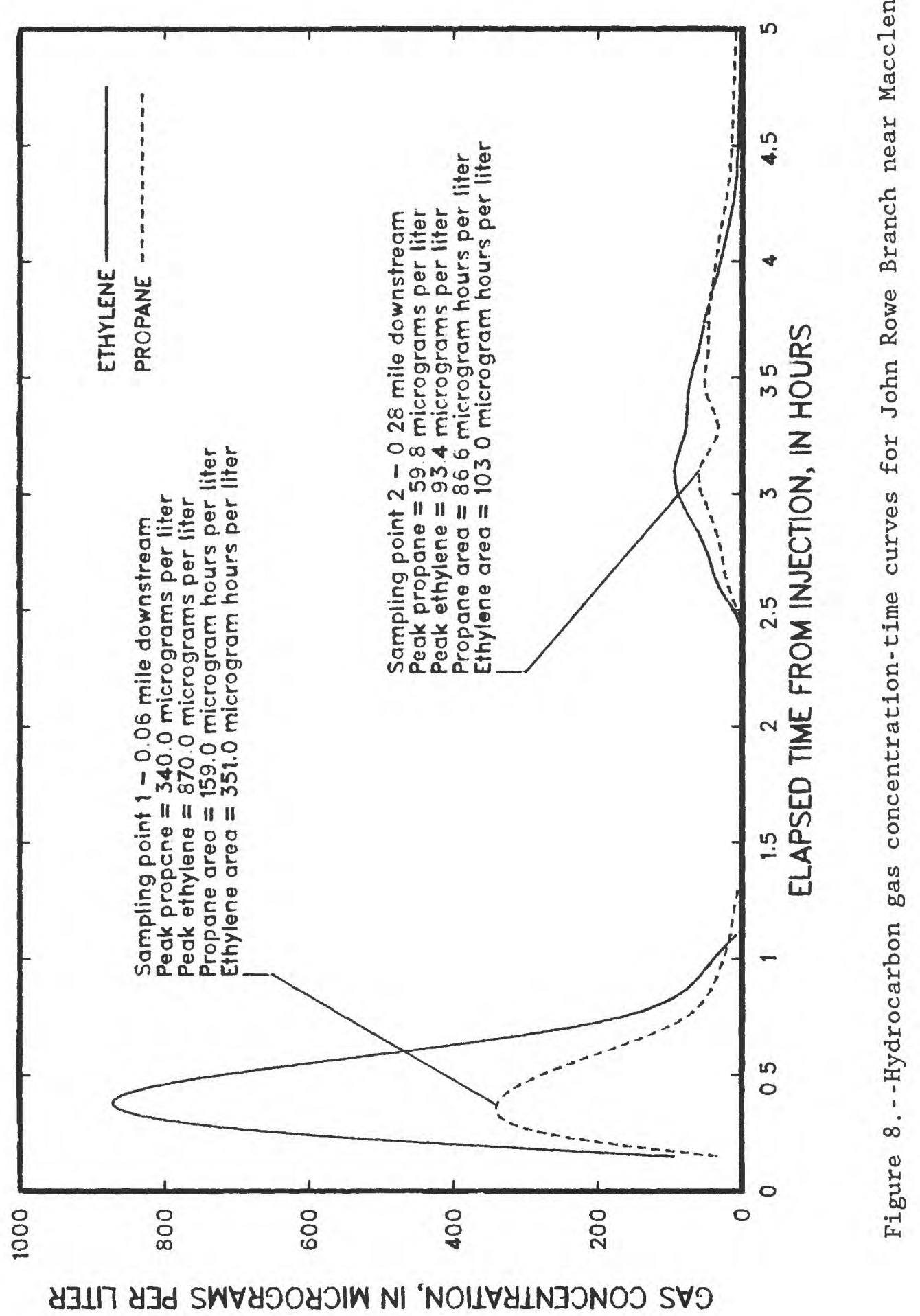




\section{McGirts Creek-Ortega River at Jacksonville}

Several reaches along the McGirts Creek and the Ortega River were studied from the headwaters at OLF Whitehouse Naval Air Station to northwest of Jacksonville to 118th Street in Jacksonville. The part of this stream above Highway 228 (Normandy Boulevard) is referred to on topographic maps as McGirts Creek. This part contains all of subreaches $A, B$, and $C$ and the upper part of subreach D. Below Highway 228 the stream is referred to as the Ortega River. Subreaches $E$ and $F$ and the lower part of subreach D fall within this part of the stream.

Subreach A of McGirts Creek-Ortega River from OLF Whitehouse to U.S. 90 (fig. 9) has a sand bottom underlain with clay that is exposed in some sections of the reach. A slight riffling effect and high velocities were noted where clay was exposed and the bottom rough with shallow depths of from 0.2 to 0.5 foot. Subreach A was measured on February 24, 1982. The water temperature during this measurement was $16.0{ }^{\circ} \mathrm{C}$. The time of trave 1 of the leading edge, peak, and trailing edge of the dye cloud from the point of injection to the downstream sample sites for subreach $A$ is given in figure 10. Figure 10 also presents pertinent data on the hydrocarbon gas concentrations.

Subreach B (fig. 11) is fully contained within subreach A and was measured on November 3, 1982. The water temperature during the measurement was $20.6{ }^{\circ} \mathrm{C}$. Figure 12 presents hydrocarbon gas data and the time of travel of the leading edge, peak, and trailing edge dye concentrations.

Subreach C (fig. 13) passes through a very swampy area with heavy vegetation and a poorly defined channel. Water color changes from clear above U.S. 90 to dark indicating high amounts of tannins and lignins from this swampy area. Velocities are sluggish due to the ponding of water. Subreach $C$ was measured on November 2, 1982. The water temperature at the time of measurement was $20.8{ }^{\circ} \mathrm{C}$. Time of travel and time series data for subreach $\mathrm{C}$ are shown in figure 14. Hydrocarbon gas data for subreach $\mathrm{C}$ are given below.

\begin{tabular}{cccccc}
\hline $\begin{array}{c}\text { Sampling } \\
\text { point }\end{array}$ & $\begin{array}{c}\text { Downstream } \\
\text { distance } \\
(\text { miles })\end{array}$ & $\begin{array}{c}\text { Peak } \\
\text { propane } \\
\text { concentration } \\
(\mu \mathrm{g} / \mathrm{L})\end{array}$ & $\begin{array}{c}\text { Peak } \\
\text { ethylene } \\
\text { concentration } \\
(\mu \mathrm{g} / \mathrm{L})\end{array}$ & $\begin{array}{c}\text { Propane } \\
\text { area } \\
(\mu \mathrm{g} h r / \mathrm{L})\end{array}$ & $\begin{array}{c}\text { Ethylene } \\
\text { area } \\
(\mu \mathrm{g} / \mathrm{hr} / \mathrm{L})\end{array}$ \\
\hline 5 & 0.28 & 239.0 & 739.0 & 55.1 & 158.8 \\
6 & .81 & 7.0 & 6.1 & 6.25 & 4.60
\end{tabular}




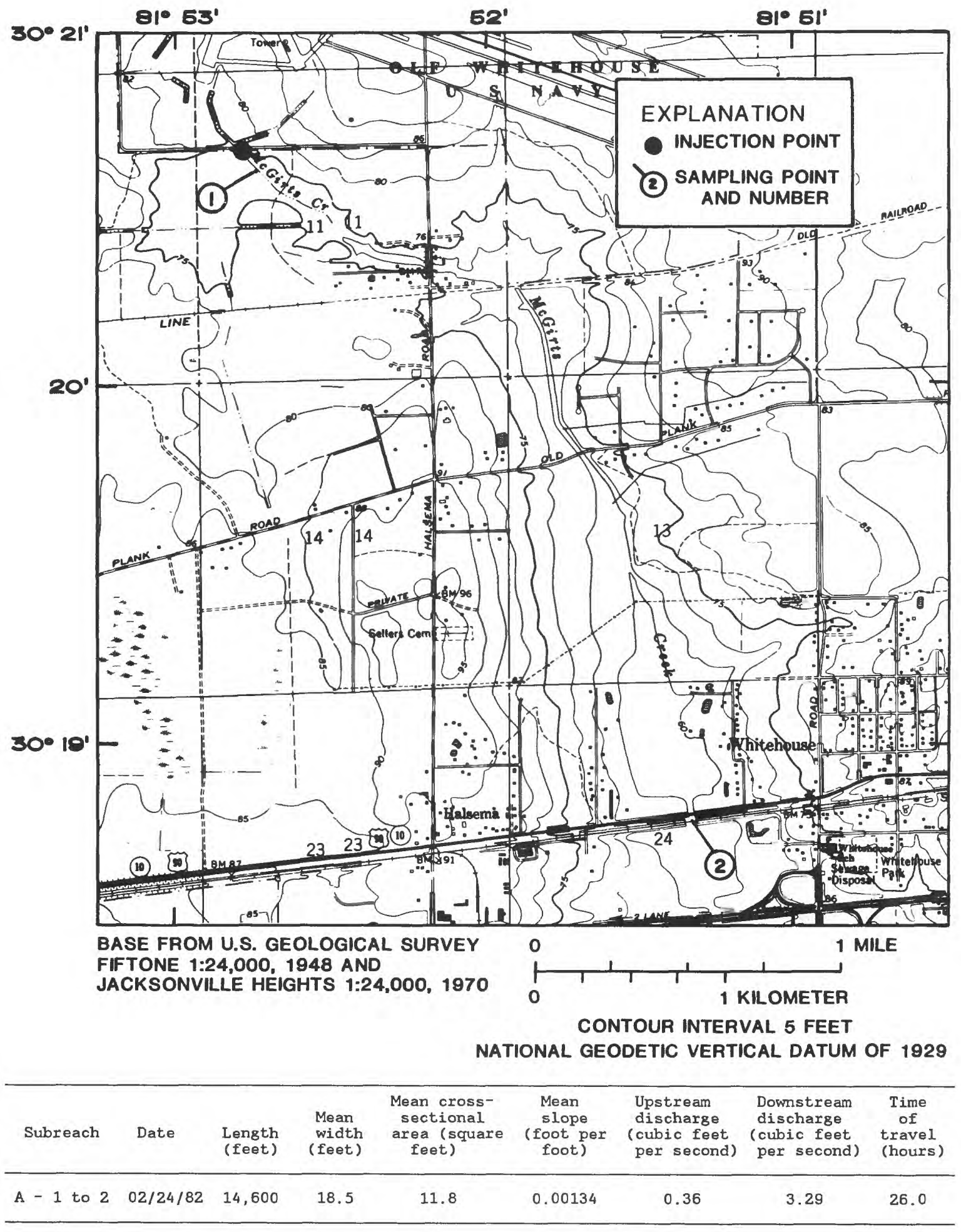

Figure 9.--Location of and hydraulic data for subreach A of McGirts CreekOrtega River at Jacksonville. 


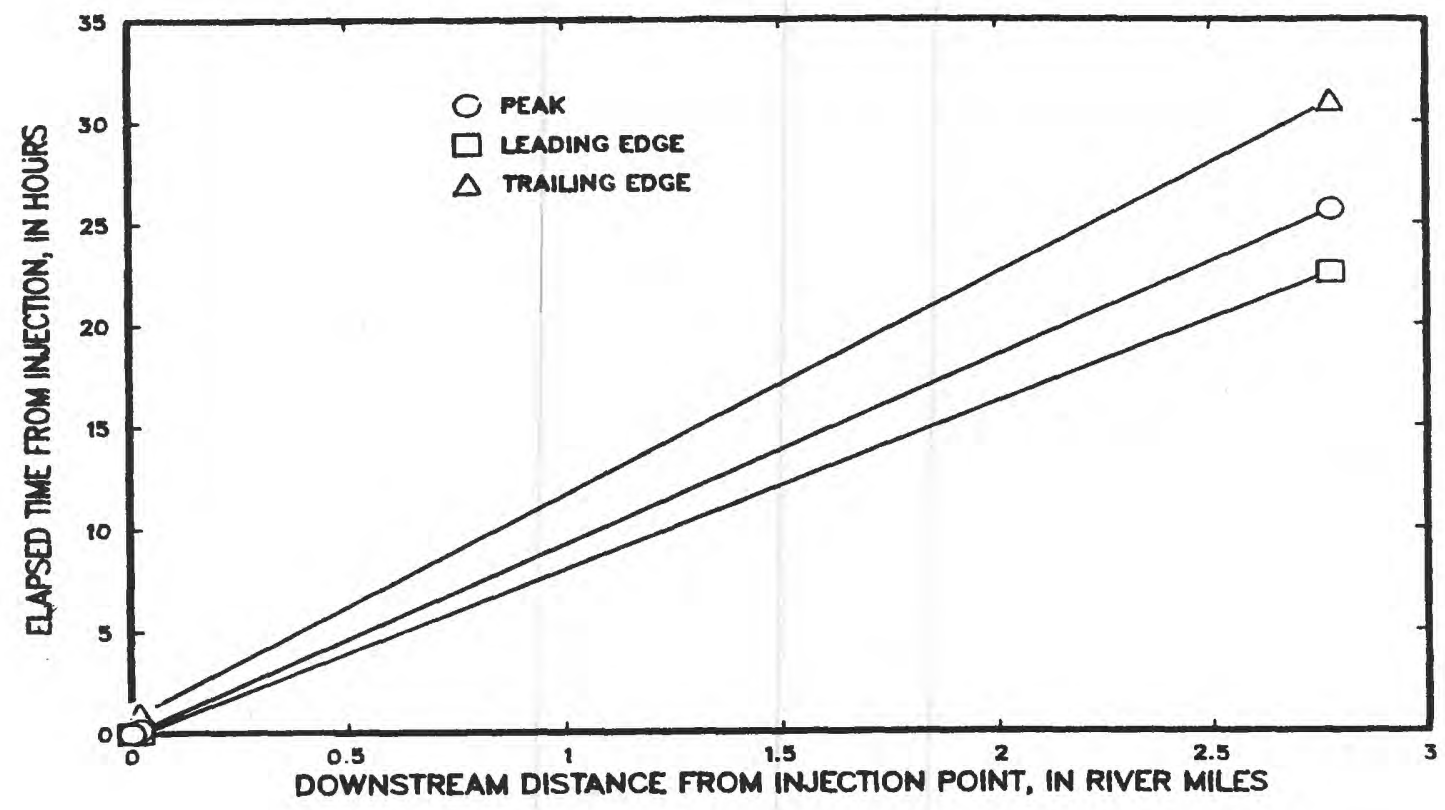

\begin{tabular}{|c|c|c|c|c|c|}
\hline $\begin{array}{l}\text { Sampling } \\
\text { point }\end{array}$ & $\begin{array}{l}\text { Downstream } \\
\text { distance } \\
\text { (miles) }\end{array}$ & $\begin{array}{l}\text { Peak dye } \\
\text { concentration } \\
\text { (micrograms } \\
\text { per liter) }\end{array}$ & $\begin{array}{l}\text { Dye area } \\
\text { (microgram- } \\
\text { hours per } \\
\text { liter) }\end{array}$ & $\begin{array}{l}\text { Time of } \\
\text { centroid } \\
\text { (hours) }\end{array}$ & $\begin{array}{l}\text { Dye cloud } \\
\text { standard } \\
\text { deviation } \\
\text { (hours) }\end{array}$ \\
\hline $\begin{array}{l}1 \\
2\end{array}$ & $\begin{array}{l}0.02 \\
2.78\end{array}$ & $\begin{array}{r}179.0 \\
1.10\end{array}$ & $\begin{array}{c}72.1 \\
4.48\end{array}$ & $\begin{array}{l}0.40 \\
26.4\end{array}$ & $\begin{array}{l}0.26 \\
1.81\end{array}$ \\
\hline $\begin{array}{l}\text { Sampling } \\
\text { point }\end{array}$ & $\begin{array}{l}\text { Downstream } \\
\text { distance } \\
\text { (miles) }\end{array}$ & $\begin{array}{c}\text { Peak } \\
\text { propane } \\
\text { concentration } \\
\text { (micrograms } \\
\text { per liter) }\end{array}$ & $\begin{array}{l}\text { Peak } \\
\text { ethylene } \\
\text { concentration } \\
\text { (microgram-hours } \\
\text { per liter) }\end{array}$ & $\begin{array}{c}\text { Propane } \\
\text { area } \\
\text { (microgram- } \\
\text { hours per } \\
\text { liter) }\end{array}$ & $\begin{array}{l}\text { Ethylene } \\
\text { area } \\
\text { (microgram- } \\
\text { hours per } \\
\text { liter) }\end{array}$ \\
\hline $\begin{array}{l}1 \\
2\end{array}$ & $\begin{array}{l}0.02 \\
2.78\end{array}$ & $\begin{array}{r}430.0 \\
.10\end{array}$ & $\begin{array}{r}770.0 \\
.16\end{array}$ & $\begin{array}{r}325.0 \\
.10\end{array}$ & $\begin{array}{r}612.0 \\
1.16\end{array}$ \\
\hline
\end{tabular}

Figure 10.--Traveltime-distance curves, dye concentration data, and hydrocarbon gas data for subreach A of McGirts Creek-Ortega River at Jacksonville. 


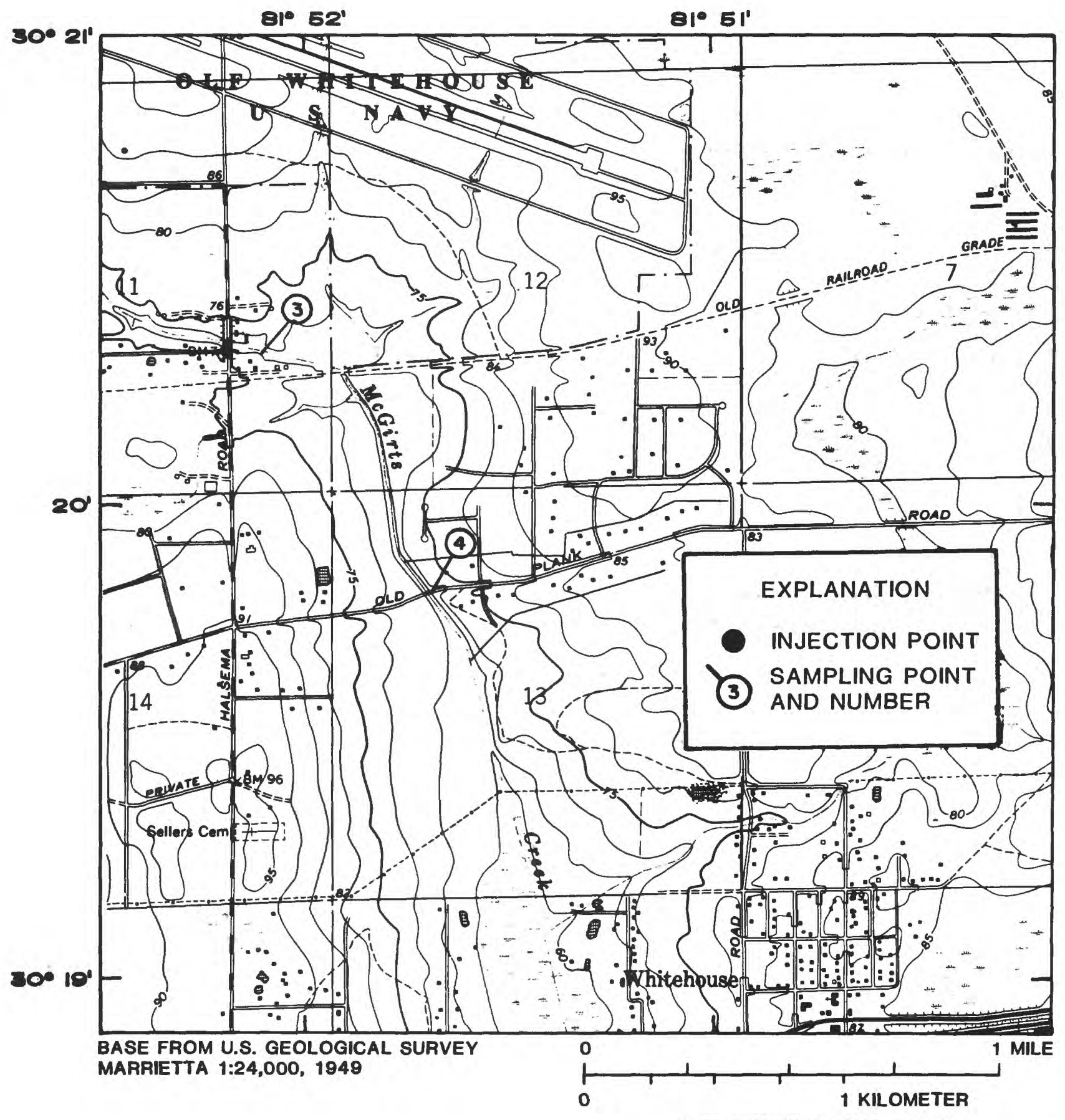

CONTOUR INTERVAL 5 FEET

NATIONAL GEODETIC VERTICAL DATUM OF 1929

\begin{tabular}{|c|c|c|c|c|c|c|c|c|}
\hline Subreach & Date & $\begin{array}{l}\text { Length } \\
\text { (feet) }\end{array}$ & $\begin{array}{l}\text { Mean } \\
\text { width } \\
\text { (feet) }\end{array}$ & $\begin{array}{l}\text { Mean cross- } \\
\text { sectional } \\
\text { area (square } \\
\text { feet) }\end{array}$ & $\begin{array}{l}\text { Mean } \\
\text { slope } \\
\text { (foot per } \\
\text { foot) }\end{array}$ & $\begin{array}{l}\text { Upstream } \\
\text { discharge } \\
\text { (cubic feet } \\
\text { per second) }\end{array}$ & $\begin{array}{l}\text { Downstream } \\
\text { discharge } \\
\text { (cubic feet } \\
\text { per second) }\end{array}$ & $\begin{array}{l}\text { Time } \\
\text { of } \\
\text { trave1 } \\
\text { (hours) }\end{array}$ \\
\hline$B-3$ to 4 & $11 / 03 / 82$ & 4,650 & 8.50 & 7.71 & 0.00255 & 1.18 & 1.41 & 7.63 \\
\hline
\end{tabular}

Figure 11.--Location of and hydraulic data for subreach B of McGirts Creek-Ortega River at Jacksonville. 


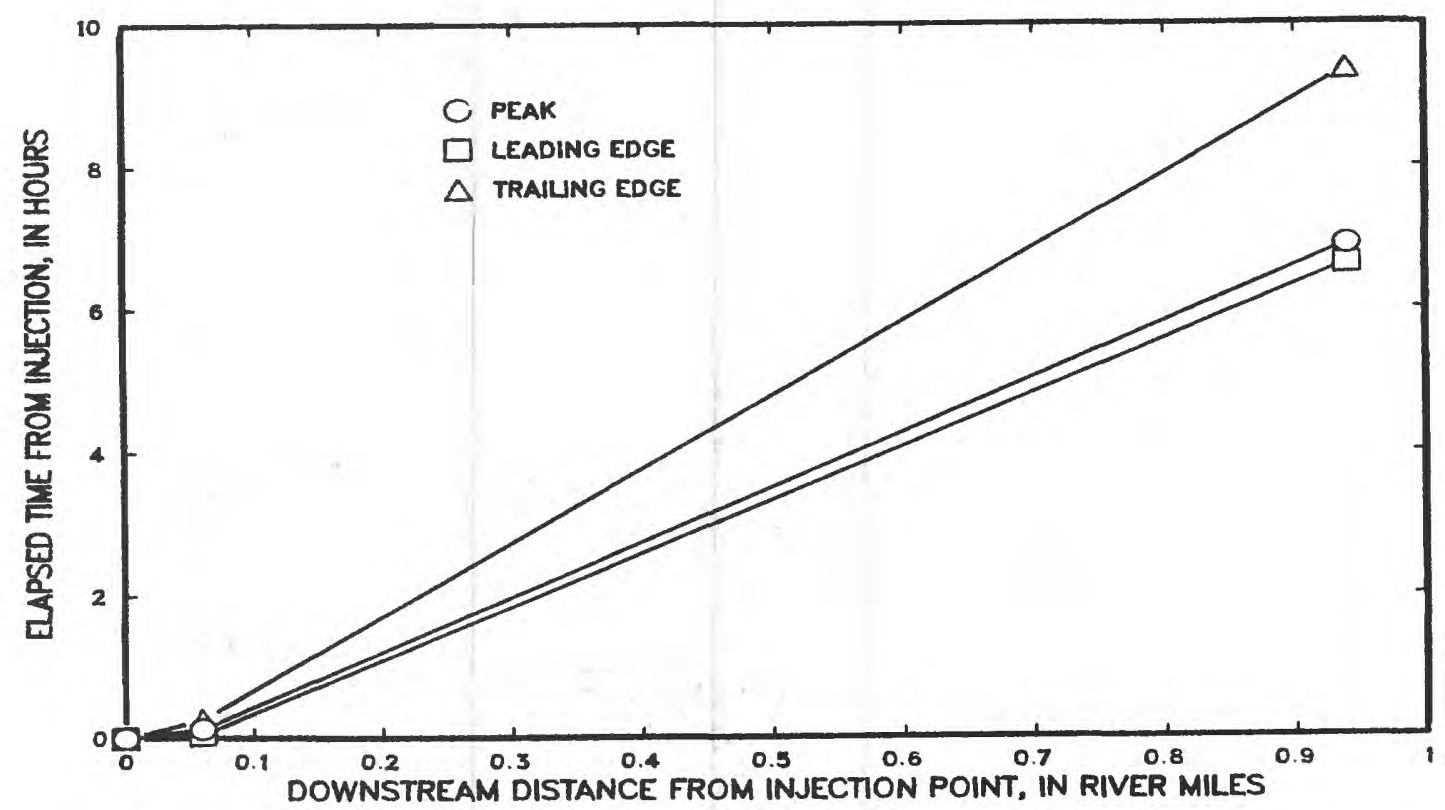

\begin{tabular}{|c|c|c|c|c|c|}
\hline $\begin{array}{l}\text { Sampling } \\
\text { point }\end{array}$ & $\begin{array}{l}\text { Downstream } \\
\text { distance } \\
\text { (miles) }\end{array}$ & $\begin{array}{l}\text { Peak dye } \\
\text { concentration } \\
\text { (micrograms } \\
\text { per liter) }\end{array}$ & $\begin{array}{l}\text { Dye area } \\
\text { (microgram- } \\
\text { hours per } \\
\text { liter) }\end{array}$ & $\begin{array}{l}\text { Time of } \\
\text { centroid } \\
\text { (hours) }\end{array}$ & $\begin{array}{l}\text { Dye cloud } \\
\text { standard } \\
\text { deviation } \\
\text { (hours) }\end{array}$ \\
\hline $\begin{array}{l}3 \\
4\end{array}$ & $\begin{array}{r}0.06 \\
.94\end{array}$ & $\begin{array}{r}99.8 \\
5.40\end{array}$ & $\begin{array}{c}15.4 \\
5.79\end{array}$ & $\begin{array}{l}0.14 \\
7.77\end{array}$ & $\begin{array}{r}0.00 \\
.73\end{array}$ \\
\hline $\begin{array}{l}\text { Sampling } \\
\text { point }\end{array}$ & $\begin{array}{l}\text { Downstream } \\
\text { distance } \\
\text { (miles) }\end{array}$ & $\begin{array}{l}\text { Peak } \\
\text { propane } \\
\text { concentration } \\
\text { (micrograms } \\
\text { per liter) }\end{array}$ & $\begin{array}{l}\text { Peak } \\
\text { ethylene } \\
\text { concentration } \\
\text { (microgram-hours } \\
\text { per liter) }\end{array}$ & $\begin{array}{l}\text { Propane } \\
\text { area } \\
\text { (microgram- } \\
\text { hours per } \\
\text { liter) }\end{array}$ & $\begin{array}{l}\text { Ethylene } \\
\text { area } \\
\text { (microgram- } \\
\text { hours per } \\
\text { liter) }\end{array}$ \\
\hline $\begin{array}{l}3 \\
4\end{array}$ & $\begin{array}{r}0.06 \\
.94\end{array}$ & $\begin{array}{r}640.0 \\
6.80\end{array}$ & $\begin{array}{r}1,300.0 \\
4.20\end{array}$ & $\begin{array}{r}103.0 \\
6.52\end{array}$ & $\begin{array}{r}190.0 \\
3.95\end{array}$ \\
\hline
\end{tabular}

Figure 12.--Traveltime-distance curves, dye concentration data, and hydrocarbon gas data for subreach B of McGirts Creek-Ortega River at Jacksonville. 

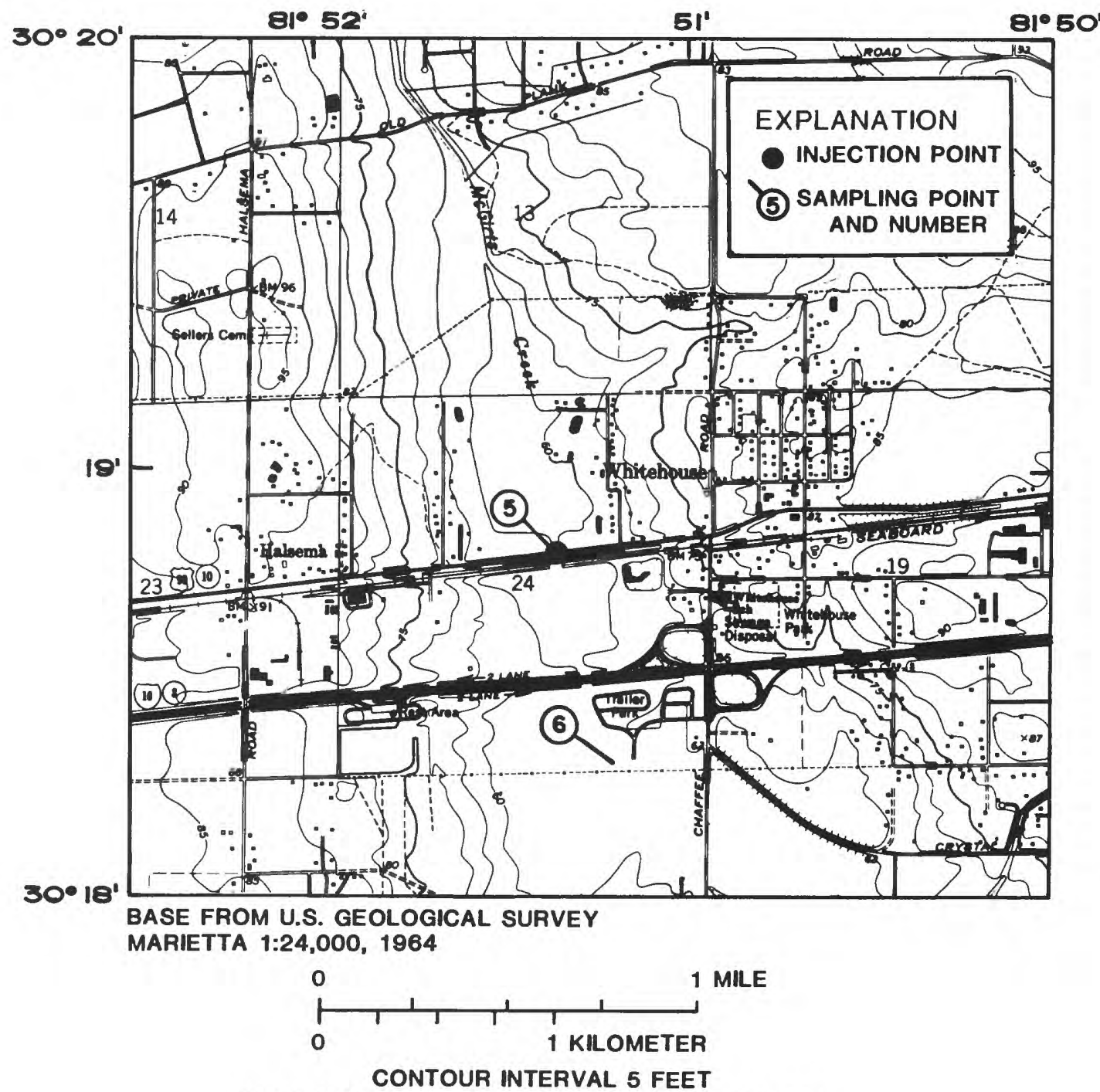

NATIONAL GEODETIC VERTICAL DATUM OF 1929

\begin{tabular}{lcccccccc}
\hline Subreach & Date & $\begin{array}{c}\text { Length } \\
\text { (feet) }\end{array}$ & $\begin{array}{c}\text { Mean } \\
\text { width } \\
\text { (feet) }\end{array}$ & $\begin{array}{c}\text { Mean cross- } \\
\text { sectional } \\
\text { area (square } \\
\text { feet) }\end{array}$ & $\begin{array}{c}\text { Mean } \\
\text { slope } \\
\text { (foot per } \\
\text { foot) }\end{array}$ & $\begin{array}{c}\text { Upstream } \\
\text { discharge } \\
\text { (cubic feet } \\
\text { per second) }\end{array}$ & $\begin{array}{c}\text { Downstream } \\
\text { discharge } \\
\text { (cubic feet } \\
\text { per second) }\end{array}$ & $\begin{array}{c}\text { Time } \\
\text { of } \\
\text { (hovel } \\
\text { (hours) }\end{array}$ \\
\hline C - 5 to 6 & $11 / 02 / 82$ & 2,800 & 18.0 & 22.47 & 0.00562 & 3.00 & 3.11 & 5.68 \\
\hline
\end{tabular}

Figure 13.--Location of and hydraulic data for subreach C of McGirts CreekOrtega River at Jacksonville. 

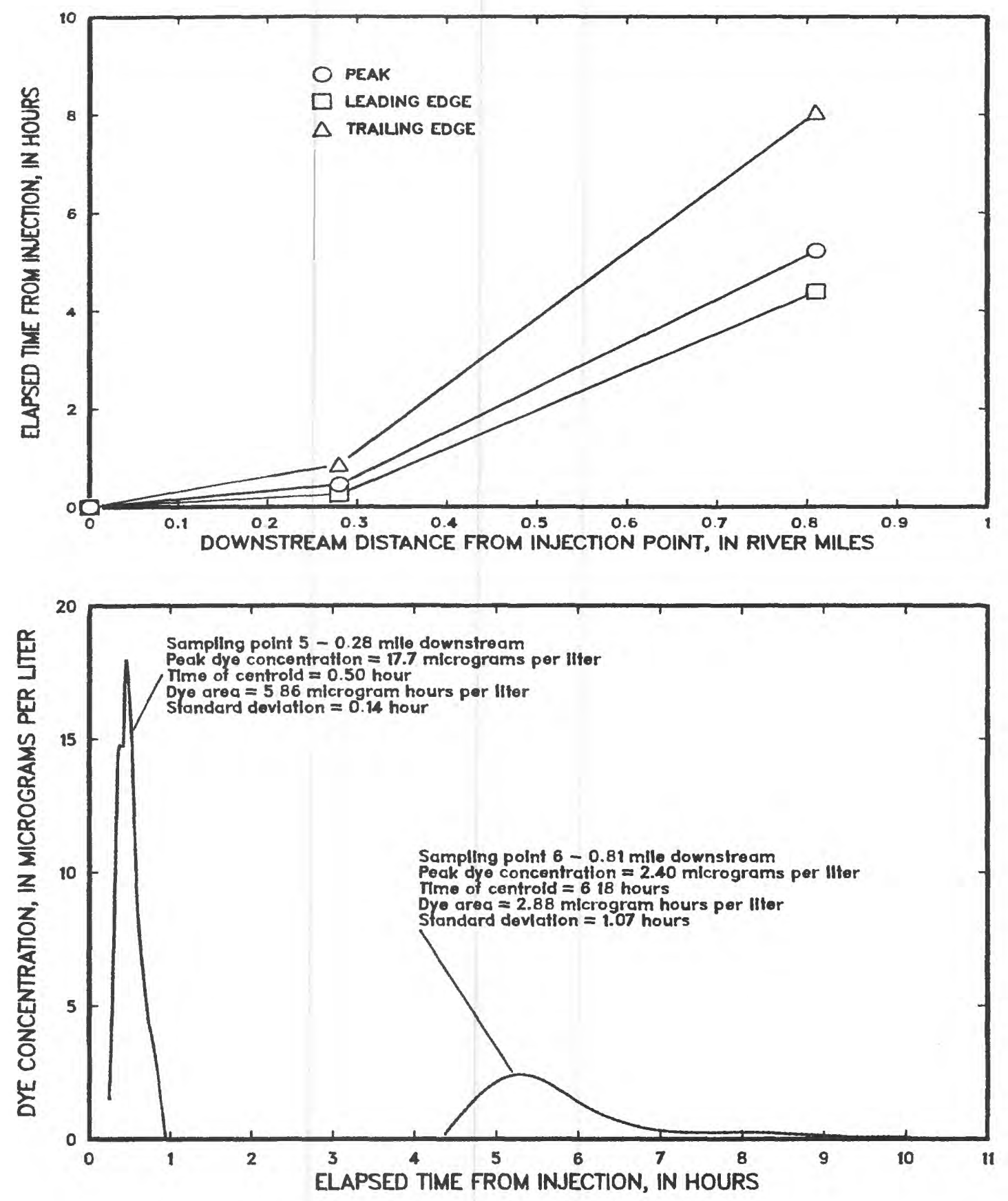

Figure 14.--Traveltime-distance and dye concentration-time curves for subreach C of McGirts Creek-Ortega River at Jacksonville. 
Subreach D (fig. 15) is at first well defined then diverges into several small tributaries as it flows through a swamp. The stream reforms above Normandy Boulevard and is pooled. From Normandy Boulevard to 103 rd Street, channel conditions alternate between pooled and tranquil flow with depths genera11y less than 1.0 foot. Subreach D was measured on February 24,1985 , and the water temperature was $13.5{ }^{\circ} \mathrm{C}$. Figure 16 presents hydrocarbon gas data and illustrates the time of travel for the leading edge, peak, and trailing edge of the dye concentrations.

Subreaches $E$ and $F$ (fig. 17) were fairly uniform in width with some pooling and riffles due to debris jams in the channel. Small meanders are numerous compared with the area below OLF Whitehouse. The streambed was a loosely packed sand and water color was dark. Channel slope had decreased to the point that flow was considered sluggish. Subreaches $E$ and F were measured on October 4, 1982, and water temperature was $22.5{ }^{\circ} \mathrm{C}$. Time of trave 1 and time series data for these subreaches are given in figure 18. Time series data for ethylene and propane are shown in figure 19.

Reaeration coefficients for the subreaches of McGirts Creek-Ortega River are given below. Significant differences were found between the ethylene and propane values for subreaches B, C, E, and F. The final $K_{r}$ values for these subreaches are the lower, more conservative propane values. All of these subreaches with the exception of B were known to be receiving wastewater treatment facility effluent during the study.

\begin{tabular}{|c|c|c|c|c|}
\hline Subreach & $\begin{array}{l}\text { Sampling } \\
\text { points }\end{array}$ & $\begin{array}{c}\mathrm{K}_{\mathrm{p}} \\
\left(\text { days }^{-1}\right)\end{array}$ & $\begin{array}{c}\mathrm{K}_{\mathrm{e}} \\
\left(\text { days }^{-1}\right)\end{array}$ & $\begin{array}{c}\mathrm{K}_{r} \\
\left(\text { days }^{-1}\right)\end{array}$ \\
\hline A & 1 to 2 & $5.40 \pm 1.98$ & $4.72 \pm 0.20$ & $4.73 \pm 0.20$ \\
\hline B & 3 to 4 & $10.6 \pm .4$ & $14.3 \pm$ & $10.6 \pm$ \\
\hline $\mathrm{C}$ & 5 to 6 & $13.8 \pm .6$ & $18.9 \pm 1.1$ & $13.8 \pm$ \\
\hline D & 7 to 8 & $4.19 \pm 1.14$ & $4.42 \pm$ & $4.32 \pm$ \\
\hline $\mathrm{E}$ & 9 to 10 & $4.52 \pm .36$ & $10.2 \pm .5$ & $4.52 \pm$ \\
\hline F & 10 to 11 & $6.45 \pm .62$ & $20.3 \pm 6.2$ & $6.45 \pm$ \\
\hline
\end{tabular}



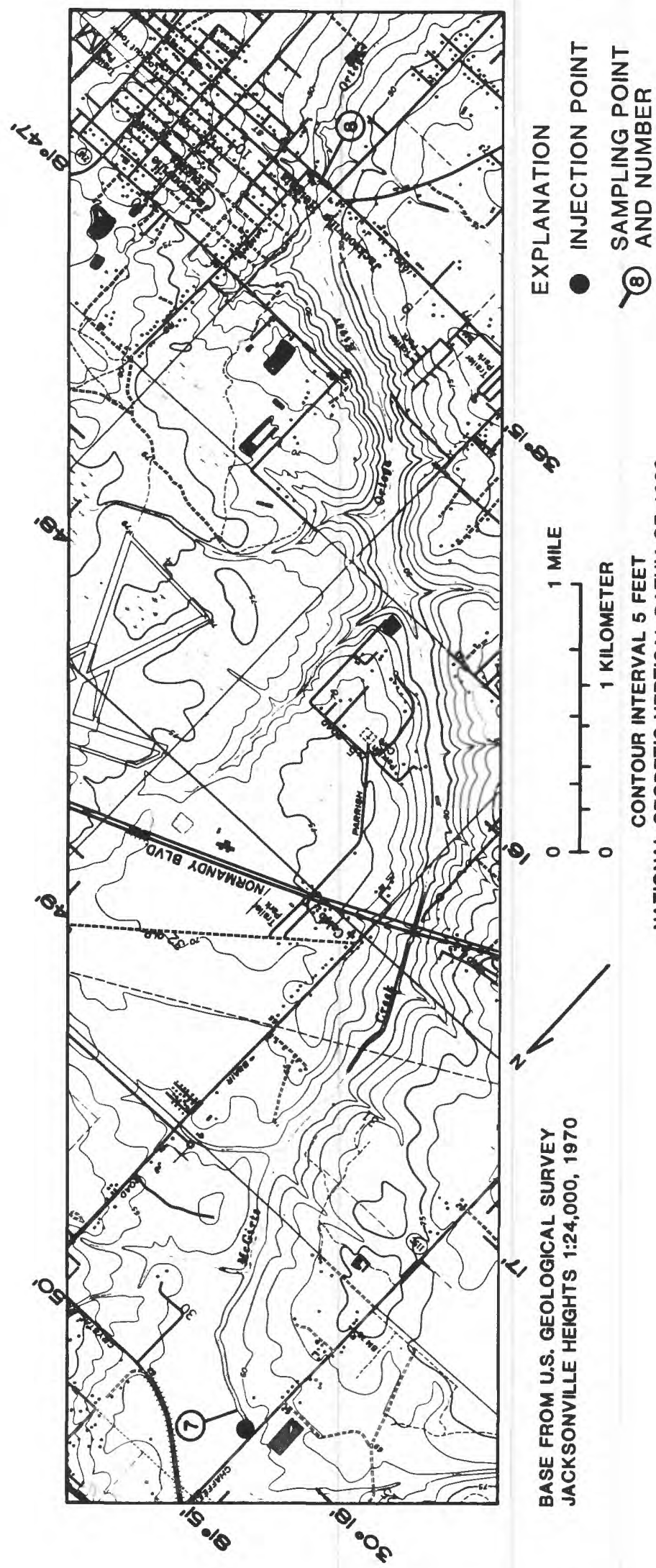

क
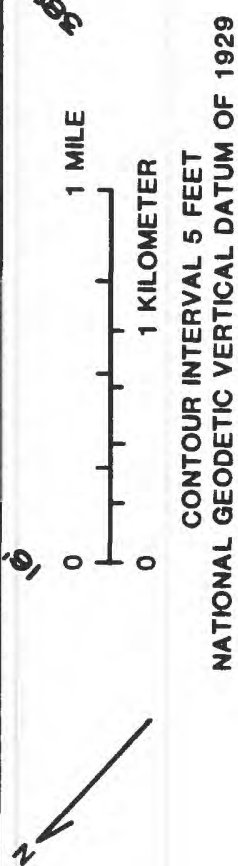

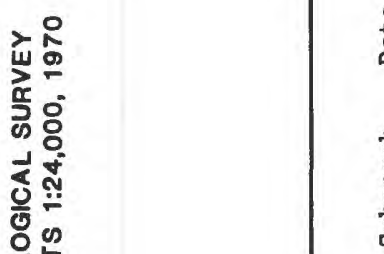

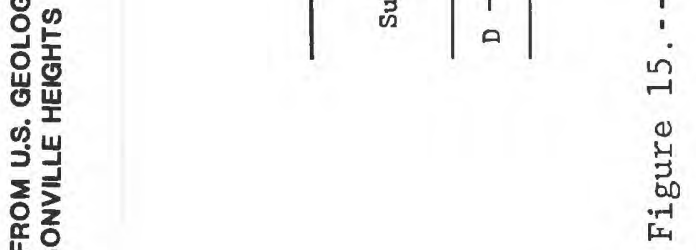




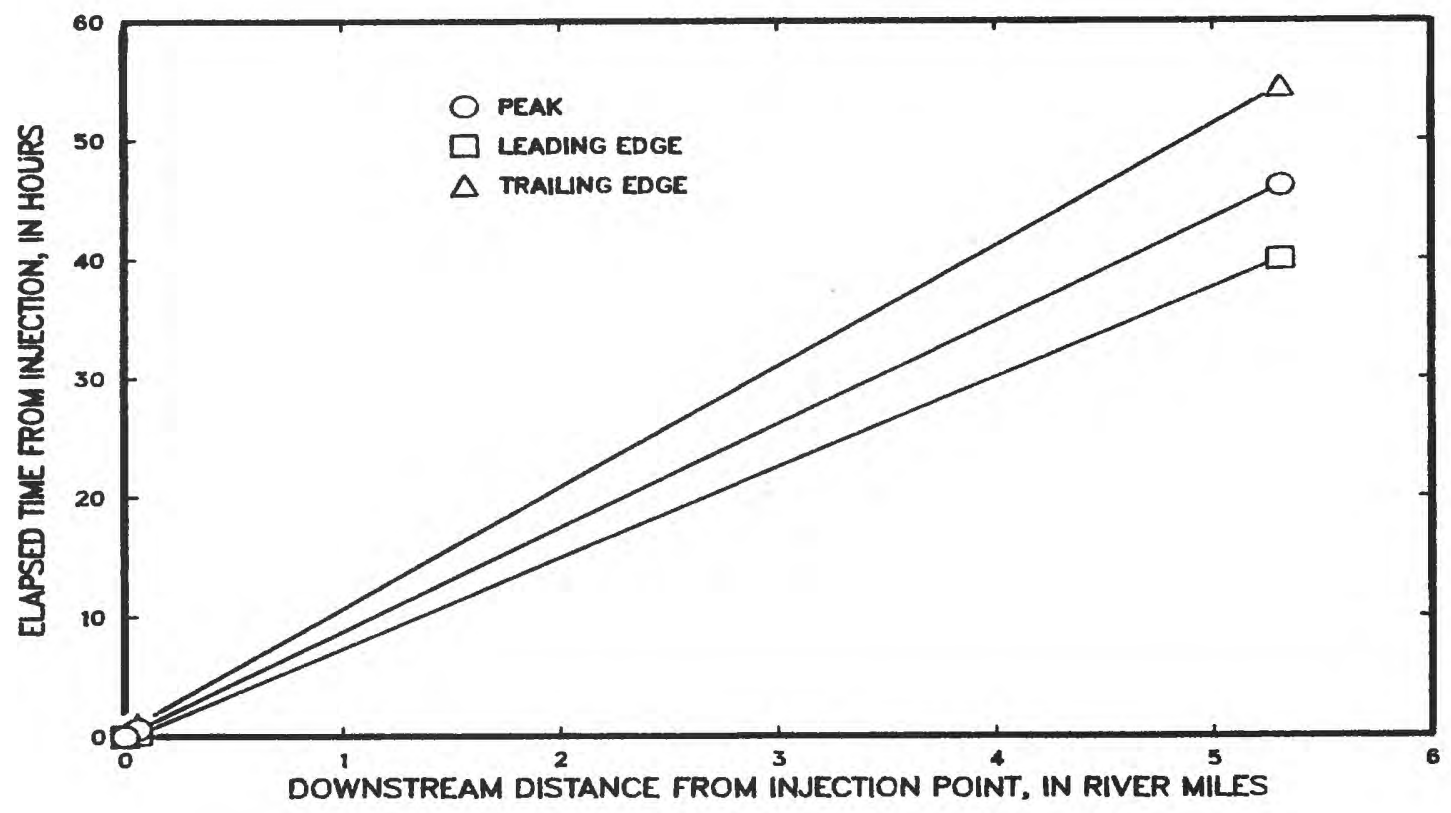

\begin{tabular}{|c|c|c|c|c|c|}
\hline $\begin{array}{l}\text { Sampling } \\
\text { point }\end{array}$ & $\begin{array}{l}\text { Downstream } \\
\text { distance } \\
\text { (miles) }\end{array}$ & $\begin{array}{l}\text { Peak dye } \\
\text { concentration } \\
\text { (micrograms } \\
\text { per liter) }\end{array}$ & $\begin{array}{l}\text { Dye area } \\
\text { (microgram- } \\
\text { hours per } \\
\text { liter) }\end{array}$ & $\begin{array}{l}\text { Time of } \\
\text { centroid } \\
\text { (hours) }\end{array}$ & $\begin{array}{l}\text { Dye cloud } \\
\text { standard } \\
\text { deviation } \\
\text { (hours) }\end{array}$ \\
\hline $\begin{array}{l}7 \\
8\end{array}$ & $\begin{array}{l}0.06 \\
5.31\end{array}$ & $\begin{array}{r}91.6 \\
.70\end{array}$ & $\begin{array}{c}52.9 \\
6.68\end{array}$ & $\begin{array}{l}0.59 \\
47.8\end{array}$ & $\begin{array}{l}0.22 \\
3.27\end{array}$ \\
\hline $\begin{array}{l}\text { Sampling } \\
\text { point }\end{array}$ & $\begin{array}{l}\text { Downstream } \\
\text { distance } \\
\text { (miles) }\end{array}$ & $\begin{array}{l}\text { Peak } \\
\text { propane } \\
\text { concentration } \\
\text { (micrograms } \\
\text { per liter) }\end{array}$ & $\begin{array}{l}\text { Peak } \\
\text { ethylene } \\
\text { concentration } \\
\text { (microgram-hours } \\
\text { per liter) }\end{array}$ & $\begin{array}{l}\text { Propane } \\
\text { area } \\
\text { (microgram- } \\
\text { hours per } \\
\text { liter) }\end{array}$ & $\begin{array}{l}\text { Ethylene } \\
\text { area } \\
\text { (microgram- } \\
\text { hours per } \\
\text { liter) }\end{array}$ \\
\hline $\begin{array}{l}7 \\
8\end{array}$ & $\begin{array}{l}0.06 \\
5.31\end{array}$ & $\begin{array}{r}190.0 \\
.10\end{array}$ & $\begin{array}{r}390.0 \\
.05\end{array}$ & $\begin{array}{r}122.0 \\
.10\end{array}$ & $\begin{array}{r}235.0 \\
.13\end{array}$ \\
\hline
\end{tabular}

Figure 16.--Traveltime-distance curves, dye concentration data, and hydrocarbon gas concentration data for subreach D of McGirts Creek-Ortega River at Jacksonville. 


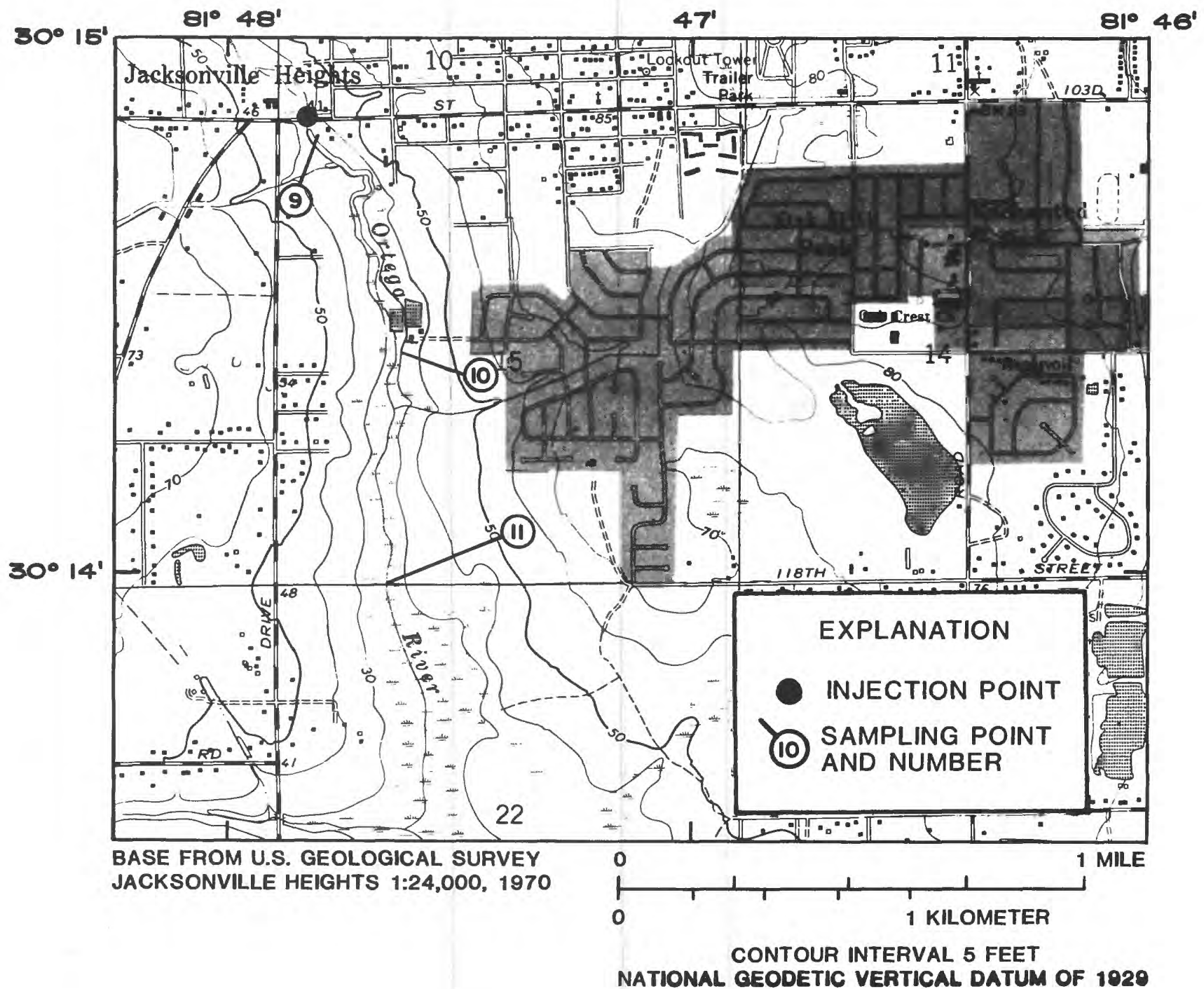

\begin{tabular}{|c|c|c|c|c|c|c|c|c|}
\hline Subreach & Date & $\begin{array}{l}\text { Length } \\
\text { (feet) }\end{array}$ & $\begin{array}{l}\text { Mean } \\
\text { width } \\
\text { (feet) }\end{array}$ & $\begin{array}{l}\text { Mean cross- } \\
\text { sectional } \\
\text { area (square } \\
\text { feet) }\end{array}$ & $\begin{array}{l}\text { Mean } \\
\text { slope } \\
\text { (foot per } \\
\text { foot) }\end{array}$ & $\begin{array}{l}\text { Upstream } \\
\text { discharge } \\
\text { (cubic feet } \\
\text { per second) }\end{array}$ & $\begin{array}{l}\text { Downstream } \\
\text { discharge } \\
\text { (cubic feet } \\
\text { per sacond) }\end{array}$ & $\begin{array}{l}\text { Time } \\
\text { of } \\
\text { trave1 } \\
\text { (hours) }\end{array}$ \\
\hline $\begin{array}{l}E-9 \text { to } 10 \\
F-10 \text { to } 11\end{array}$ & $\begin{array}{l}10 / 04 / 82 \\
10 / 04 / 82\end{array}$ & $\begin{array}{l}3,220 \\
2,910\end{array}$ & $\begin{array}{l}12.6 \\
14.7\end{array}$ & $\begin{array}{l}60.59 \\
54.3\end{array}$ & $\begin{array}{r}0.000534 \\
.000535\end{array}$ & $\begin{array}{l}8.20 \\
9.60\end{array}$ & $\begin{array}{c}9.60 \\
10.1\end{array}$ & $\begin{array}{l}6.06 \\
4.42\end{array}$ \\
\hline
\end{tabular}

Figure 17.--Location of and hydraulic data for subreaches $\mathrm{E}$ and $\mathrm{F}$ of McGirts CreekOrtega River at Jacksonville. 

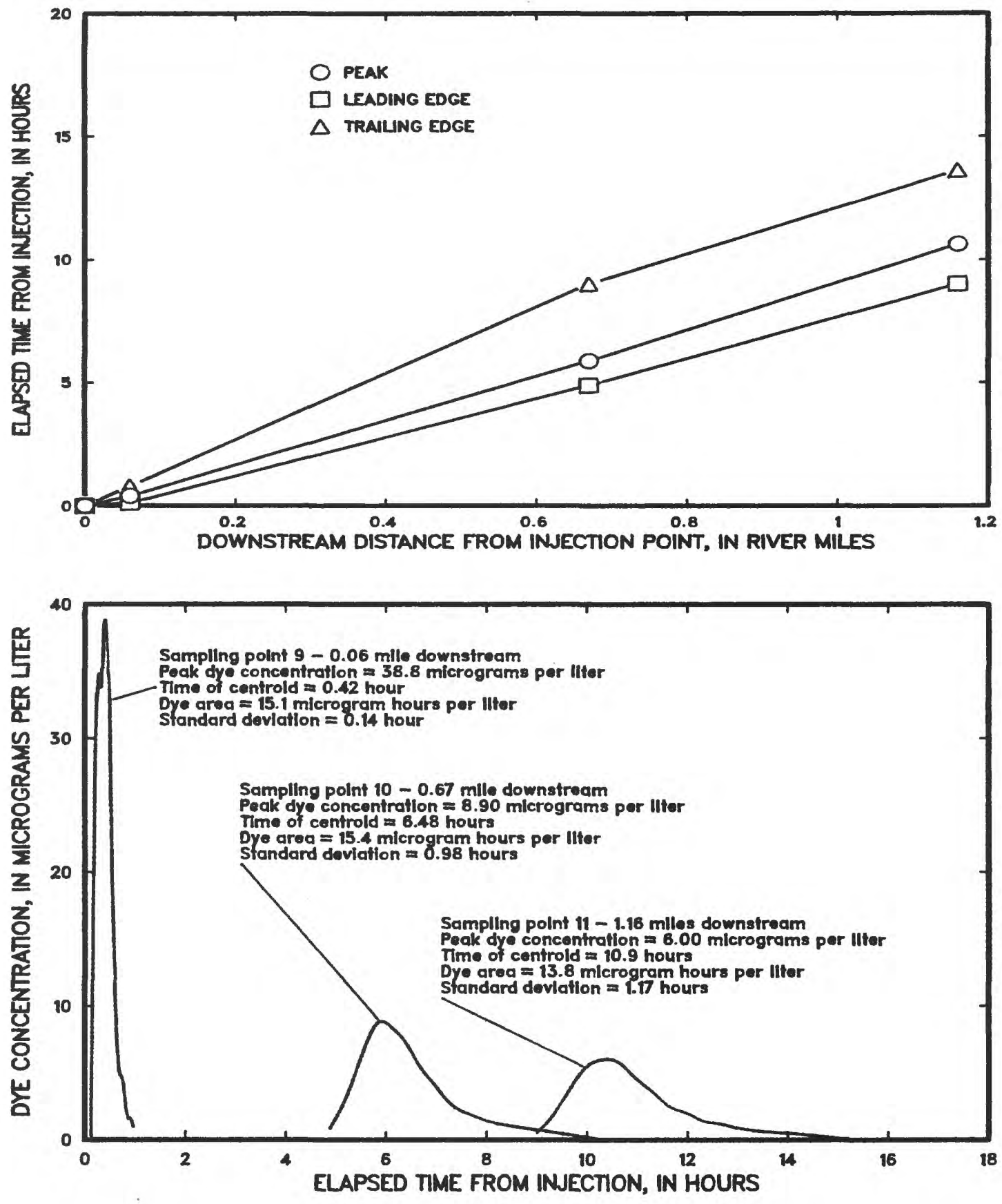

Figure 18.--Traveltime-distance and dye concentration-time curves for subreaches $\mathrm{E}$ and $\mathrm{F}$ of McGirts Creek-Ortega River at Jacksonville. 


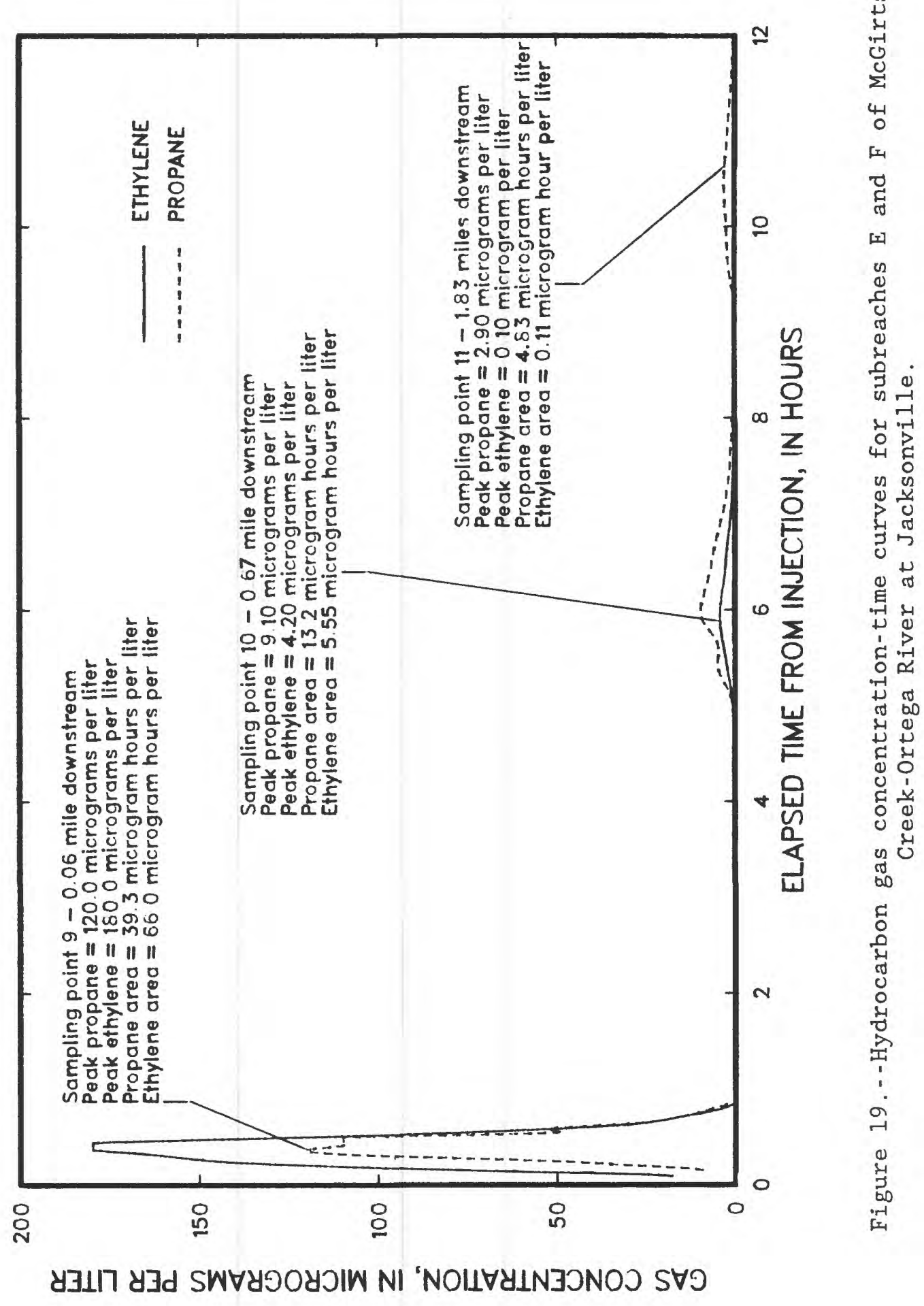


Country Club Creek (fig. 20) is located north of Normandy Boulevard in Jacksonville. The study reach extends from Hammond Road to the 8300 block of Country Club Boulevard. Stream conditions are generally uniform throughout the study reach with slightly shallower depths upstream. The bottom is a firm sand and water color is clear. Two studies were performed at this stream. The first was performed on June 29, 1983, and considered the entire stream segment as one subreach designated as $A$ in figure 20 . The water temperature during this measurement was $24.5{ }^{\circ} \mathrm{C}$. The second measurement was performed on December 7, 1983, and divided the stream segment into two subreaches designated $B$ and $C$ on figure 20 . Water temperature during this second measurement was $17.5{ }^{\circ} \mathrm{C}$. During the second study ethylene was not used as a tracer gas. The nearest long-term station for which low-flow frequencies were available was the Ortega River at Jacksonville. Discharge for the Ortega River at Jacksonville during the first study was $33 \mathrm{ft}^{3} / \mathrm{s}$ and was not available for the second study. The $7 Q, 10$ for the ortega River is computed to be $0.47 \mathrm{ft}^{3} / \mathrm{s}$.

Figures 21 and 23 illustrate the times of travel of the leading edge, peak, and trailing edge of the dye cloud from the point of injection to the downstream sample points. Figures $21,22,23$, and 24 show time series data of dye, propane, and ethylene concentrations at sampling points 1,2 , and 3 . Reaeration coefficients computed from these data are given below. No significant differences between the propane and ethylene coefficients were found during the first measurement. Ethylene was not used during the second measurement as stated previously.

\begin{tabular}{cccccc}
\hline Subreach & $\begin{array}{c}\text { Sampling } \\
\text { points }\end{array}$ & $\begin{array}{c}\mathrm{K}_{\mathrm{p}} \\
\text { (days }^{-1} \text { ) }\end{array}$ & $\begin{array}{c}\mathrm{K}_{\mathrm{e}} \\
\text { (days }^{-1} \text { ) }\end{array}$ & $\begin{array}{c}\mathrm{K}_{\mathrm{r}} \\
\text { (days }^{-1} \text { ) }\end{array}$ \\
\hline & 1 to 3 & $18.1 \pm 1.3$ & $23.7 \pm 2.4$ & $19.5 \pm 1.3$ \\
$\mathrm{~A}$ & 1 to 2 & $14.6 \pm 1.6$ & -- & $14.6 \pm 1.6$ \\
$\mathrm{~B}$ & 2 to 3 & $14.7 \pm 1.5$ & -- & $14.7 \pm 1.5$
\end{tabular}




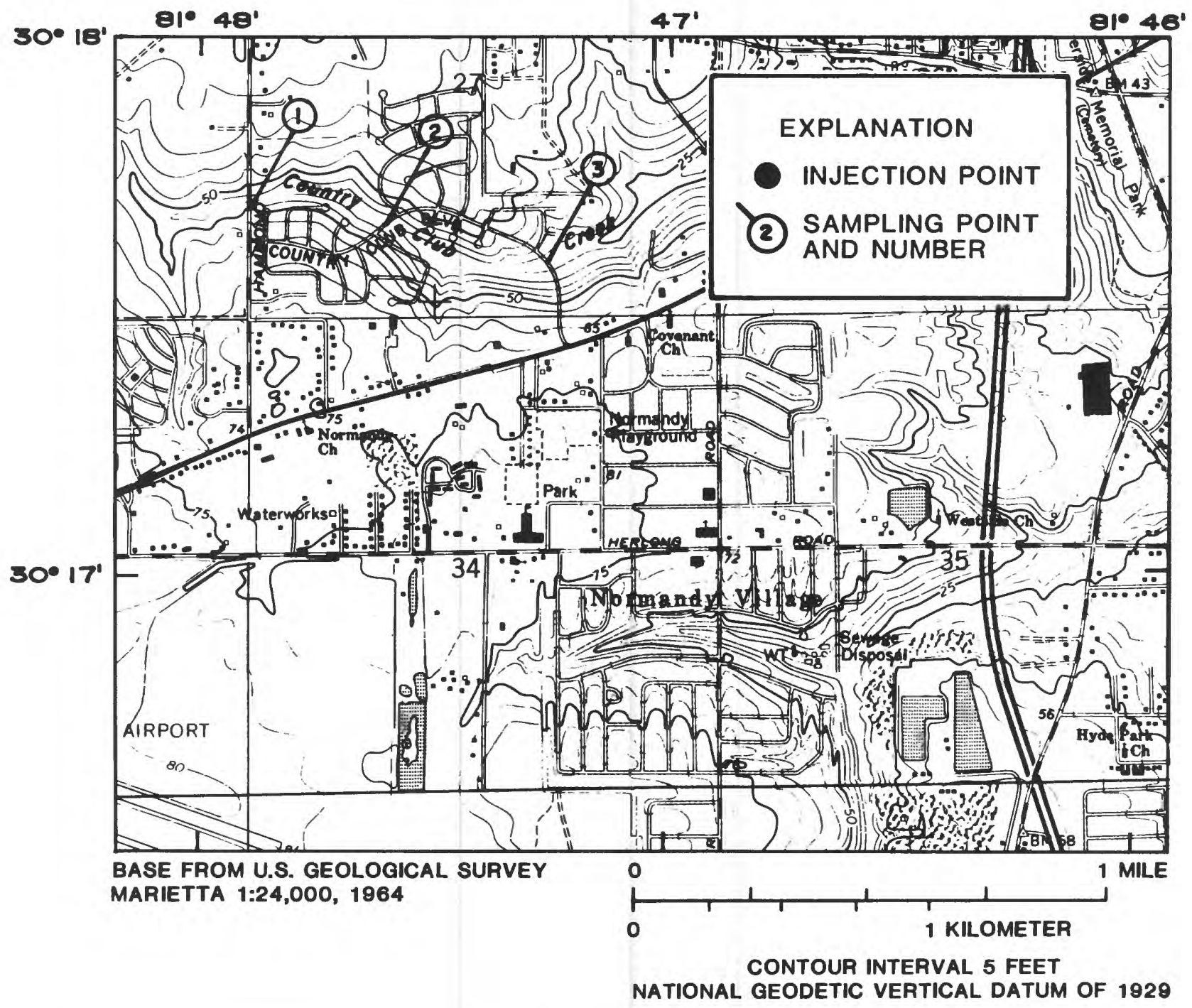

\begin{tabular}{|c|c|c|c|c|c|c|c|c|}
\hline Subreach & Date & $\begin{array}{l}\text { Length } \\
\text { (feet) }\end{array}$ & $\begin{array}{l}\text { Mean } \\
\text { width } \\
\text { (feet) }\end{array}$ & $\begin{array}{l}\text { Mean cross- } \\
\text { sectional } \\
\text { area (square } \\
\text { feet) }\end{array}$ & $\begin{array}{l}\text { Mean } \\
\text { slope } \\
\text { (foot per } \\
\text { foot) }\end{array}$ & $\begin{array}{l}\text { Upstream } \\
\text { discharge } \\
\text { (cubic feet } \\
\text { per second) }\end{array}$ & $\begin{array}{l}\text { Downstream } \\
\text { discharge } \\
\text { (cubic feet } \\
\text { per second) }\end{array}$ & $\begin{array}{l}\text { Time } \\
\text { of } \\
\text { trave1 } \\
\text { (hours) }\end{array}$ \\
\hline $\begin{array}{l}A-1 \text { to } 3 \\
B-1 \text { to } 2 \\
C-2 \text { to } 3\end{array}$ & $\begin{array}{l}06 / 29 / 83 \\
12 / 07 / 83 \\
12 / 07 / 83\end{array}$ & $\begin{array}{l}3,640 \\
1,690 \\
1,950\end{array}$ & $\begin{array}{l}9.10 \\
9.00 \\
9.20\end{array}$ & $\begin{array}{l}9.92 \\
7.80 \\
10.0\end{array}$ & $\begin{array}{r}0.00295 \\
.00387 \\
.00215\end{array}$ & $\begin{array}{l}2.69 \\
2.05 \\
2.02\end{array}$ & $\begin{array}{l}2.80 \\
2.02 \\
2.52\end{array}$ & $\begin{array}{l}3.65 \\
1.80 \\
2.40\end{array}$ \\
\hline
\end{tabular}

Figure 20.--Location of and hydraulic data for Country Club Creek at Jacksonville. 

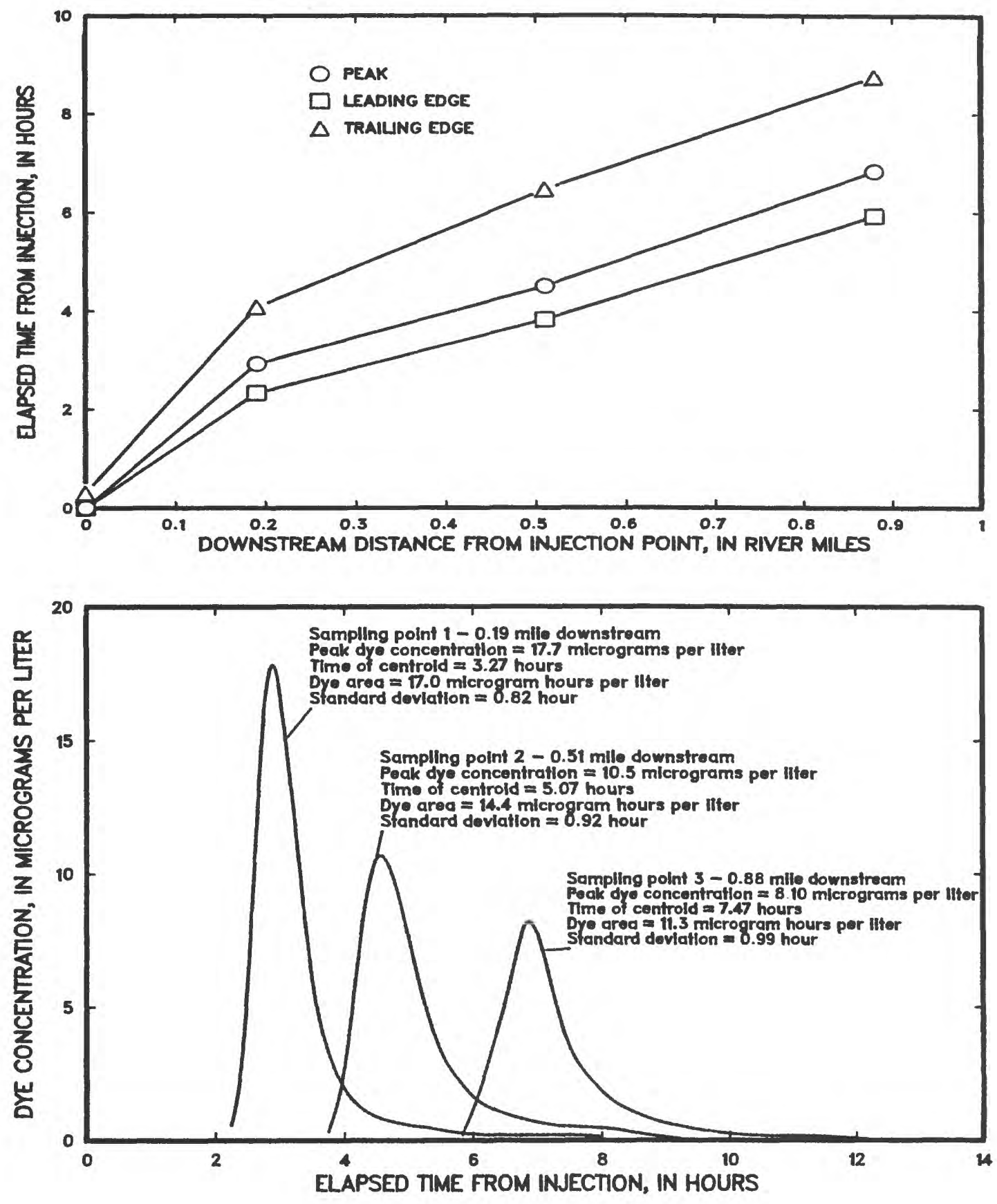

Figure 21.--Traveltime-distance and dye concentration-time curves for subreach A of Country Club Creek at Jacksonville. 


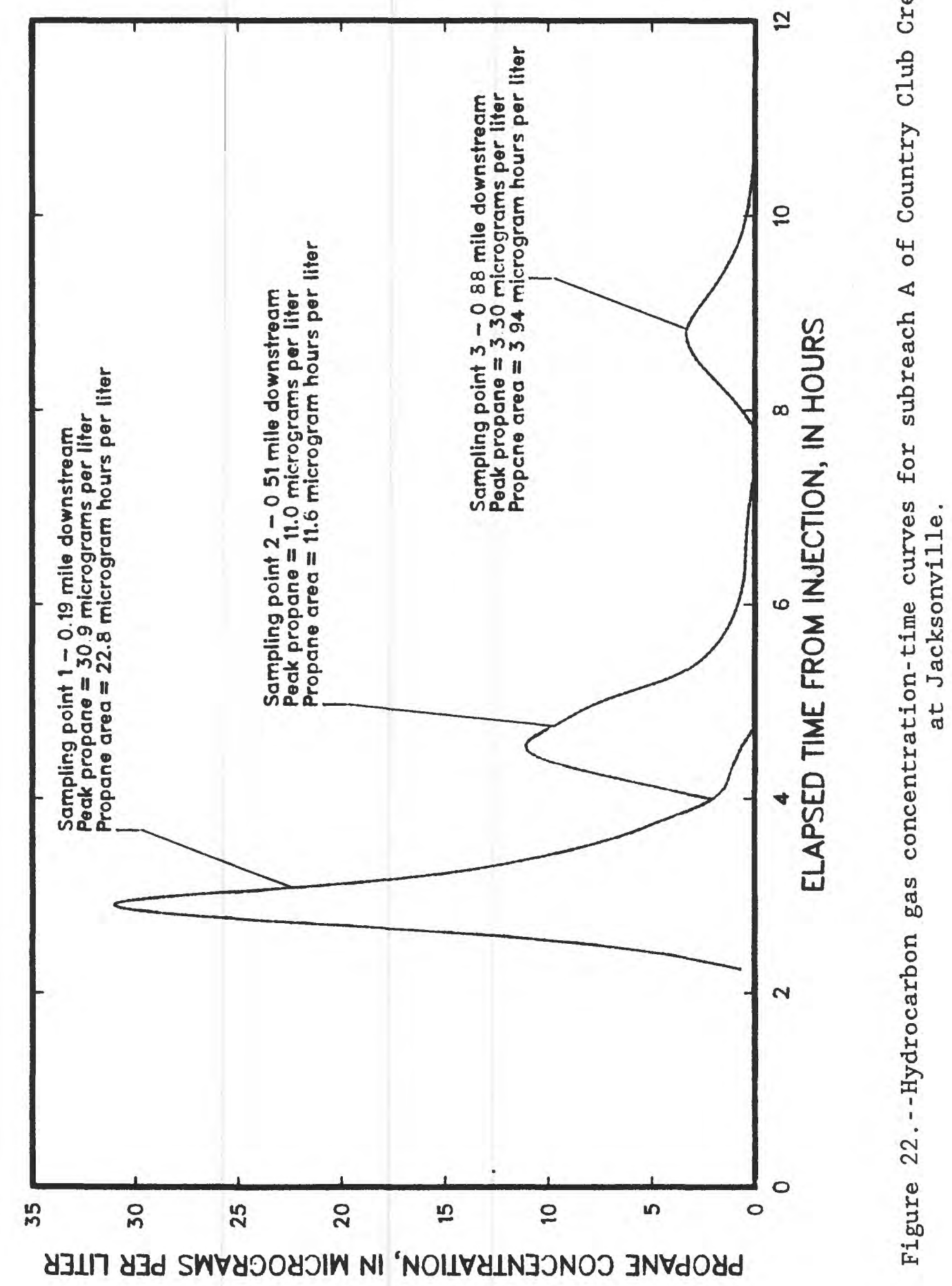



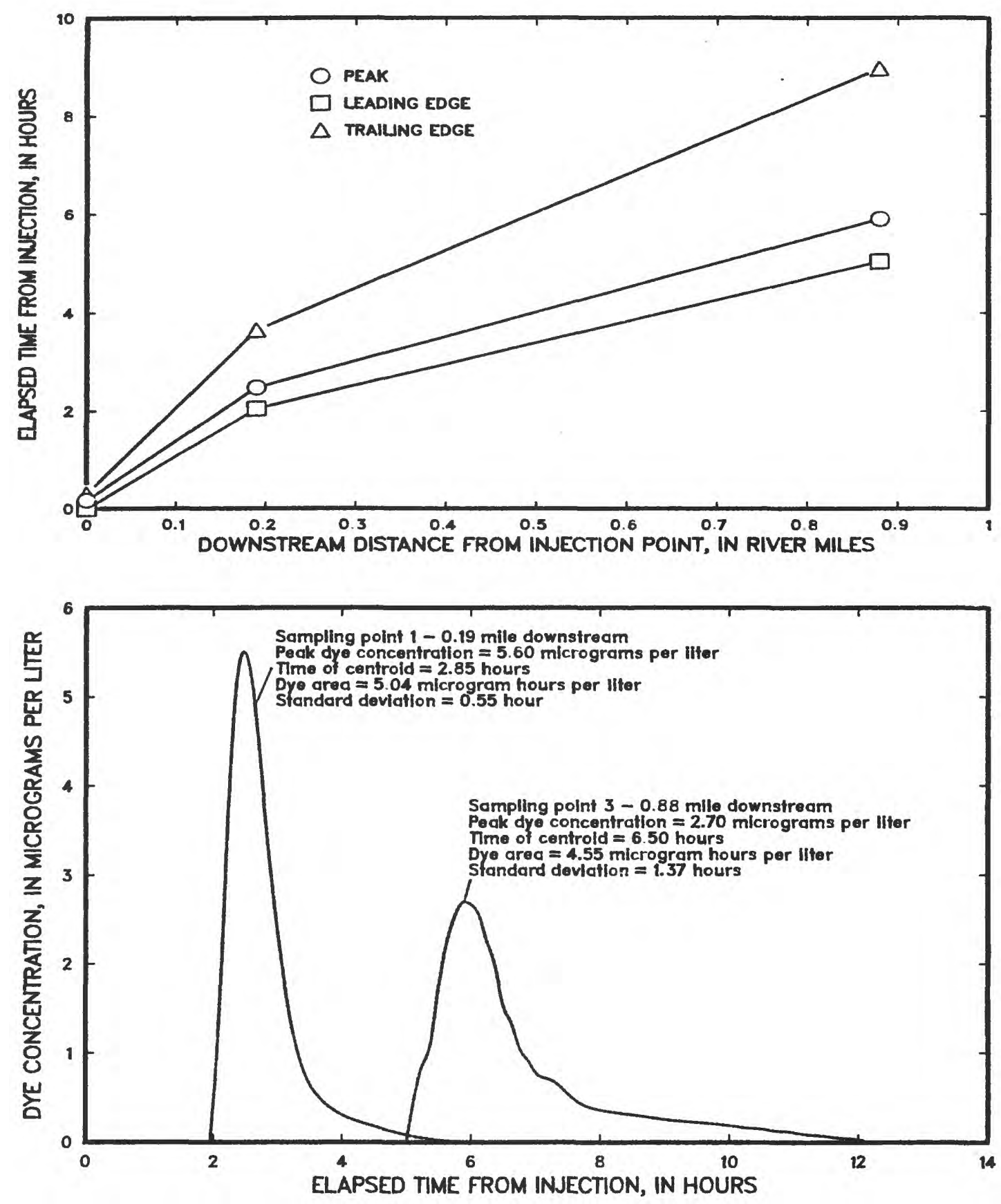

Figure 23.--Traveltime-distance and dye concentration-time curves for subreaches B and C of Country Club Creek at Jacksonville. 


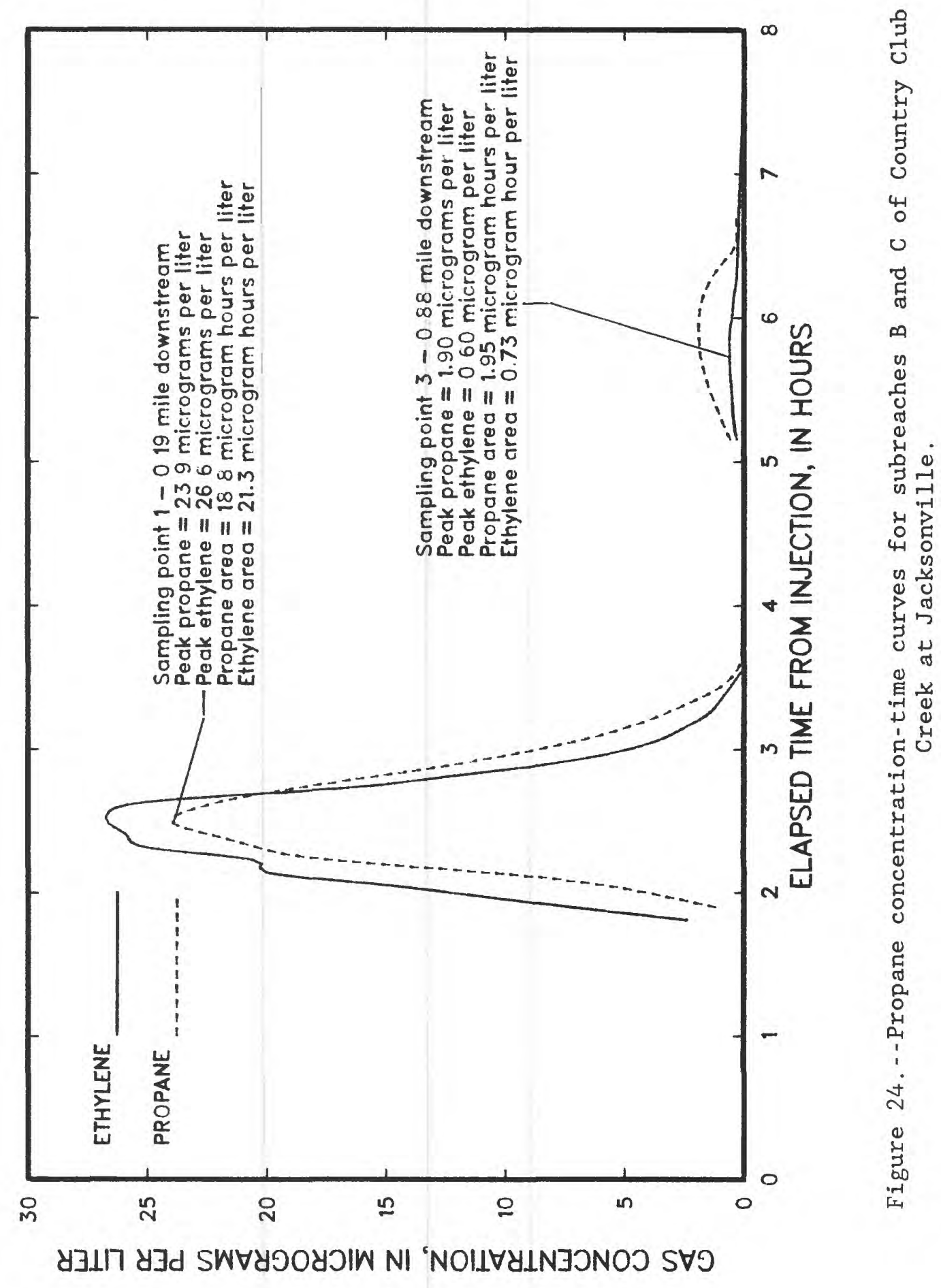




\section{Unnamed Tributary to Wills Branch at Jacksonville}

This unnamed tributary (fig. 25) to Wills Branch is located south of Herlong Road in Normandy Village. The study reach extends from Fouraker Road to Herlong Road. The upstream channel is narrow with shallow depths and high velocities. The downstream channel is wider and deeper with slower velocities. The streambed is generally sandy throughout and water color is clear. The study was performed over two subreaches, A and B, on December 8, 1983 , and the water temperature during the study was $13.5^{\circ} \mathrm{C}$. Discharge for the Ortega River at Jacksonville on the day this tributary was studied is not available, so no low-flow comparison can be made.

Figure 26 illustrates the times of travel of the leading edge, peak, and trailing edge of the dye cloud from the injection point to the downstream sample points. Figures 26 and 27 show time series data of dye and propane concentrations at the downstream sample points. Reaeration coefficients computed from these data are given below.

\begin{tabular}{clccc}
\hline Subreach & $\begin{array}{l}\text { Sampling } \\
\text { points }\end{array}$ & $\begin{array}{c}\mathrm{K}_{\mathrm{p}} \\
\text { (days }^{-1} \text { ) }\end{array}$ & $\begin{array}{c}\mathrm{K}_{\mathrm{r}} \\
\text { (days }^{-1} \text { ) }\end{array}$ \\
\hline A & 1 to 2 & $45.9 \pm 6.2$ & $45.9 \pm 6.2$ \\
B & 2 to 3 & $12.6 \pm 4.5$ & $12.6 \pm 4.5$
\end{tabular}




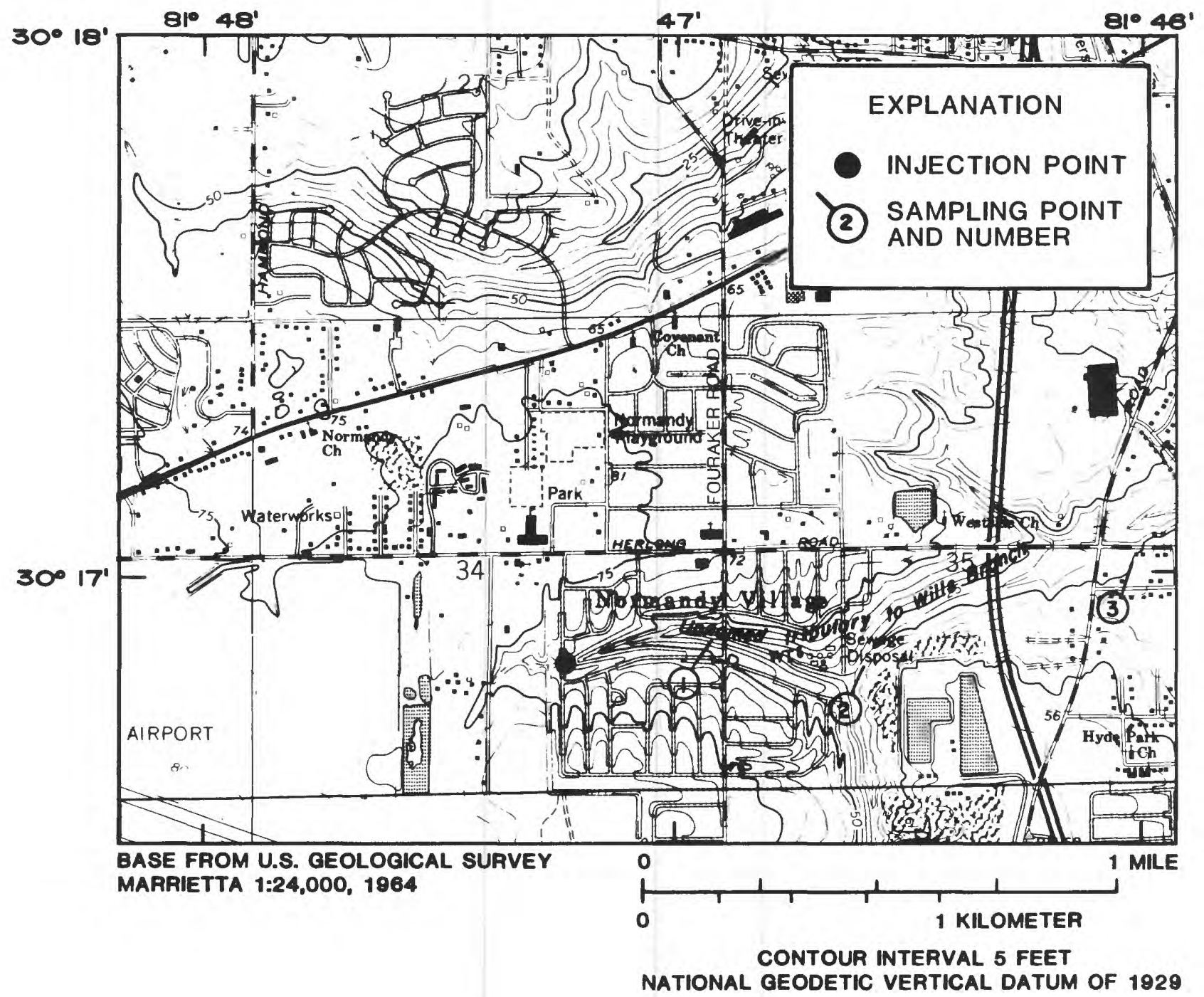

\begin{tabular}{|c|c|c|c|c|c|c|c|c|}
\hline Subreach & Date & $\begin{array}{l}\text { Length } \\
\text { (feet) }\end{array}$ & $\begin{array}{l}\text { Mean } \\
\text { width } \\
\text { (feet) }\end{array}$ & $\begin{array}{l}\text { Mean cross- } \\
\text { sectional } \\
\text { area (square } \\
\text { feet) }\end{array}$ & $\begin{array}{l}\text { Mean } \\
\text { slope } \\
\text { (foot per } \\
\text { foot) }\end{array}$ & $\begin{array}{l}\text { Upstream } \\
\text { discharge } \\
\text { (cubic feet } \\
\text { per second) }\end{array}$ & $\begin{array}{l}\text { Downstream } \\
\text { discharge } \\
\text { (cubic feet } \\
\text { per second) }\end{array}$ & $\begin{array}{l}\text { Time } \\
\text { of } \\
\text { travel } \\
\text { (hours) }\end{array}$ \\
\hline $\begin{array}{l}A-1 \text { to } 2 \\
B-2 \text { to } 3\end{array}$ & $\begin{array}{l}12 / 08 / 83 \\
12 / 08 / 83\end{array}$ & $\begin{array}{l}1,320 \\
3,060\end{array}$ & $\begin{array}{l}3.95 \\
7.40\end{array}$ & $\begin{array}{l}1.38 \\
3.98\end{array}$ & $\begin{array}{r}0.00684 \\
.00308\end{array}$ & $\begin{array}{r}0.28 \\
.43\end{array}$ & $\begin{array}{l}0.43 \\
1.41\end{array}$ & $\begin{array}{l}1.45 \\
3.68\end{array}$ \\
\hline
\end{tabular}

Figure 25.--Location of and hydraulic data for the unnamed tributary to Wills Branch at Jacksonville. 

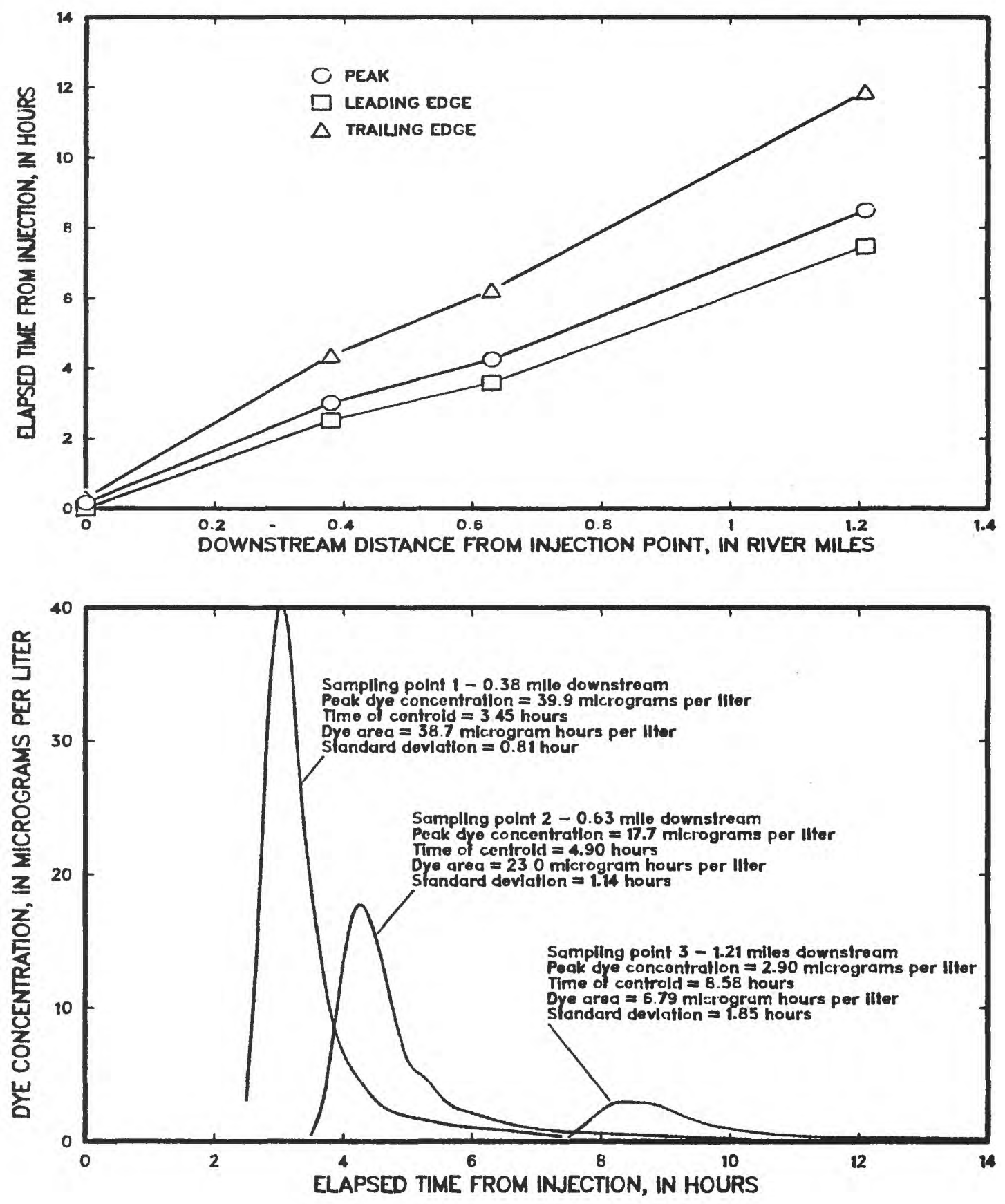

Figure 26.--Traveltime-distance and dye concentration-time curves for the unnamed tributary to Wills Branch at Jacksonville. 


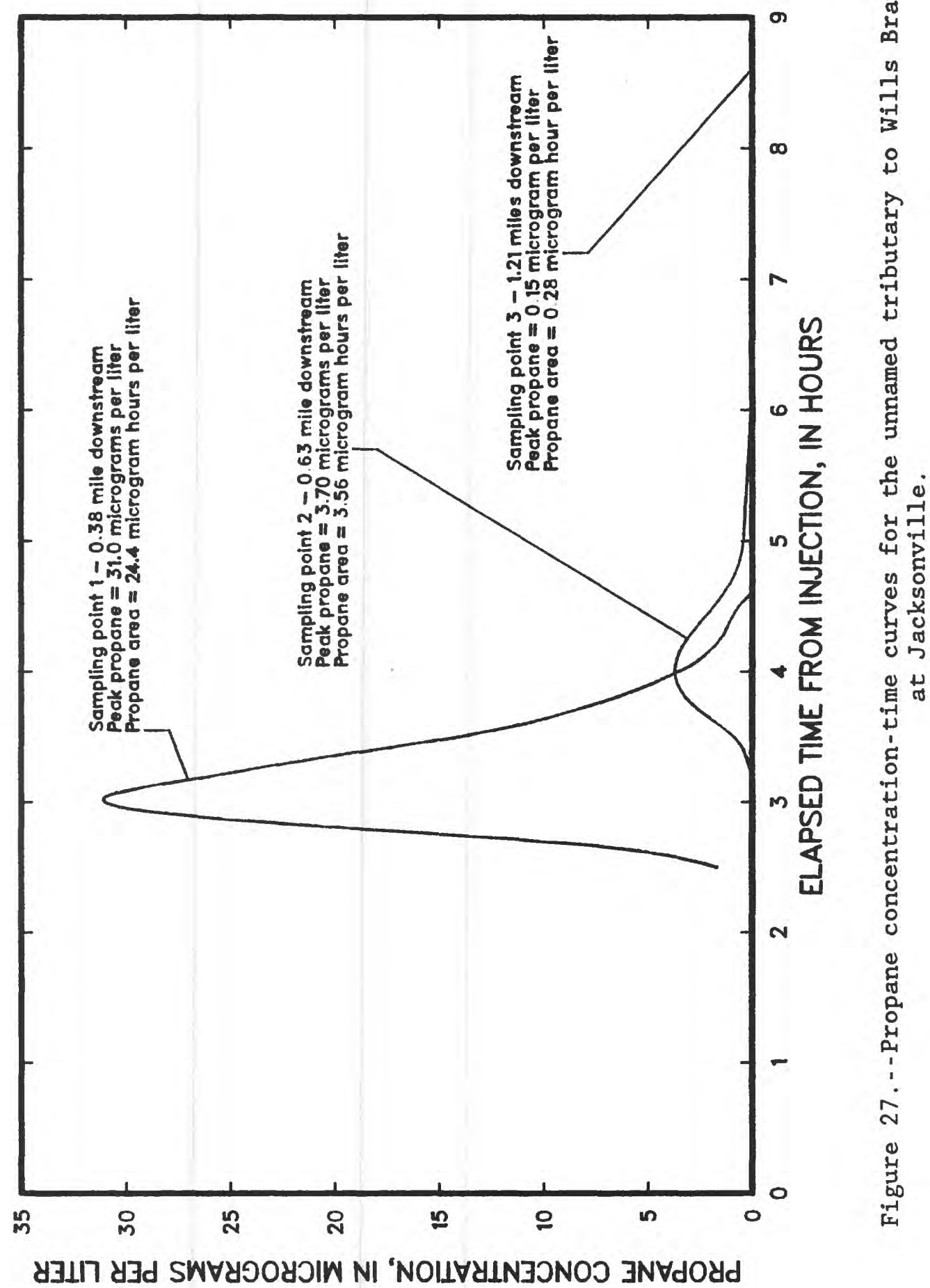


The Peace River is located to the west of the city of Arcadia and empties into Charlotte Harbor. Subreaches A and B (fig. 28) extend from the bridge west of Brownville, located north of Arcadia, to the State Highway 70 bridge at Arcadia to the bridge at Nocatee. The stream is generally wide and deep with a firm bottom, although there were sections where flow was over sand-covered limestone outcrops and depths of 1.0 foot or less were observed. These subreaches were studied on November 30,1982, and the water temperature was $22.0{ }^{\circ} \mathrm{C}$. Discharge at Arcadia on the day of the study was $350 \mathrm{ft}^{3} / \mathrm{s}$. The 7Q,10 for the Peace River at Arcadia is computed to be 57.0 $\mathrm{ft}^{3} / \mathrm{s}$.

Subreach C (fig. 29) extends from the bridge east of Wauchula to Zolfo Springs. The upper part of this reach tended to be wide and deep as compared to the lower part which was wide and shallow. The streambed was composed of mixed sand and gravel. Water color was considered to be between clear and dark. This subreach was studied on December 1, 1982. Water temperature was $22.0{ }^{\circ} \mathrm{C}$. Discharge at Zolfo Springs on the day of the study was $256 \mathrm{ft}^{3} / \mathrm{s}$. The 7Q,10 for the Peace River at Zolfo Springs is computed to be $53.0 \mathrm{ft}^{3} / \mathrm{s}$.

Figures 30 and 31 illustrate the times of travel of the leading edge, peak, and trailing edge of the dye cloud from the injection point to the downstream sample points. Figures $30,31,32$, and 33 show time series data of dye and ethylene concentrations at the sampling points. Reaeration coefficients were determined using ethylene gas only due to the amount of gas required to be injected and the limited number of diffusers. Reaeration coefficients computed from these data are given below. The relatively low values obtained indicate that the greater reactivity of ethylene gas discussed previously was of little or no consequence in these determinations. Consumption of ethylene gas by chemical reactions serves to increase the apparent reaeration coefficient and would be expected to result in higher values than were observed here. The values presented for the Peace River are considered to be among the most accurate and precise determinations performed during the study.

\begin{tabular}{cccc}
\hline Subreach & $\begin{array}{c}\text { Sampling } \\
\text { points }\end{array}$ & $\begin{array}{c}\mathrm{K}_{\mathrm{e}} \\
\text { (days }^{-1} \text { ) }\end{array}$ & $\begin{array}{c}\mathrm{K}_{\mathrm{r}} \\
\text { (days }^{-1} \text { ) }\end{array}$ \\
\hline $\mathrm{A}$ & 1 to 2 & $2.27 \pm 0.15$ & $2.27 \pm 0.15$ \\
$\mathrm{~B}$ & 2 to 3 & $3.55 \pm .23$ & $3.55 \pm .23$ \\
$\mathrm{C}$ & 4 to 5 & $1.90 \pm .33$ & $1.90 \pm .33$
\end{tabular}




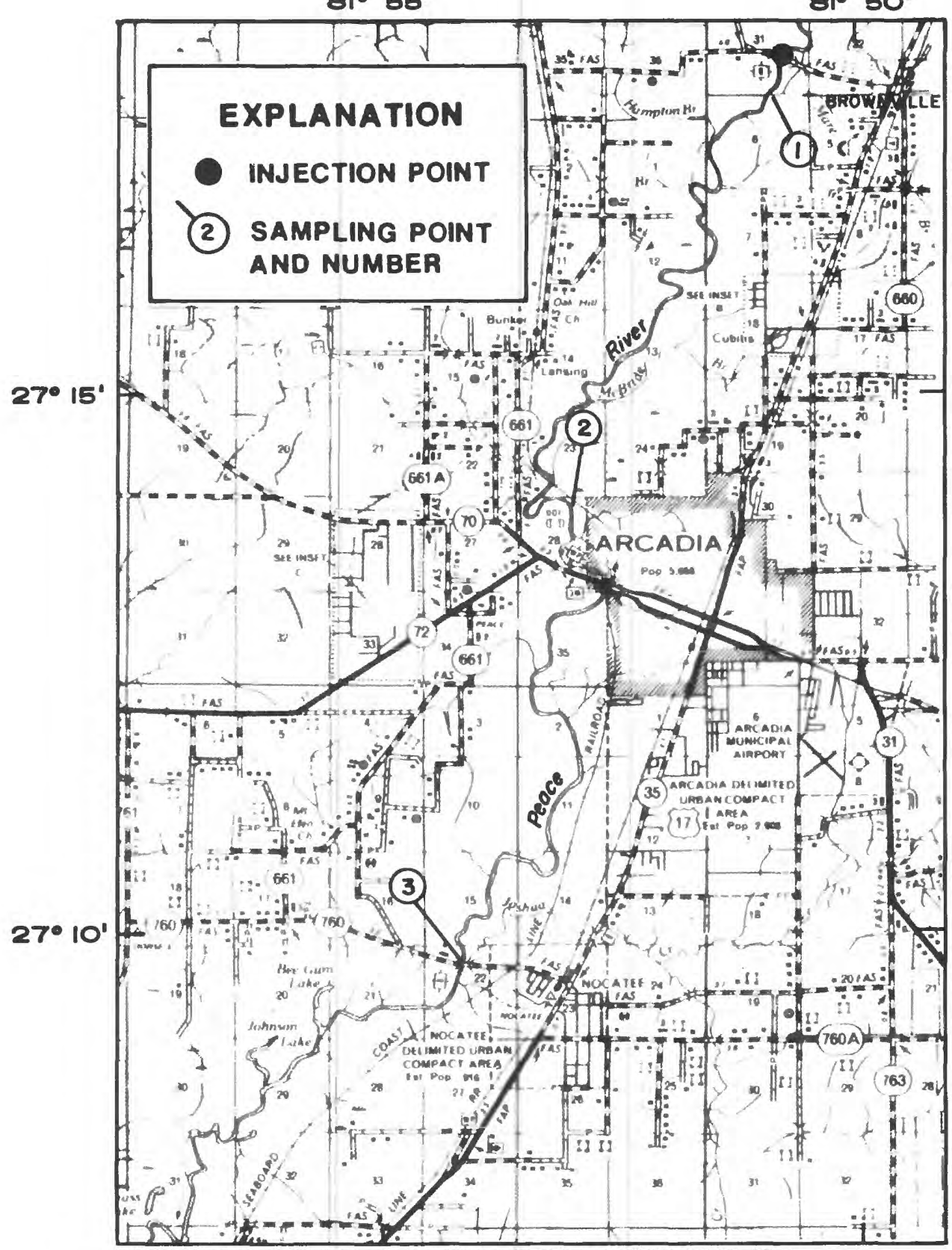

\section{BASE FROM FLORIDA DEPARTMENT OF TRANSPORTATION}

COUNTY HIGHWAY MAP, DESOTO COUNTY 1:126,720, 1971

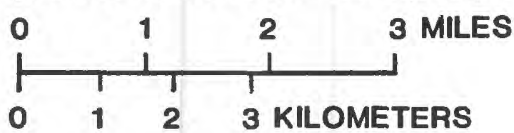

\begin{tabular}{|c|c|c|c|c|c|c|c|c|}
\hline Subreach & Date & $\begin{array}{l}\text { Length } \\
\text { (feet) }\end{array}$ & $\begin{array}{l}\text { Mean } \\
\text { width } \\
\text { (feet) }\end{array}$ & $\begin{array}{l}\text { Mean cross- } \\
\text { sectional } \\
\text { area (square } \\
\text { feet) }\end{array}$ & $\begin{array}{l}\text { Mean } \\
\text { slope } \\
\text { (foot per } \\
\text { foot) }\end{array}$ & $\begin{array}{l}\text { Upstream } \\
\text { discharge } \\
\text { (cubic feet } \\
\text { per second) }\end{array}$ & $\begin{array}{l}\text { Downstream } \\
\text { discharge } \\
\text { (cubic feet } \\
\text { per second) }\end{array}$ & $\begin{array}{l}\text { Time } \\
\text { of } \\
\text { travel } \\
\text { (hours) }\end{array}$ \\
\hline $\begin{array}{l}A-1 \text { to } 2 \\
B-2 \text { to } 3\end{array}$ & $\begin{array}{l}11 / 30 / 82 \\
11 / 30 / 82\end{array}$ & $\begin{array}{l}49,600 \\
32,900\end{array}$ & $\begin{array}{l}116.0 \\
116.0\end{array}$ & $\begin{array}{l}374.0 \\
378.0\end{array}$ & $\begin{array}{c}0.0000865 \\
.000127\end{array}$ & $\begin{array}{l}350 \\
350\end{array}$ & $\begin{array}{l}350 \\
350\end{array}$ & $\begin{array}{r}14.7 \\
9.88\end{array}$ \\
\hline
\end{tabular}

Figure 28.--Location of and hydraulic data for subreaches A and B of the Peace River near Arcadia. 

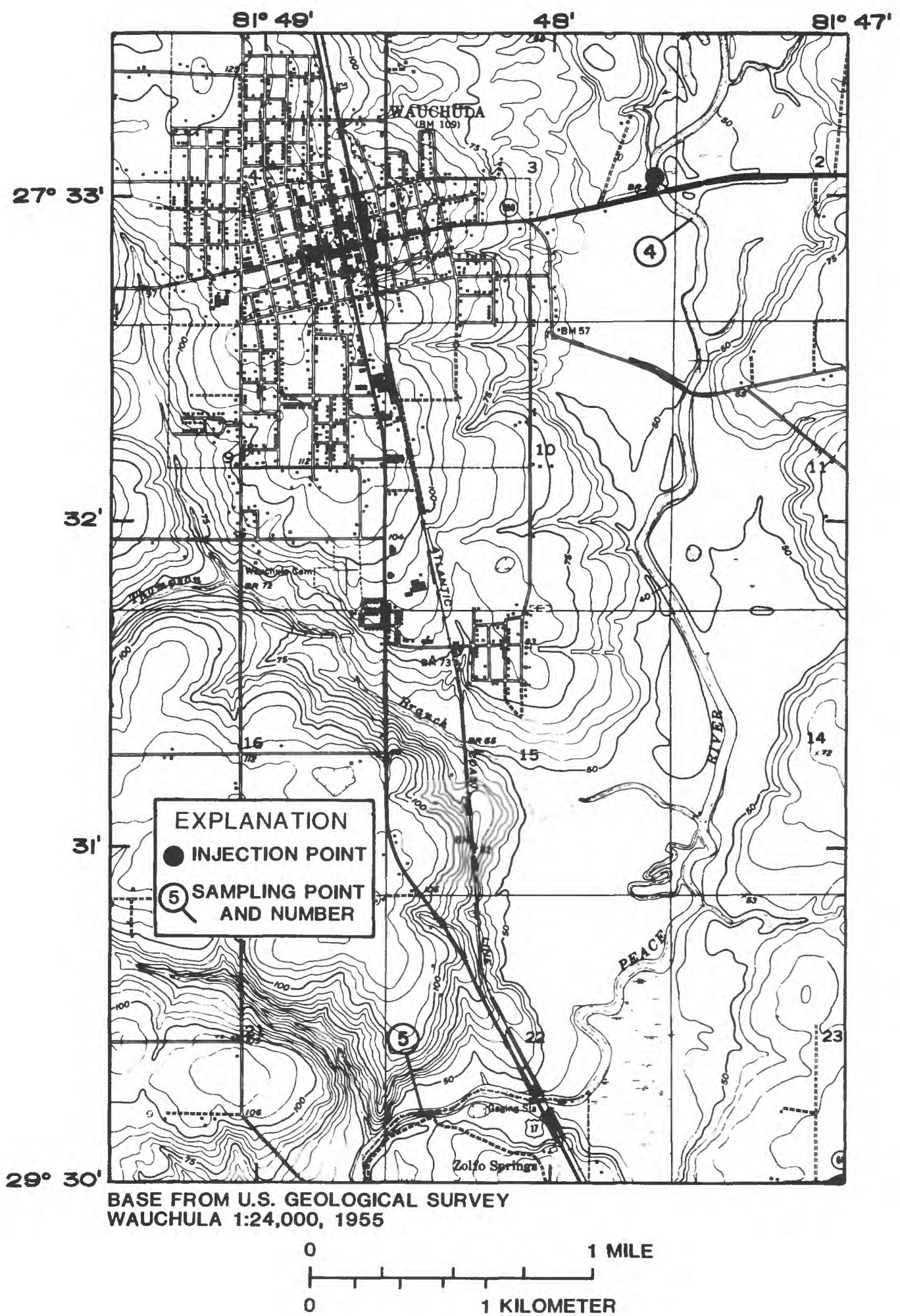

CONTOUR INTERVAL 5 FEET

NATIONAL GEODETIC VERTICAL DATUM OF 1929

\begin{tabular}{lcccccccc}
\hline Subreach & Date & $\begin{array}{c}\text { Length } \\
\text { (feet) }\end{array}$ & $\begin{array}{c}\text { Mean } \\
\text { width } \\
\text { (feet) }\end{array}$ & $\begin{array}{c}\text { Mean cross- } \\
\text { sectional } \\
\text { area (square } \\
\text { feet) }\end{array}$ & $\begin{array}{c}\text { Mean } \\
\text { slope } \\
\text { (foot per } \\
\text { foot) }\end{array}$ & $\begin{array}{c}\text { Upstream } \\
\text { discharge } \\
\text { (cubic feet } \\
\text { per second) }\end{array}$ & $\begin{array}{c}\text { Downstream } \\
\text { discharge } \\
\text { (cubic feet second) } \\
\text { per secon }\end{array}$ & $\begin{array}{c}\text { Time } \\
\text { of } \\
\text { (hours) }\end{array}$ \\
\hline C - 4 to 5 & $12 / 01 / 82$ & 23,200 & 105.0 & 249.0 & 0.000215 & 256 & 256 & 6.25 \\
\hline
\end{tabular}

Figure 29.--Location of and hydraulic data for Subreach $C$ of the Peace River near Arcadia. 

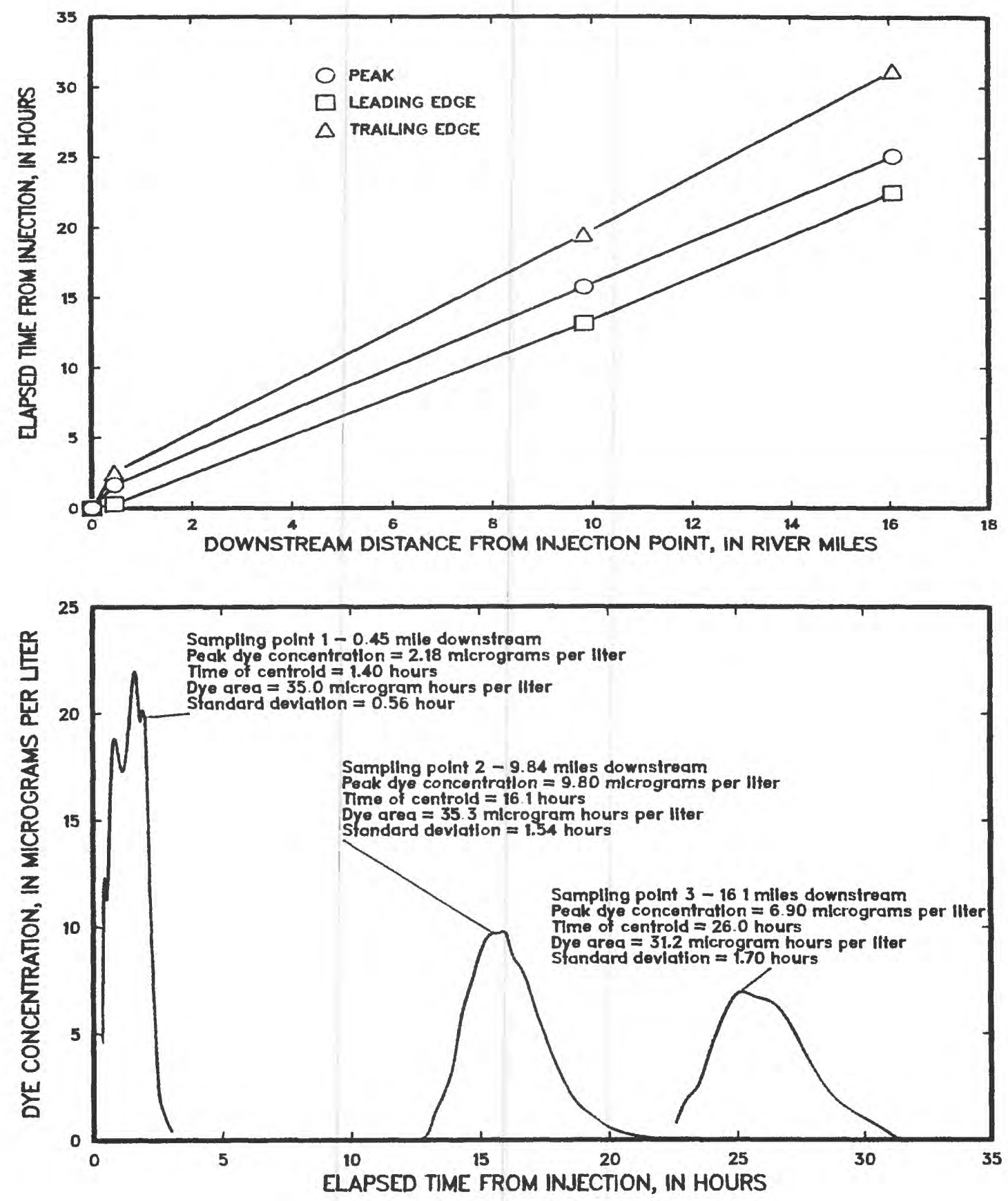

Figure 30.--Traveltime-distance and dye concentration-time curves for subreaches A and B of the Peace River near Arcadia. 

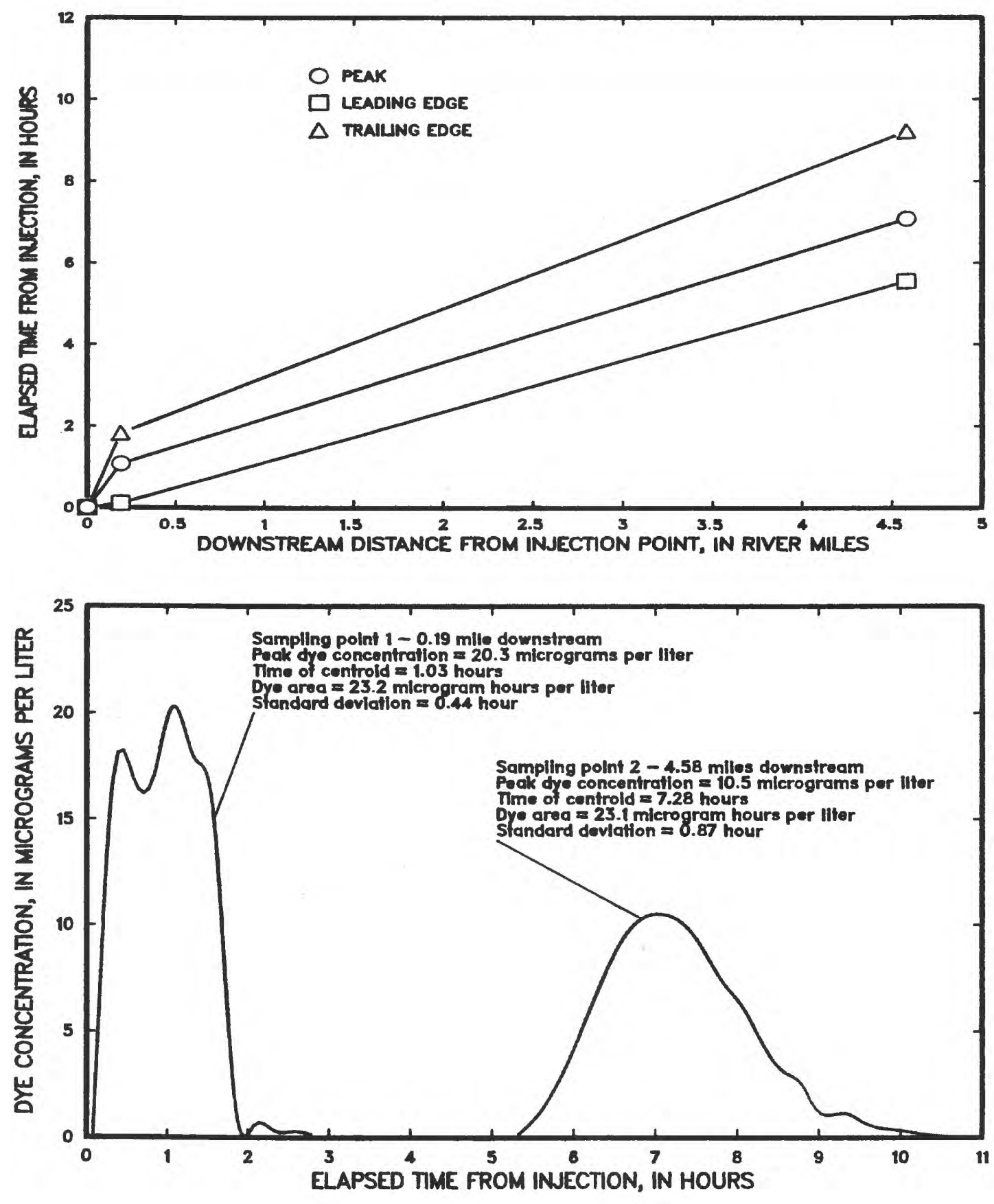

Figure 31.--Traveltime-distance and dye concentration-time curves for subreach $C$ of the Peace River near Arcadia. 


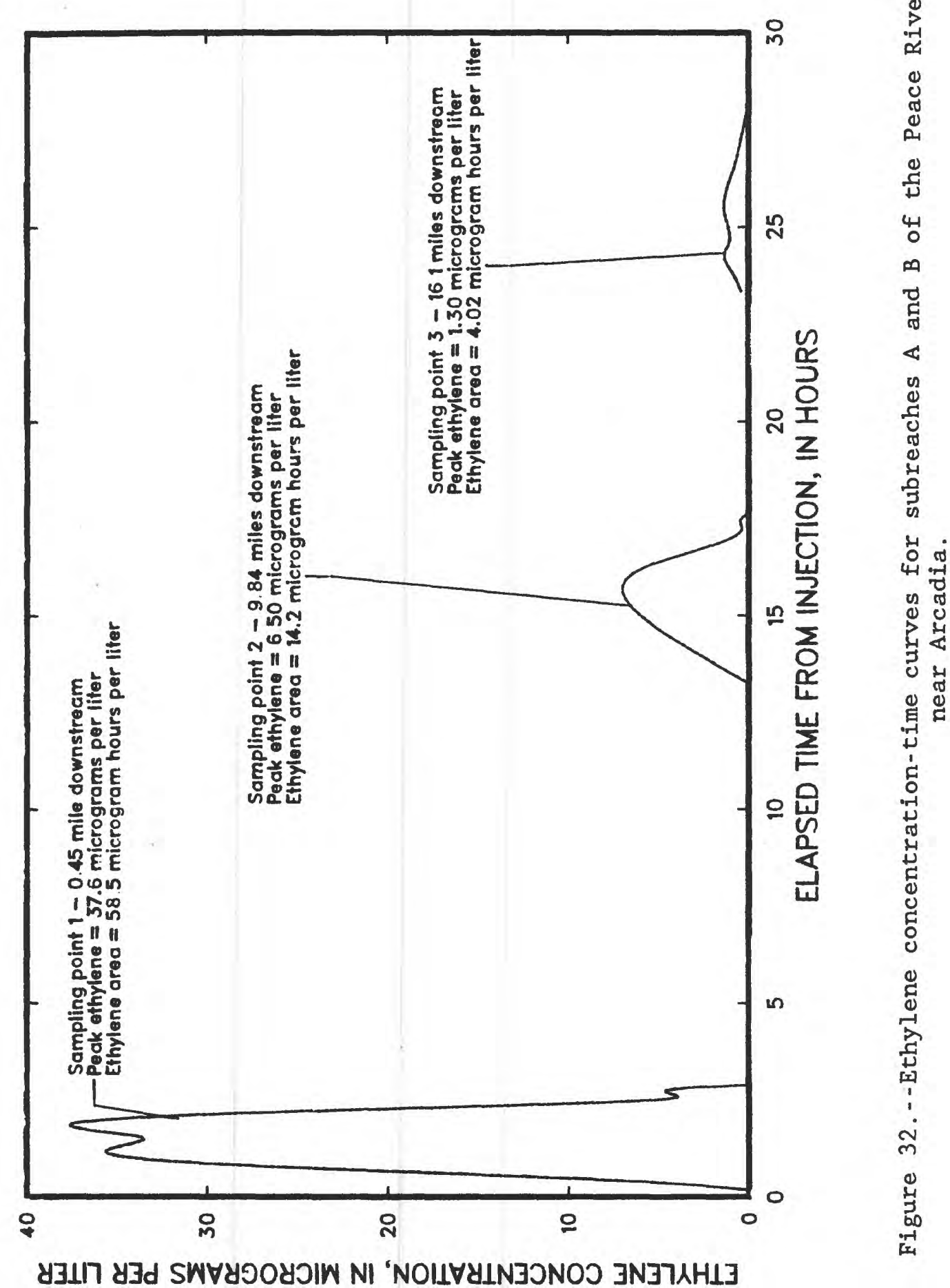




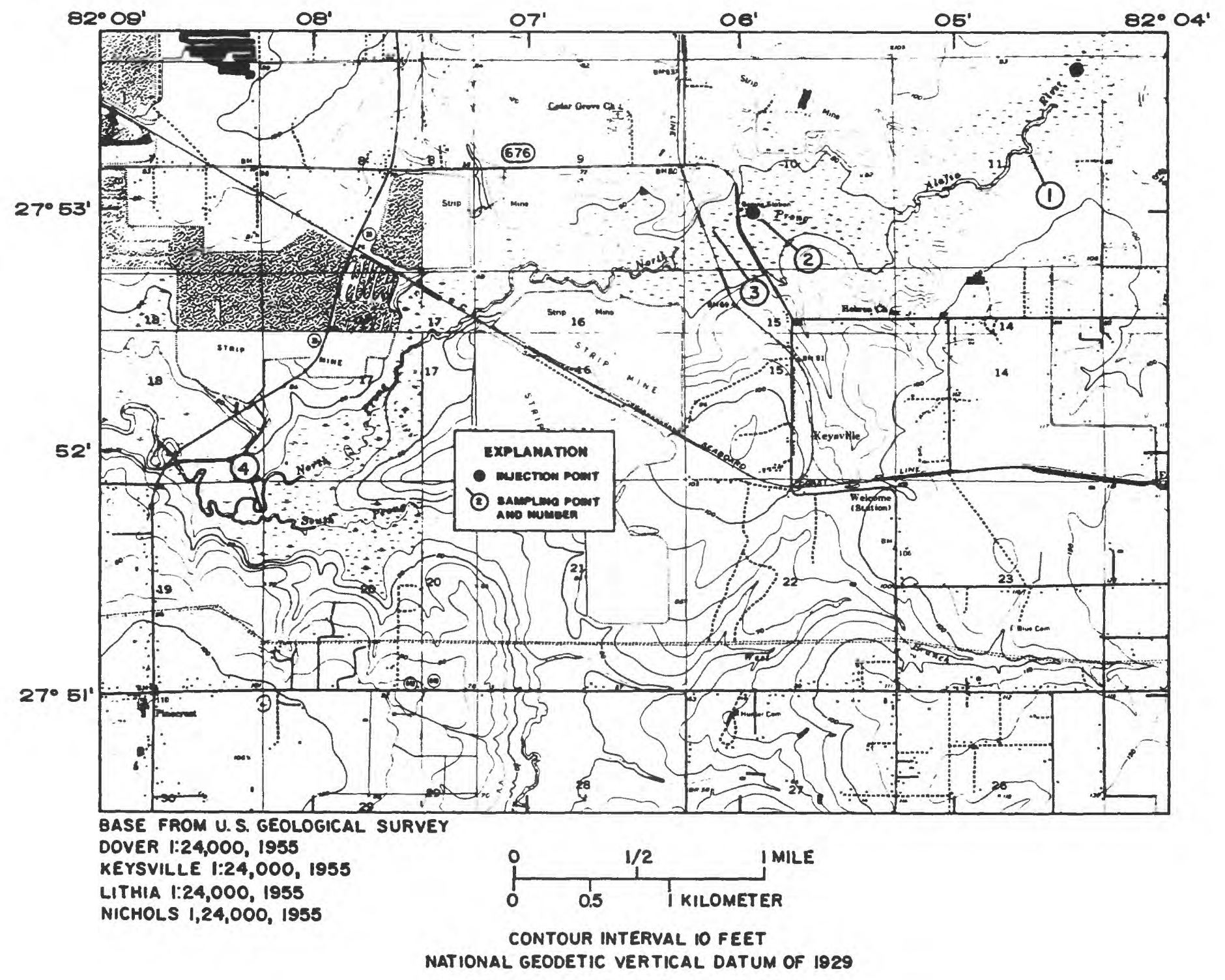

\begin{tabular}{lcccccccc}
\hline Subreach & Date & $\begin{array}{c}\text { Length } \\
\text { (feet) }\end{array}$ & $\begin{array}{c}\text { Mean } \\
\text { width } \\
\text { (feet) }\end{array}$ & $\begin{array}{c}\text { Mean cross- } \\
\text { sectional } \\
\text { area (square } \\
\text { feet) }\end{array}$ & $\begin{array}{c}\text { Mean } \\
\text { slope } \\
\text { (foot per } \\
\text { foot) }\end{array}$ & $\begin{array}{c}\text { Upstream } \\
\text { discharge } \\
\text { (cubic feet } \\
\text { per second) }\end{array}$ & $\begin{array}{c}\text { Downstream } \\
\text { discharge } \\
\text { (cubic feet } \\
\text { per second) }\end{array}$ & $\begin{array}{c}\text { Time } \\
\text { of } \\
\text { trave1 } \\
\text { (hours) }\end{array}$ \\
\hline A - 1 to 2 & $05 / 20 / 85$ & 9,000 & 22.5 & 79.4 & 0.00111 & 12.4 & 12.5 & 16.0 \\
B-3 to 4 & $05 / 21 / 85$ & 21,120 & 24.8 & 47.2 & .000473 & 11.6 & 15.6 & 20.4 \\
\hline
\end{tabular}

Figure 34.--Location of and hydraulic data for the North Prong Alafia River at Keysville. 

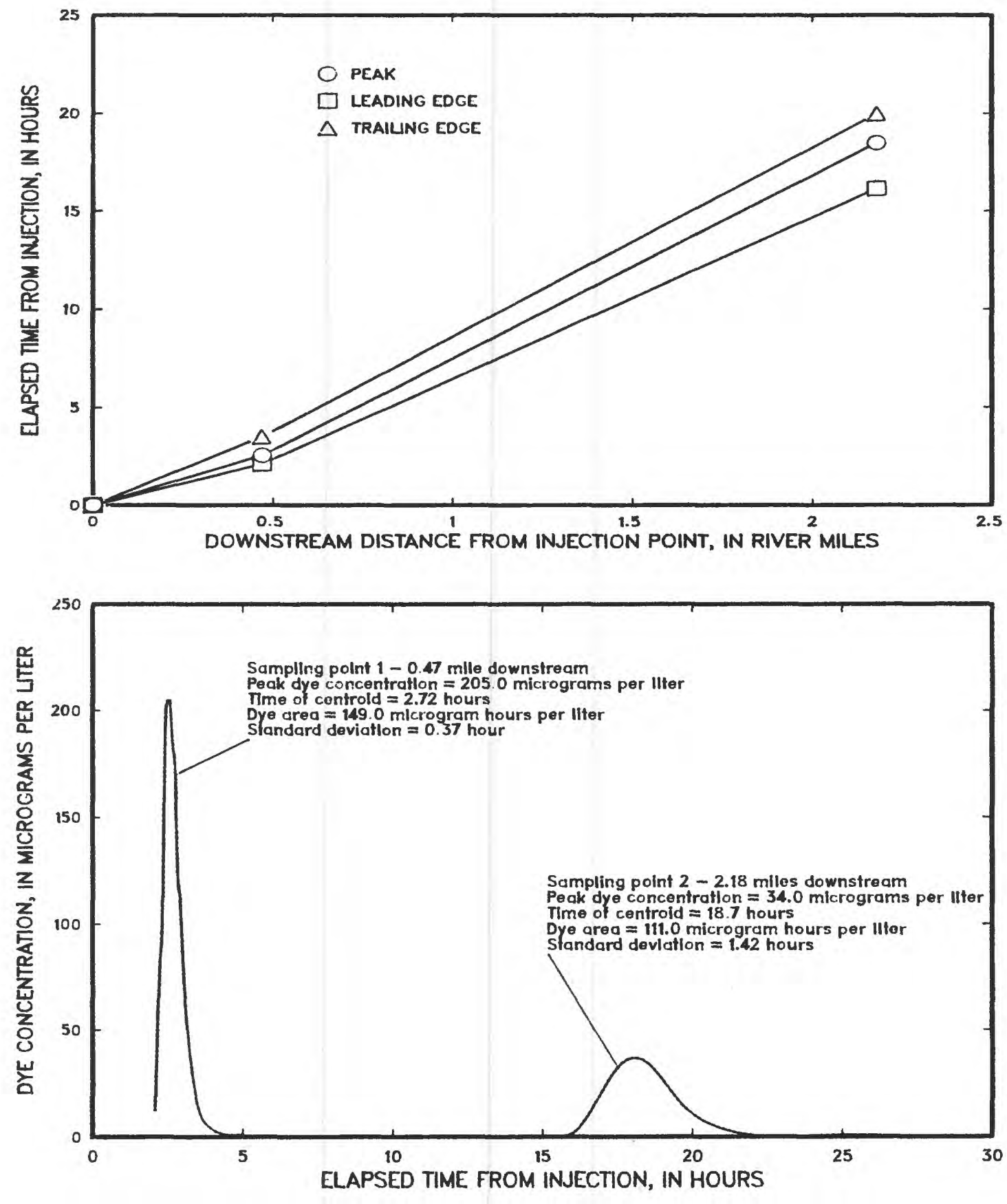

Figure 35.--Traveltime-distance and dye concentration-time curves for subreach A of the North Prong Alafia River at Keysville. 


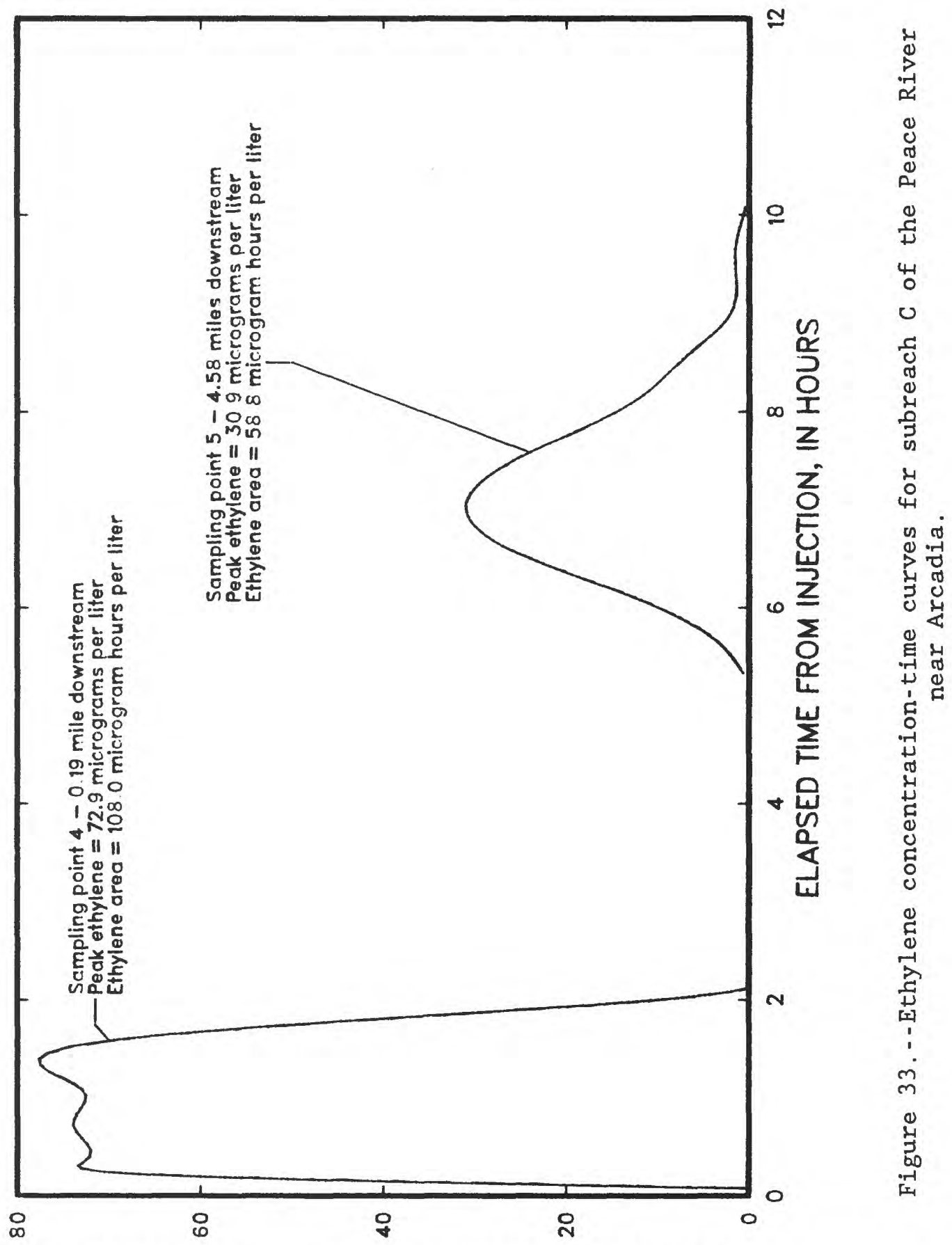

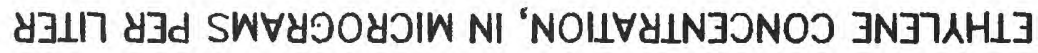




\section{Steady State Method}

Al1 reaeration coefficient measurements performed after June 1984 utilized the steady-state method (Yotsukura and others, 1983) with propane as the tracer. These measurements were made on the North and South Prongs of the Alafia River, the Withlacoochee River near Bellville, Silversmith Creek at Jacksonville, an unnamed tributary to Christopher Creek at Jacksonville, and Strawberry Creek at Jacksonville.

\section{North Prong Alafia River at Keysville}

The test reaches on the North Prong of the Alafia River are located to the north of Keysville. Subreach A (fig. 34) is located upstream of SR 676. Stream velocities through this subreach were very sluggish due to pooling. Channel width is uniform. The bottom is a soft sand with some rock outcrops. Subreach A was studied on May 20, 1985, when the water temperature was $26.0{ }^{\circ} \mathrm{C}$.

Subreach B (fig. 34) extends from 500 feet below SR 676 to a point above the confluence with the South Prong at Aldermans Ford State Park. The flow is through pools and riffles in the upper part and tranquil in the lower. Channel width is generally uniform. Bottom material is a firm sand with grave1. Subreach B was studied on May 21, 1985, when the water temperature was $28.5{ }^{\circ} \mathrm{C}$. Discharges averaged $12.5 \mathrm{ft}^{3} / \mathrm{s}$ for subreach $\mathrm{A}$ and $13.6 \mathrm{ft}^{3} / \mathrm{s}$ for subreach B. The 7Q,10 for the North Prong Alafia River at Keysville is computed to be $11.0 \mathrm{ft}^{3} / \mathrm{s}$.

Figures 35 and 36 illustrate the times of travel of the leading edge, peak, and trailing edge of the dye cloud from the injection points to the downstream sample points and time series data of dye concentrations at the sampling points. Steady state propane concentrations at the sampling points and the computed reaeration coefficients are given below.

\begin{tabular}{ccccc}
\hline Subreach & $\begin{array}{c}\text { Sampling } \\
\text { points }\end{array}$ & $\begin{array}{c}\text { Upstream } \\
\text { propane } \\
\text { concentration } \\
(\mu \mathrm{g} / \mathrm{L})\end{array}$ & $\begin{array}{c}\text { Downstream } \\
\text { propane } \\
\text { concentration } \\
(\mu \mathrm{g} / \mathrm{L})\end{array}$ & $\mathrm{K}_{\mathrm{r}}$ \\
\hline A & 1 to 2 & 71.4 & 24.8 & $2.77 \pm 0.10$ \\
B & 3 to 4 & 56.4 & 5.3 & $1.90 \pm .12$
\end{tabular}



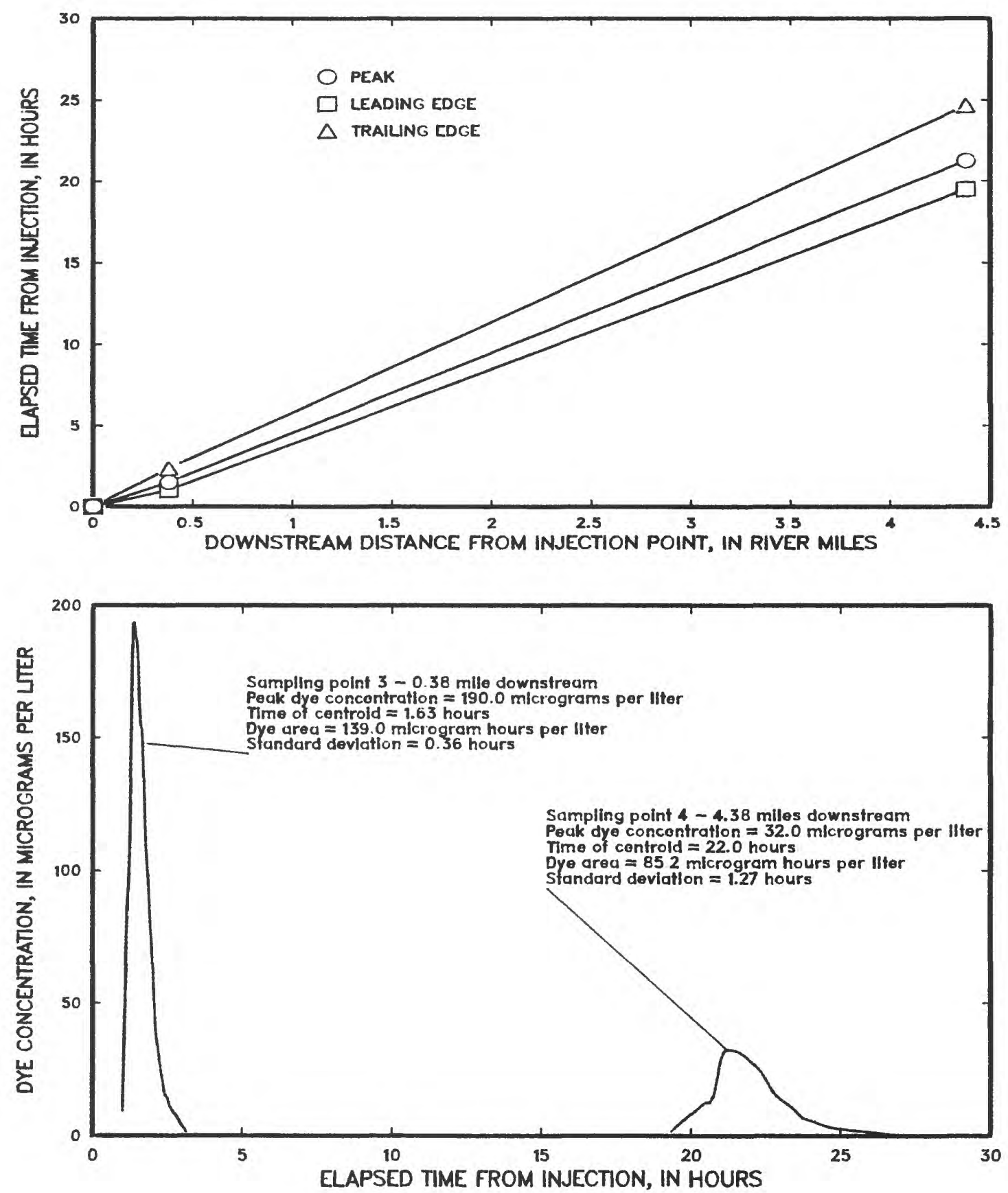

Figure 36.--Trave1time-distance and dye concentration-time curves for subreach B of the North Prong Alafia River at Keysville. 
South Prong Alafia River near Pinecrest

The study reach on the South Prong of the Alafia River (fig. 37) is located to the northeast of Pinecrest and extends from SR 640 to a point above the confluence with the North Prong at Aldermans Ford State Park. The channel was of uniform width and relatively shallow. The bottom consists of a loosely packed sand. Velocities are fairly uniform and little pooling was noted. The study was conducted on May 22, 1985, when the water temperature was $26.0{ }^{\circ} \mathrm{C}$. Discharge on the day of the study averaged $3.0 \mathrm{ft}^{3} / \mathrm{s}$. The $7 \mathrm{Q}, 10$ for the South Prong Alafia River near Pinecrest is computed to be $2.9 \mathrm{ft}^{3} / \mathrm{s}$.

Figure 38 illustrates the times of travel of the leading edge, peak, and trailing edge of the dye cloud from the injection point to the downstream sample point, and time series data of dye concentrations at the sample points. Steady state propane concentrations and the reaeration coefficient for the subreach are given below.

\begin{tabular}{ccccc}
\hline Subreach & $\begin{array}{c}\text { Sampling } \\
\text { points }\end{array}$ & $\begin{array}{c}\text { Upstream } \\
\text { propane } \\
\text { concentration } \\
(\mu \mathrm{g} / \mathrm{L})\end{array}$ & $\begin{array}{c}\text { Downstream } \\
\text { propane } \\
\text { concentration } \\
(\mu \mathrm{g} / \mathrm{L})\end{array}$ & $\mathrm{K}_{\mathrm{r}}$ \\
\hline A & 1 to 2 & 113.0 & 1.0 & $5.17 \pm 0.15$
\end{tabular}




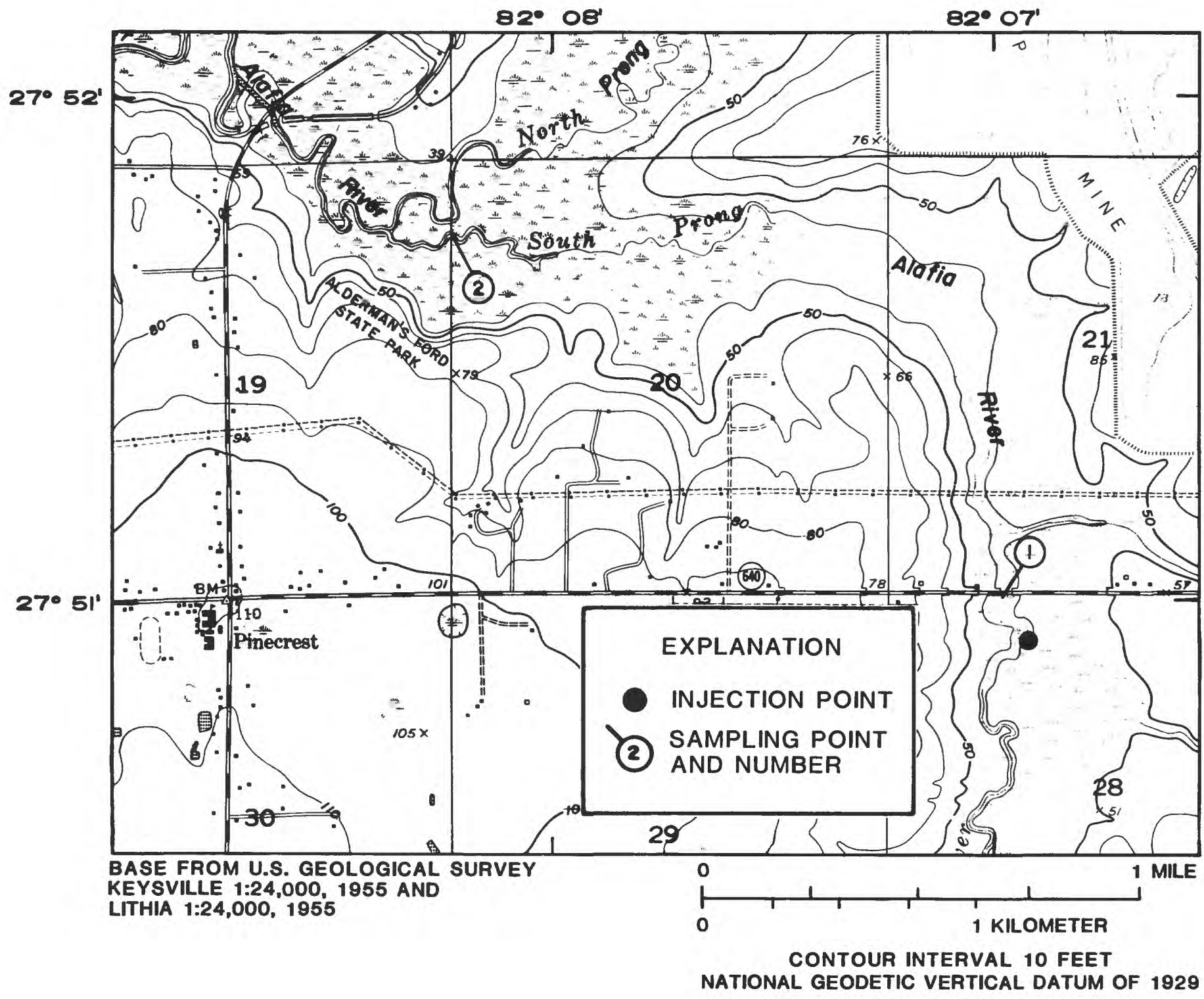

\begin{tabular}{lcccccccc}
\hline Subreach & Date & $\begin{array}{c}\text { Length } \\
\text { (feet) }\end{array}$ & $\begin{array}{c}\text { Mean } \\
\text { width } \\
\text { (feet) }\end{array}$ & $\begin{array}{c}\text { Mean cross- } \\
\text { sectional } \\
\text { area (square } \\
\text { feet) }\end{array}$ & $\begin{array}{c}\text { Mean } \\
\text { slope } \\
\text { (foot per } \\
\text { foot) }\end{array}$ & $\begin{array}{c}\text { Upstream } \\
\text { discharge } \\
\text { (cubic feet } \\
\text { per second) }\end{array}$ & $\begin{array}{c}\text { Downstream } \\
\text { discharge } \\
\text { pubic feet second) }\end{array}$ & $\begin{array}{c}\text { Time } \\
\text { of } \\
\text { travel } \\
\text { (hours) }\end{array}$ \\
\hline A- 1 to 2 & $05 / 22 / 85$ & 12,000 & 17.8 & 24.5 & 0.000555 & 3.16 & 2.98 & 26.6 \\
\hline
\end{tabular}

Figure 37.--Location of and hydraulic data for the South Prong Alafia River near Pinecrest. 

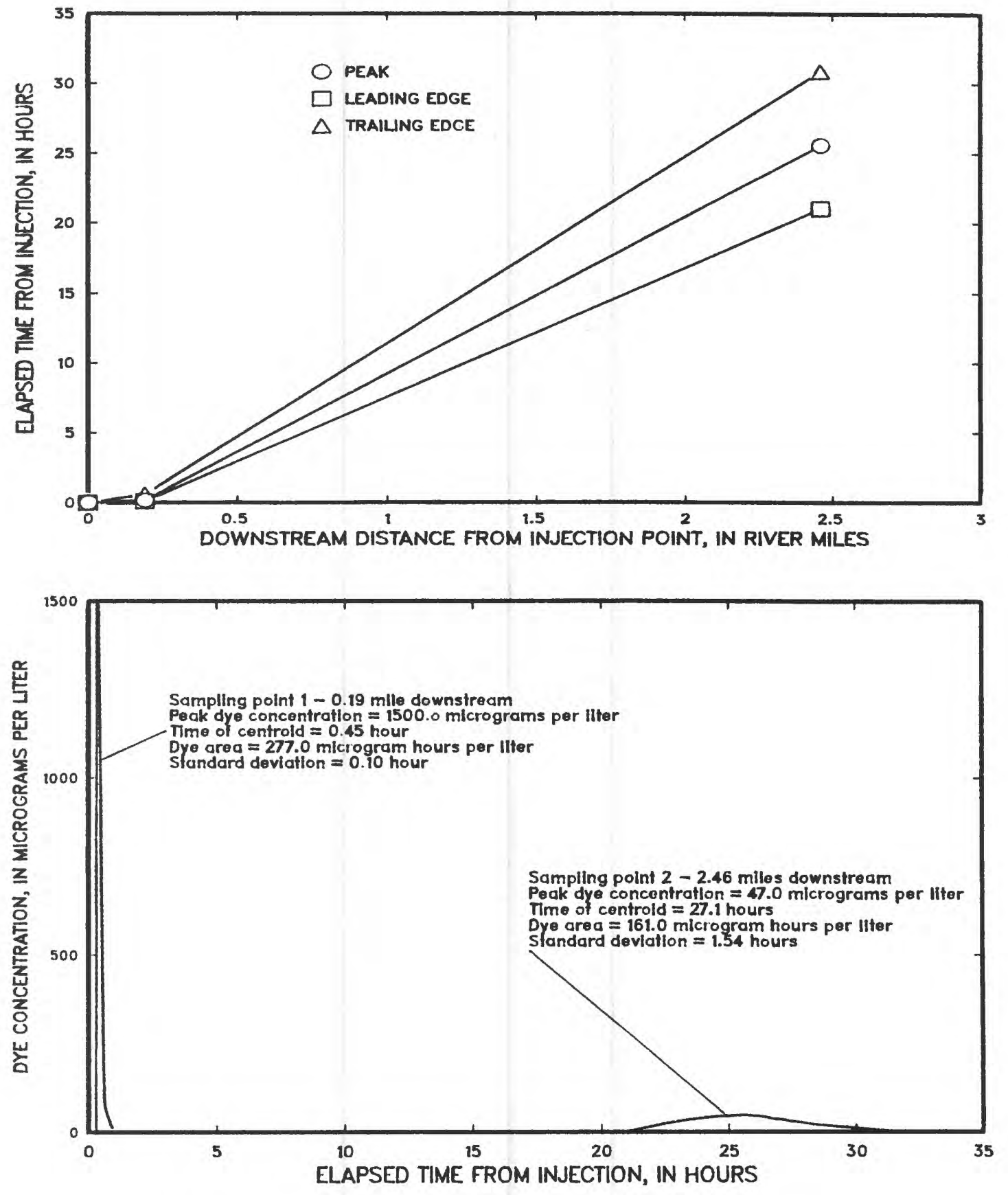

Figure 38.--Traveltime-distance and dye concentration-time curves for the South Prong Alafia River near Pinecrest. 


\section{Withlacoochee River near Bellville}

The Withlacoochee River is located to the east of the town of Bellville and is a tributary of the Suwannee River. Subreach C (fig. 39) was studied on October 23,1984 , when the water temperature was $23.0{ }^{\circ} \mathrm{C}$. This subreach extends from the bridge at Bellville to a point approximately 0.75 mile downstream. Velocities in the reach were very low. Water color is very dark due in part to effluent from a paper company at Jumping Gully Creek approximately 2.0 miles upstream. There were no exposed shoals in this study reach.

Subreaches A and B (fig. 39) were studied on October 24, 1984, when the water temperature was $23.0^{\circ} \mathrm{C}$. These subreaches start approximately 150 feet above the paper company outfall at Jumping Gully Creek to a point approximately 1.2 miles downstream. The upper part of this section is narrow, deep, and sluggish then widens and shallows. The lower part of this reach contains several small and one large limestone shoal with an approximate change in elevation of about 5.0 feet over a distance of approximately 500 feet. Effluent from the paper company enters in the upper part.

Discharge during the study for subreaches $A$ and $B$ was $194 \mathrm{ft}^{3} / \mathrm{s}$. Discharge during the study of subreach $C$ was $197 \mathrm{ft}^{3} / \mathrm{s}$. The 7Q,10 for the Withlacoochee River at Bellville is computed to be $95.0 \mathrm{ft}^{3} / \mathrm{s}$.

Figures 40 and 41 illustrate the times of travel of the leading edge, peak, and trailing edge of the dye cloud from the injection points to the downstream sample points, and time series data of dye concentrations at the sampling points. Steady state propane concentrations at the sampling points and the computed reaeration coefficients for each subreach are given below.

\begin{tabular}{cccccc}
\hline Subreach & $\begin{array}{c}\text { Sampling } \\
\text { points }\end{array}$ & Date & $\begin{array}{c}\text { Upstream } \\
\text { propane } \\
\text { concentration } \\
(\mu \mathrm{g} / \mathrm{L})\end{array}$ & $\begin{array}{c}\text { Downstream } \\
\text { propane } \\
\text { concentration } \\
(\mu \mathrm{g} / \mathrm{L})\end{array}$ & $\mathrm{K}_{\mathrm{r}}$ \\
\hline & 1 to 2 & $10 / 24 / 84$ & 3.7 & 1.64 & $6.37 \pm 3.18$ \\
days $^{-1}$ )
\end{tabular}




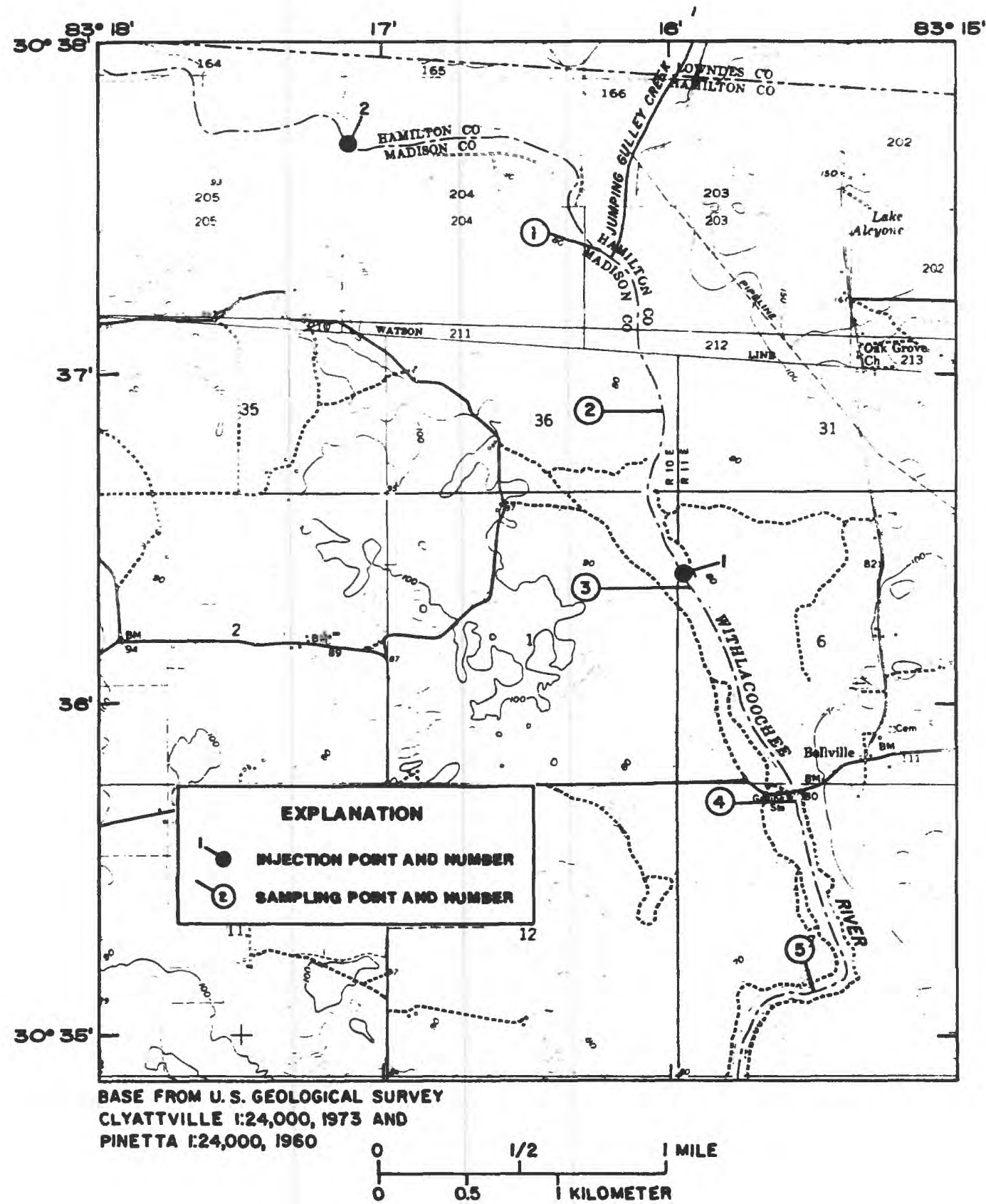

CONTOUR INTERVAL 10 FEET

NATIONAL GEODETIC VERTICAL DATUM OF 192

\begin{tabular}{|c|c|c|c|c|c|c|c|c|}
\hline Subreach & Date & $\begin{array}{l}\text { Length } \\
\text { (feet) }\end{array}$ & $\begin{array}{l}\text { Mean } \\
\text { width } \\
\text { (feet) }\end{array}$ & $\begin{array}{l}\text { Mean cross- } \\
\text { sectional } \\
\text { area (square } \\
\text { feet) }\end{array}$ & $\begin{array}{l}\text { Mean } \\
\text { slope } \\
\text { (foot per } \\
\text { foot) }\end{array}$ & $\begin{array}{l}\text { Upstream } \\
\text { discharge } \\
\text { (cubic feet } \\
\text { per second) }\end{array}$ & $\begin{array}{l}\text { Downstream } \\
\text { discharge } \\
\text { (cubic feet } \\
\text { per second) }\end{array}$ & $\begin{array}{l}\text { Time } \\
\text { of } \\
\text { travel } \\
\text { (hours) }\end{array}$ \\
\hline $\begin{array}{l}A=1 \text { to } 2 \\
B=2 \text { to } 3 \\
C=4 \text { to } 5\end{array}$ & $\begin{array}{l}10 / 24 / 84 \\
10 / 24 / 84 \\
10 / 23 / 84\end{array}$ & $\begin{array}{l}3,200 \\
3,500 \\
3,800\end{array}$ & $\begin{array}{l}146.5 \\
155.0 \\
159.0\end{array}$ & $\begin{array}{l}871.0 \\
943.0 \\
791.0\end{array}$ & $\begin{array}{r}0.00020 \\
.000189 \\
.000189\end{array}$ & $\begin{array}{l}194.0 \\
194.0 \\
197.0\end{array}$ & $\begin{array}{l}194.0 \\
194.0 \\
197.0\end{array}$ & $\begin{array}{l}3.99 \\
4.73 \\
4.24\end{array}$ \\
\hline
\end{tabular}

Figure 39.--Location of and hydraulic data for the Withlacoochee River near Bellville. 

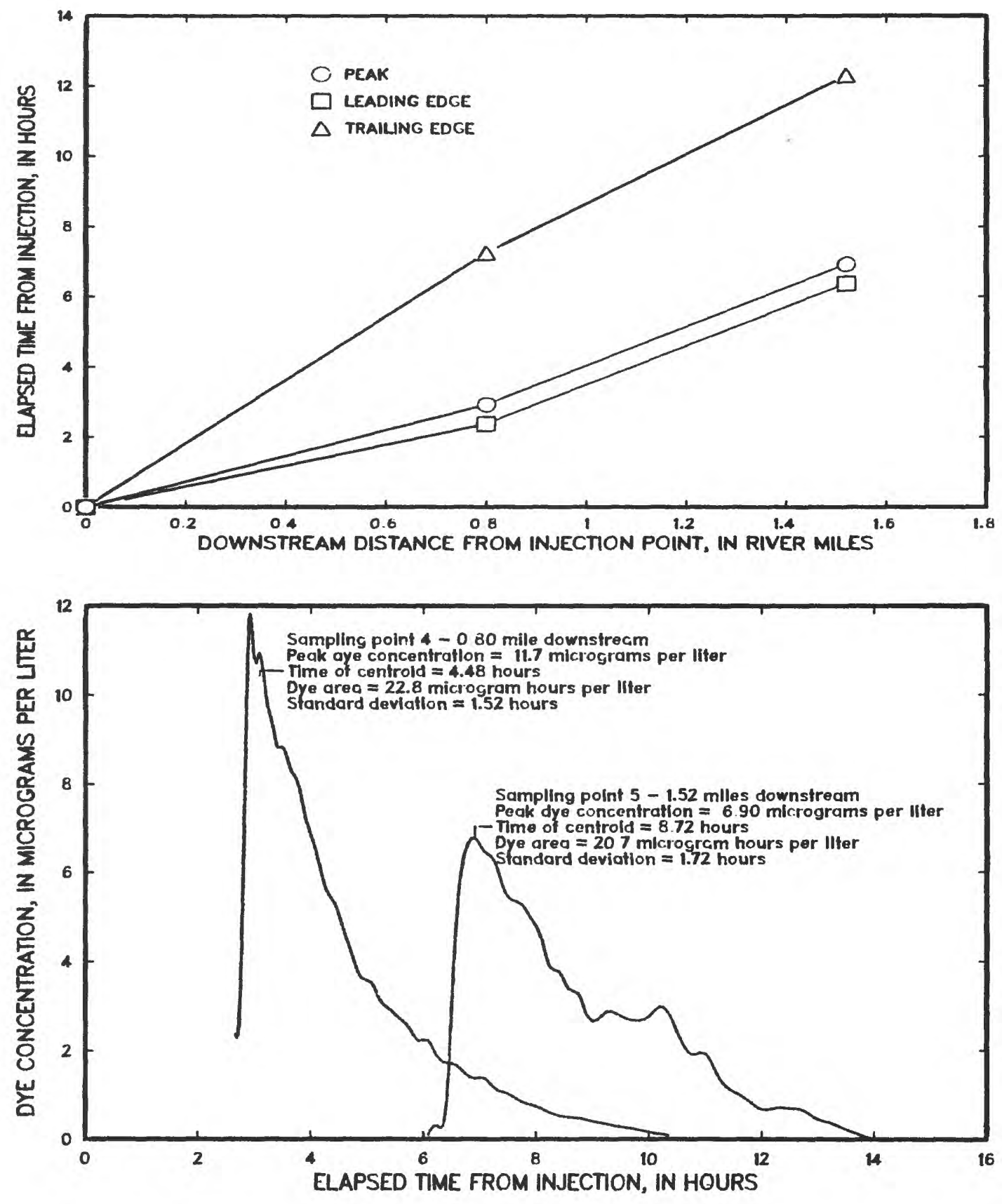

Figure 40.--Traveltime-distance and dye concentration-time curves for subreaches A and B of the Withlacoochee River near Bellville. 

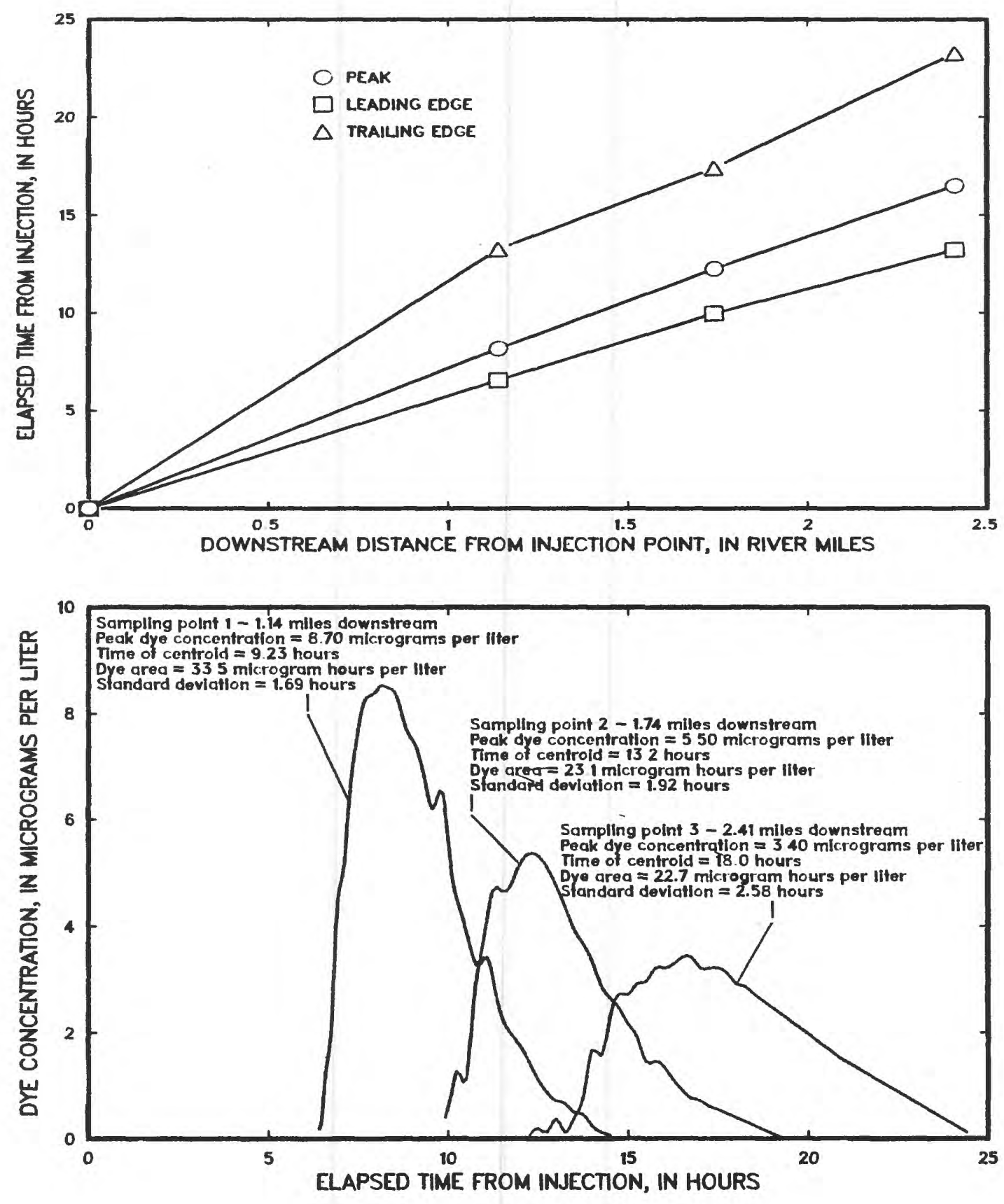

Figure 41.--Traveltime-distance and dye concentration-time curves for subreach $C$ of the Withlacoochee River near Bellville. 
Silversmith Creek (fig. 42) is located south of Atlantic Boulevard in Jacksonville. Drainage upstream of the study reach is into a detention pond. The study reach begins about 50 feet below the detention pond outfall and extends to the bridge on Arlington Road. Channel conditions alternate between dredged and natural. Where conditions are natural, pooling exists due to debris in the channel. Water color is clear. Silversmith Creek was studied over the same subreach on both August 14, 1984, and on May 29, 1985. During the August measurement, the discharge averaged $0.54 \mathrm{ft} / \mathrm{s}$ and the water temperature was $27.5^{\circ} \mathrm{C}$. During the May measurement, discharge averaged $0.59 \mathrm{ft}^{3} / \mathrm{s}$ and the water temperature was $28.0{ }^{\circ} \mathrm{C}$. The nearest long-term station for which low-flow frequencies were available was the Ortega River at Jacksonville. Discharges for the Ortega River at Jacksonville on the days Silversmith Creek was studied were 1.3 and 1.2 $\mathrm{ft}^{3} / \mathrm{s}$. The $7 \mathrm{Q}, 10$ for the Ortega is computed to be $0.47 \mathrm{ft}^{3} / \mathrm{s}$.

Figures 43 and 44 illustrate the times of travel of the leading edge, peak, and trailing edge of the dye cloud from the injection point to the downstream sample point and time series data for dye concentrations at the sampling points. Steady state propane concentrations at the sampling sites and computed reaeration coefficients for both studies are given below.

\begin{tabular}{cccccc}
\hline Subreach & $\begin{array}{c}\text { Sampling } \\
\text { points }\end{array}$ & Date & $\begin{array}{c}\text { Upstream } \\
\text { propane } \\
\text { concentration } \\
(\mu \mathrm{g} / \mathrm{L})\end{array}$ & $\begin{array}{c}\text { Downstream } \\
\text { propane } \\
\text { concentration } \\
(\mu \mathrm{g} / \mathrm{L})\end{array}$ & $\mathrm{K}_{\mathrm{r}}$ \\
\hline & 1 to 2 & $08 / 14 / 84$ & 684.0 & 70.2 & $12.8 \pm 1.2$ \\
$\mathrm{~A}$ & 1 to 2 & $05 / 29 / 85$ & 383.0 & 33.7 & $15.1 \pm 1.5$
\end{tabular}




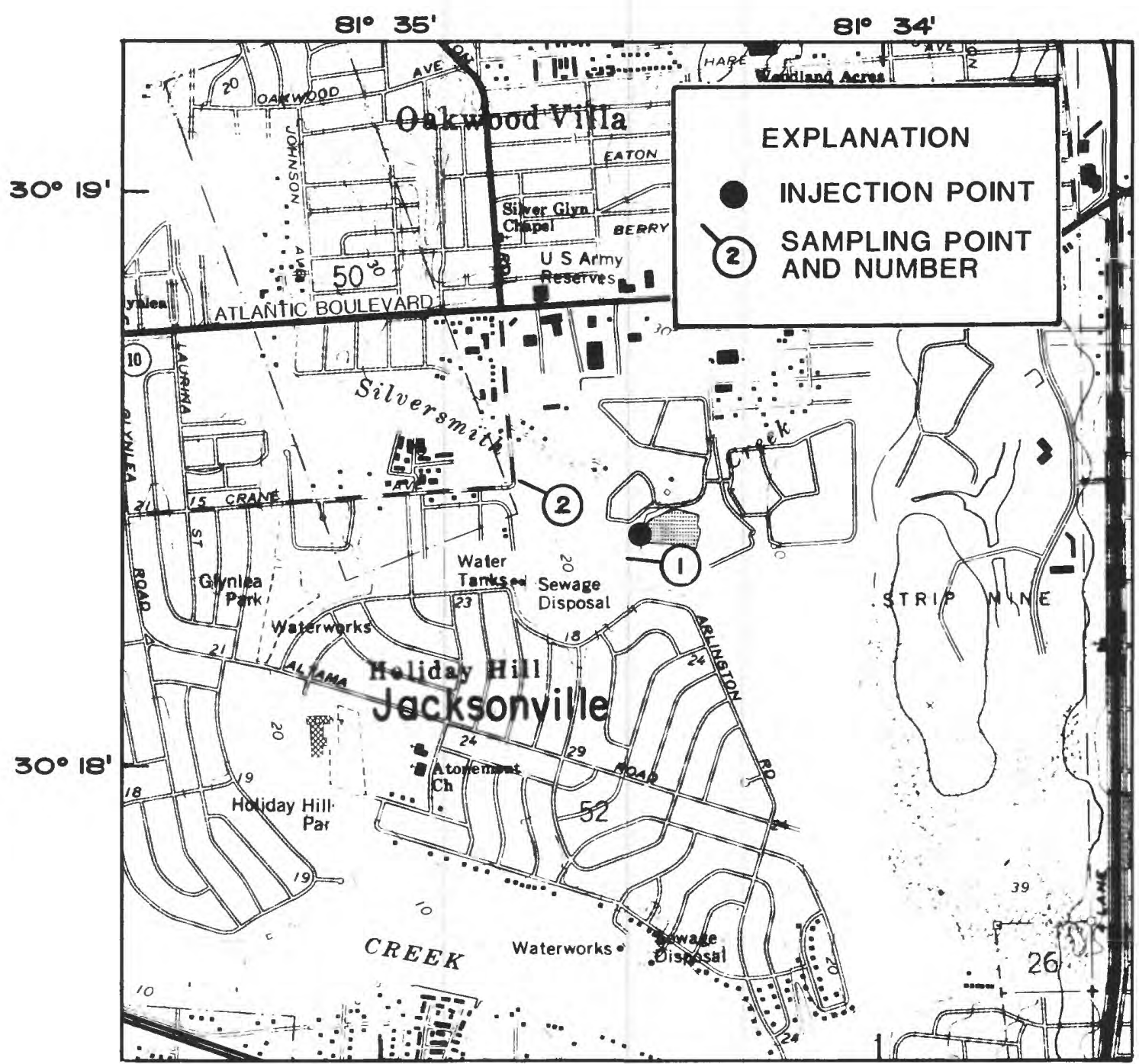

BASE FROM U.S. GEOLOGICAL SURVEY

ARLINGTON 1:24,000, 1964

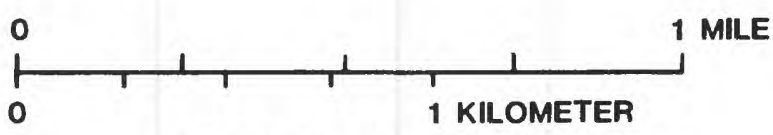

CONTOUR INTERVAL 5 FEET

NATIONAL GEODETIC VERTICAL DATUM OF 1929

\begin{tabular}{|c|c|c|c|c|c|c|c|c|}
\hline Subreach & Date & $\begin{array}{l}\text { Length } \\
\text { (feet) }\end{array}$ & $\begin{array}{l}\text { Mean } \\
\text { width } \\
\text { (feet) }\end{array}$ & $\begin{array}{l}\text { Mean cross- } \\
\text { sectional } \\
\text { area (square } \\
\text { feet) }\end{array}$ & $\begin{array}{l}\text { Mean } \\
\text { slope } \\
\text { (foot per } \\
\text { foot) }\end{array}$ & $\begin{array}{l}\text { Upstream } \\
\text { discharge } \\
\text { (cubic feet } \\
\text { per second) }\end{array}$ & $\begin{array}{l}\text { Downstream } \\
\text { discharge } \\
\text { (cubic feet } \\
\text { per second) }\end{array}$ & $\begin{array}{l}\text { Time } \\
\text { of } \\
\text { trave1 } \\
\text { (hours) }\end{array}$ \\
\hline $\begin{array}{l}A-1 \text { to } 2 \\
A-1 \text { to } 2\end{array}$ & $\begin{array}{l}08 / 14 / 84 \\
05 / 29 / 85\end{array}$ & $\begin{array}{l}1,200 \\
1,200\end{array}$ & $\begin{array}{l}4.60 \\
5.25\end{array}$ & $\begin{array}{l}6.92 \\
7.92\end{array}$ & $\begin{array}{r}0.00143 \\
.00143\end{array}$ & $\begin{array}{r}0.45 \\
.59\end{array}$ & $\begin{array}{r}0.62 \\
.59\end{array}$ & $\begin{array}{l}4.27 \\
4.48\end{array}$ \\
\hline
\end{tabular}

Figure 42.--Location of and hydraulic data for Silversmith Creek at Jacksonville. 

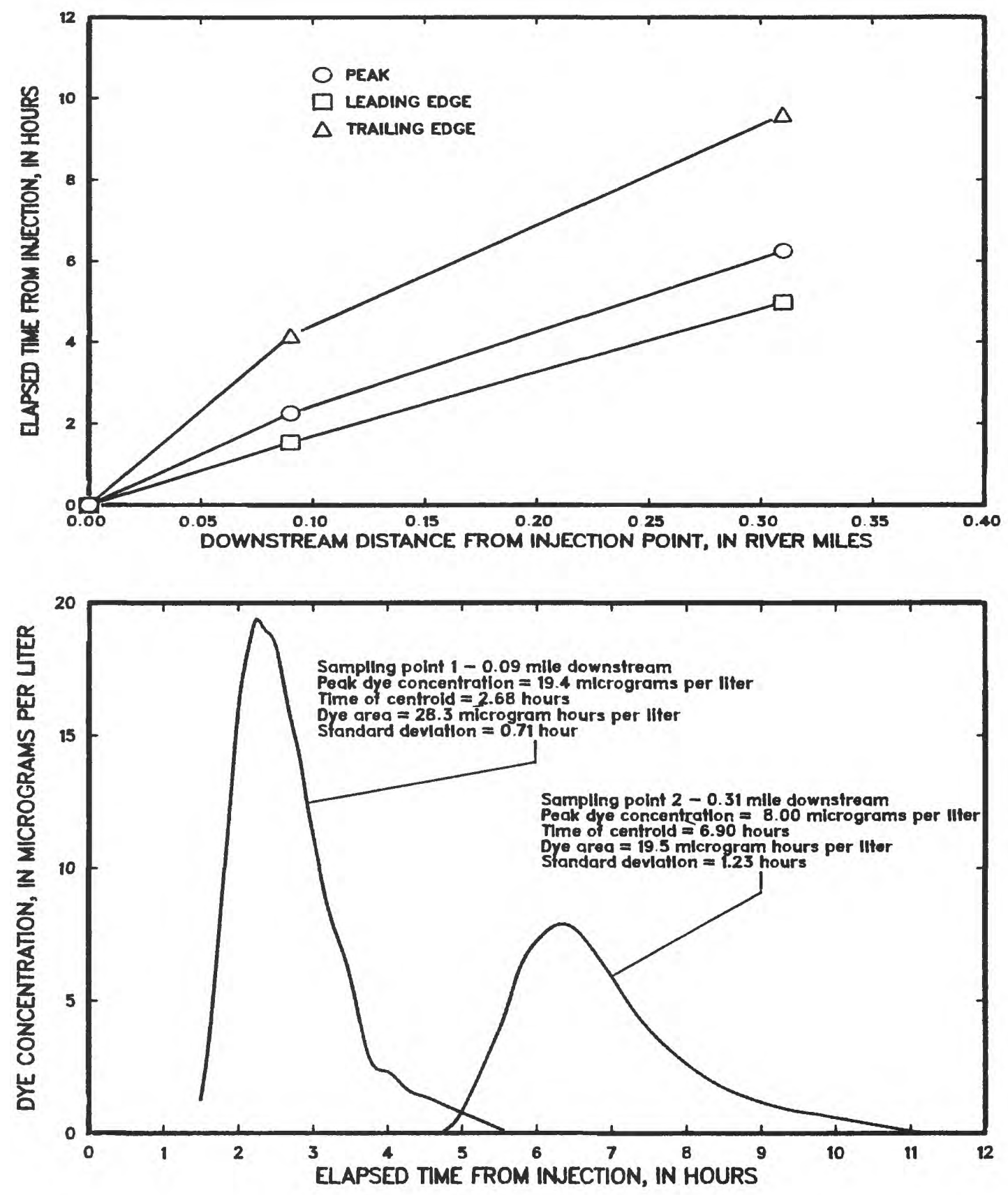

Figure 43.--Traveltime-distance and dye concentration-time curves for subreach A of Silversmith Creek at Jacksonville, August 14, 1984. 

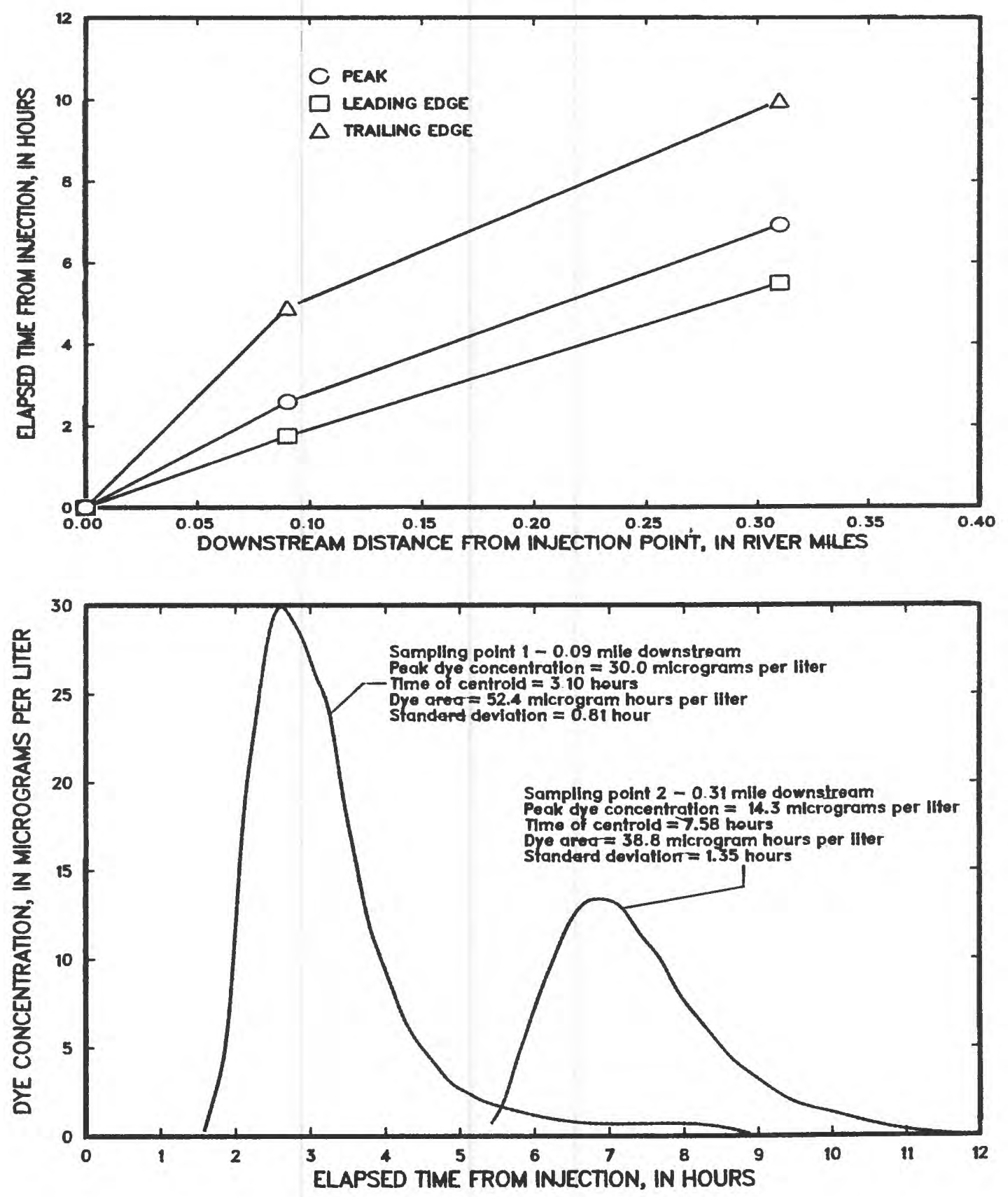

Figure 44.--Traveltime-distance and dye concentration-time curves for subreach A of Silversmith Creek at Jacksonville, May 29, 1985. 
Unnamed Tributary to Christopher Creek at Jacksonville

This unnamed tributary to Christopher Creek (fig. 45) is located east of the St. Johns River in Jacksonville. Subreach A extends 1,100 feet downstream from University Boulevard. The reach had shallow depths and little pooling. A flowing well was observed to discharge into the study reach. This subreach was studied on August 13, 1984 when the mean discharge was $0.25 \mathrm{ft}^{3} / \mathrm{s}$ and the water temperature, $28.5{ }^{\circ} \mathrm{C}$. The nearest long-term station for which low-flow frequencies were available was the Ortega River at Jacksonville. Discharge for the Ortega River at Jacksonville the day the reach was studied was $1.5 \mathrm{ft}^{3} / \mathrm{s}$. The $7 \mathrm{Q}, 10$ for the Ortega River is computed to be $0.47 \mathrm{ft}^{3} / \mathrm{s}$.

Figure 46 illustrates the times of travel of the leading edge, peak, and trailing edge of the dye cloud from the injection point to the downstream sample point and time series data for dye concentrations at the sampling points. Steady state propane concentrations at each sampling point and the reaeration coefficient for the subreach are given below.

\begin{tabular}{ccccc}
\hline Subreach & $\begin{array}{c}\text { Sampling } \\
\text { points }\end{array}$ & $\begin{array}{c}\text { Upstream } \\
\text { propane } \\
\text { concentration } \\
(\mu \mathrm{g} / \mathrm{L})\end{array}$ & $\begin{array}{c}\text { Downstream } \\
\text { propane } \\
\text { concentration } \\
(\mu \mathrm{g} / \mathrm{L})\end{array}$ & $\mathrm{K}_{\mathrm{r}}$ \\
\hline A & 1 to 2 & $1,270.0$ & 534.0 & $5.90 \pm 1.02$
\end{tabular}




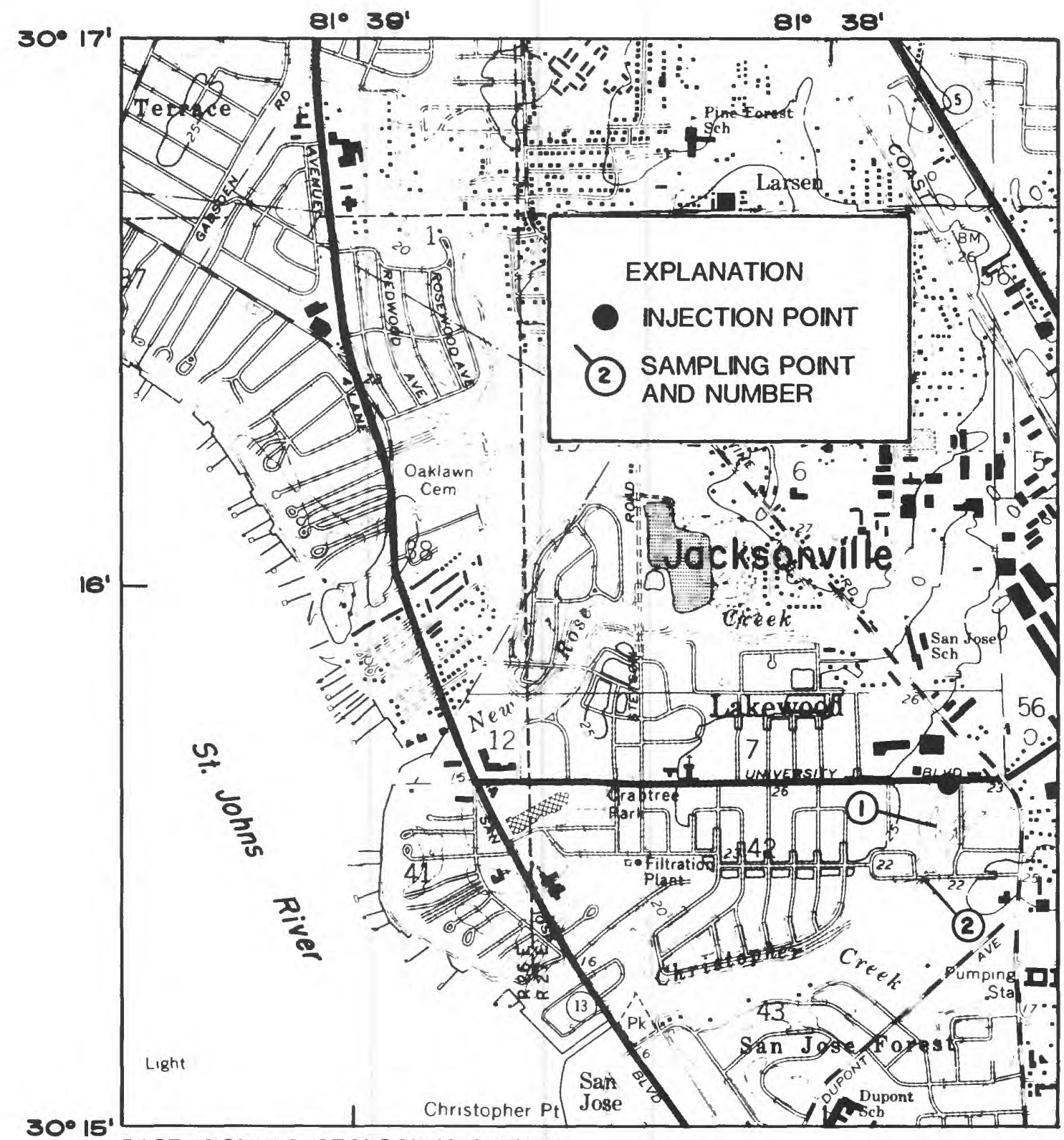

BASE FROM U.S. GEOLOGICAL SURVEY JACKSONVILLE HEIGHTS 1:24,000, 1970

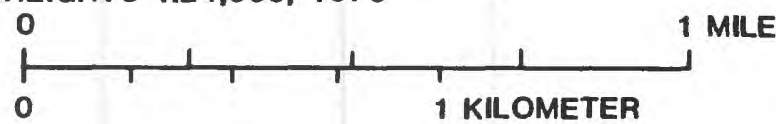

CONTOUR INTERVAL 5 FEET

NATIONAL GEODETIC VERTICAL DATUM OF 1929

\begin{tabular}{|c|c|c|c|c|c|c|c|c|}
\hline Subreach & Date & $\begin{array}{l}\text { Length } \\
\text { (feet) }\end{array}$ & $\begin{array}{l}\text { Mean } \\
\text { width } \\
\text { (feet) }\end{array}$ & $\begin{array}{l}\text { Mean cross- } \\
\text { sectional } \\
\text { area (square } \\
\text { feet) }\end{array}$ & $\begin{array}{l}\text { Mean } \\
\text { slope } \\
\text { (foot per } \\
\text { foot) }\end{array}$ & $\begin{array}{l}\text { Upstream } \\
\text { discharge } \\
\text { (cubic feet } \\
\text { per second) }\end{array}$ & $\begin{array}{l}\text { Downstream } \\
\text { discharge } \\
\text { (cubic feet } \\
\text { per second) }\end{array}$ & $\begin{array}{c}\text { Time } \\
\text { of } \\
\text { trave1 } \\
\text { (hours) }\end{array}$ \\
\hline$A-1$ to 2 & $08 / 13 / 84$ & 1,100 & 4.00 & 2.05 & 0.00369 & 0.21 & 0.29 & 2.50 \\
\hline
\end{tabular}

Figure 45.--Location of and hydraulic data for the unnamed tributary to Christopher Creek at Jacksonville. 

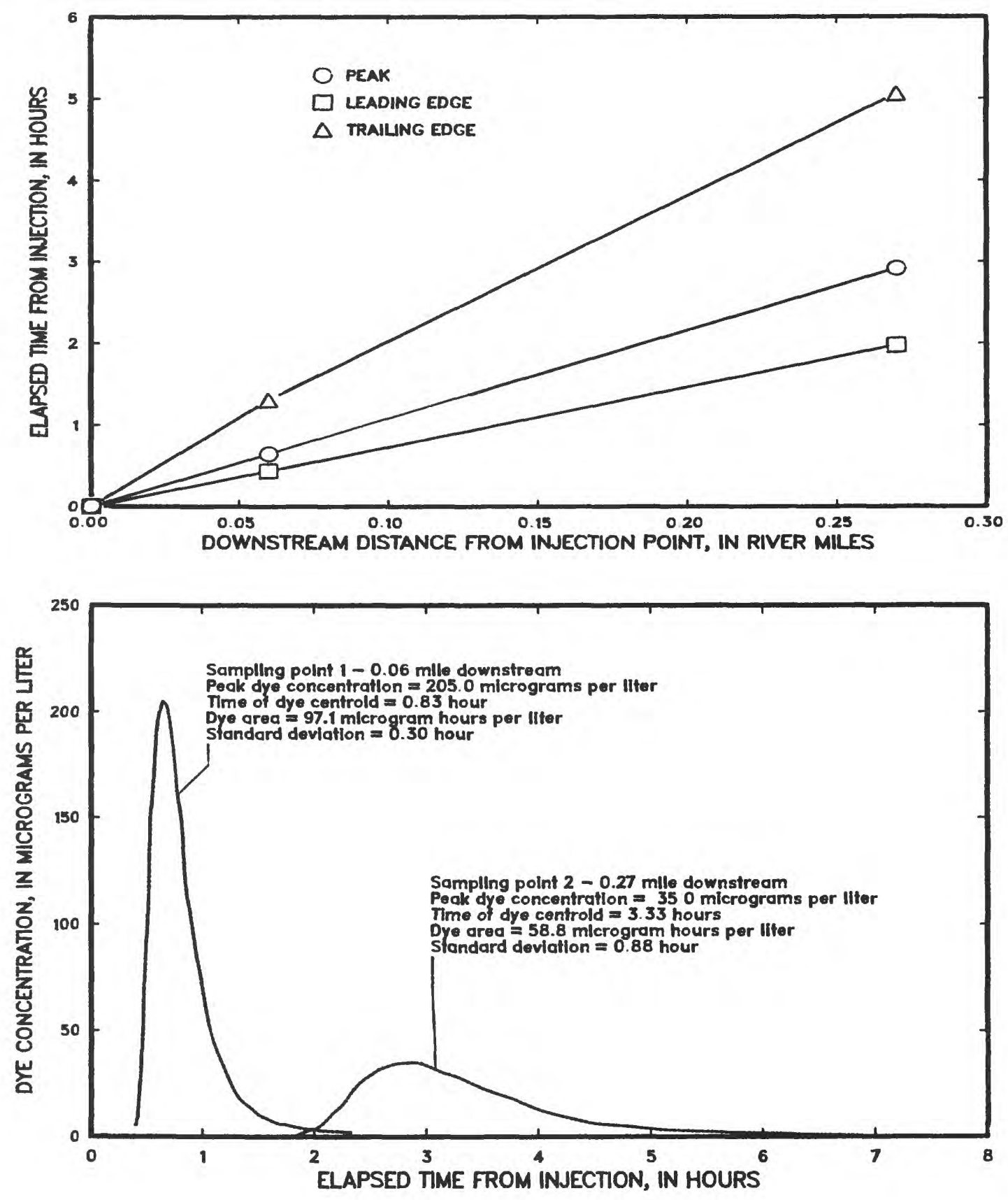

Figure 46.--Traveltime-distance and dye concentration-time curves for the unnamed tributary to Christopher Creek at Jacksonville. 


\section{Strawberry Creek at Jacksonville}

Strawberry Creek (fig. 47) is located north of the Arlington Expressway and generally parallels Mill Creek Road in Jacksonville. Subreach A which extends from Lone Star Road to Mill Creek Road was first measured on August 15, 1984. For a second study the injection point was moved approximately 500 feet upstream and sampling point 3 was added behind a private residence on Brookmont Avenue. Channel conditions were generally pool and riffle. The bottom consisted of gravel upstream and sand downstream. Bank seepage was noted in the area above Mill Creek Road. Discharge during the first study on subreach $A$ in August 1984 was $0.64 \mathrm{ft}^{3} / \mathrm{s}$ and the water temperature was $27.0^{\circ} \mathrm{C}$. During the second study in May 1985, discharge in subreach $A$ averaged $0.70 \mathrm{ft}^{3} / \mathrm{s}$ and in subreach $B$ averaged $0.78 \mathrm{ft} / \mathrm{s}$. Water temperature during the second test in May 1985 was $28.5{ }^{\circ} \mathrm{C}$ in both subreaches. The nearest long-term station for which low-flow frequencies were available was the Ortega River at Jacksonville. Discharge for the Ortega River at Jacksonville during both studies on Strawberry Creek was $1.2 \mathrm{ft} / 3$. The 7Q,10 for the Ortega River is computed to be $0.47 \mathrm{ft}^{3} / \mathrm{s}$.

Figures 48 and 49 illustrate the times of travel of the leading edge, peak, and trailing edge of the dye cloud from the injection points to the downstream sample points and time series data of dye concentrations at the sampling points. Steady state propane concentrations and computed reaeration coefficients for each of the subreaches and dates are given below.

\begin{tabular}{cccccc}
\hline Subreach & $\begin{array}{c}\text { Sampling } \\
\text { points }\end{array}$ & Date & $\begin{array}{c}\text { Upstream } \\
\text { propane } \\
\text { concentration } \\
(\mu \mathrm{g} / \mathrm{L})\end{array}$ & $\begin{array}{c}\text { Downstream } \\
\text { propane } \\
\text { concentration } \\
(\mu \mathrm{g} / \mathrm{L})\end{array}$ & $\mathrm{K}_{\mathrm{r}}$ \\
\hline & 1 to 2 & $08 / 15 / 84$ & 810.0 & 72.3 & $18.9 \pm 1.4$ \\
(days $^{-1}$ )
\end{tabular}




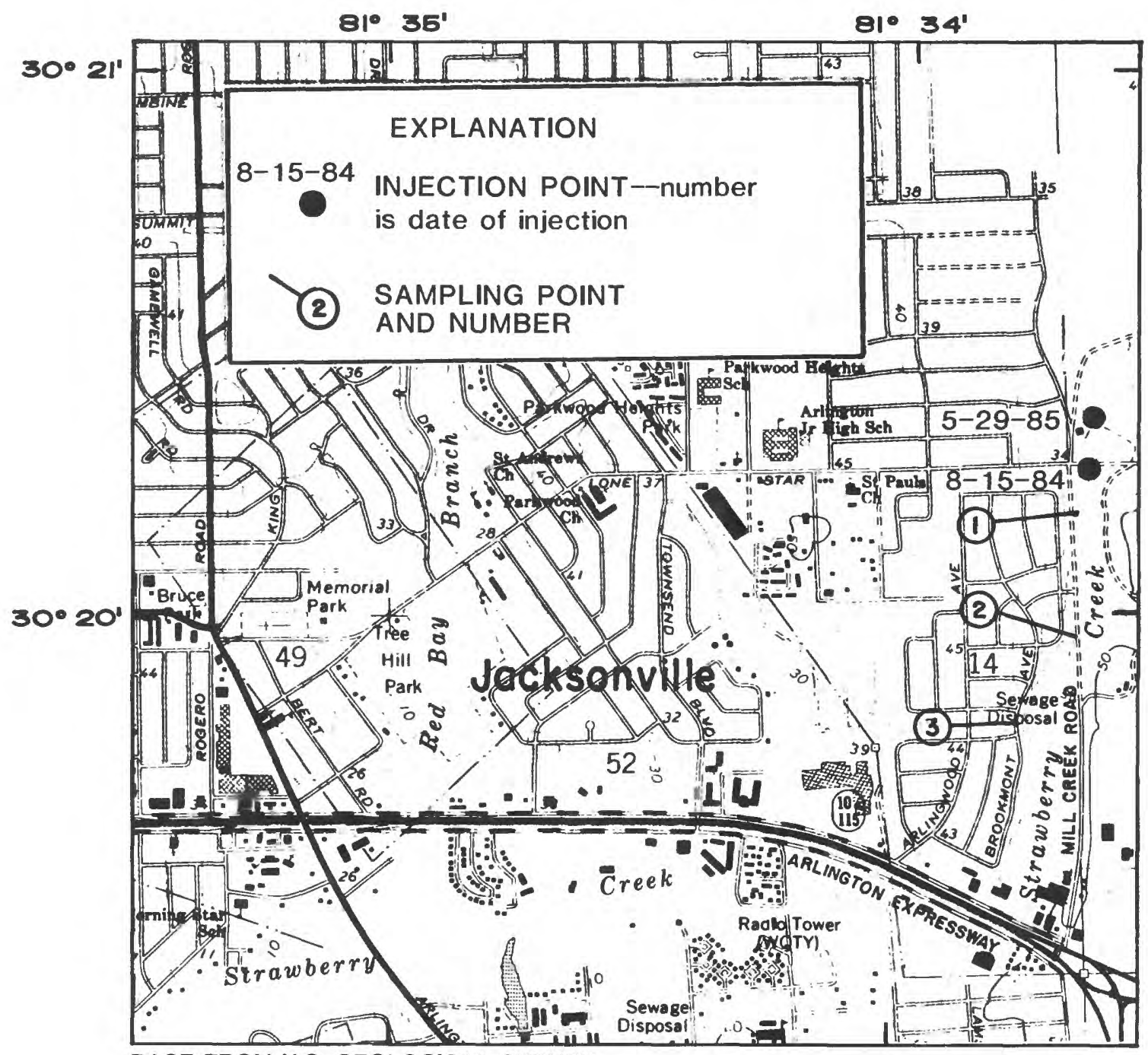

BASE FROM U.S. GEOLOGICAL SURVEY

ARLINGTON 1:24,000, 1948

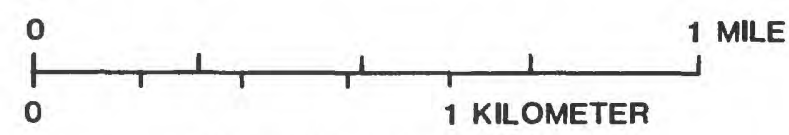

CONTOUR INTERVAL 5 FEET

NATIONAL GEODETIC VERTICAL DATUM OF 1929

\begin{tabular}{|c|c|c|c|c|c|c|c|c|}
\hline Subreach & Date & $\begin{array}{l}\text { Length } \\
\text { (feet) }\end{array}$ & $\begin{array}{l}\text { Mean } \\
\text { width } \\
\text { (feet) }\end{array}$ & $\begin{array}{l}\text { Mean cross- } \\
\text { sectional } \\
\text { area (square } \\
\text { feet) }\end{array}$ & $\begin{array}{l}\text { Mean } \\
\text { slope } \\
\text { (foot per } \\
\text { foot) }\end{array}$ & $\begin{array}{l}\text { Upstream } \\
\text { discharge } \\
\text { (cubic feet } \\
\text { per second) }\end{array}$ & $\begin{array}{l}\text { Downstream } \\
\text { discharge } \\
\text { (cubic feet } \\
\text { per second) }\end{array}$ & $\begin{array}{c}\text { Time } \\
\text { of } \\
\text { travel } \\
\text { (hours) }\end{array}$ \\
\hline $\begin{array}{l}A-1 \text { to } 2 \\
A-1 \text { to } 2 \\
B-2 \text { to } 3\end{array}$ & $\begin{array}{l}08 / 15 / 84 \\
05 / 29 / 85 \\
05 / 29 / 85\end{array}$ & $\begin{array}{l}1,800 \\
1,800 \\
1,000\end{array}$ & $\begin{array}{l}6.35 \\
7.18 \\
5.58\end{array}$ & $\begin{array}{l}3.84 \\
6.76 \\
8.19\end{array}$ & $\begin{array}{r}0.000385 \\
.000385 \\
.000340\end{array}$ & $\begin{array}{r}0.51 \\
.64 \\
.75\end{array}$ & $\begin{array}{r}0.77 \\
.75 \\
.81\end{array}$ & $\begin{array}{l}3.00 \\
4.83 \\
2.92\end{array}$ \\
\hline
\end{tabular}

Figure 47.--Location of and hydraulic data for Strawberry Creek at Jacksonville. 

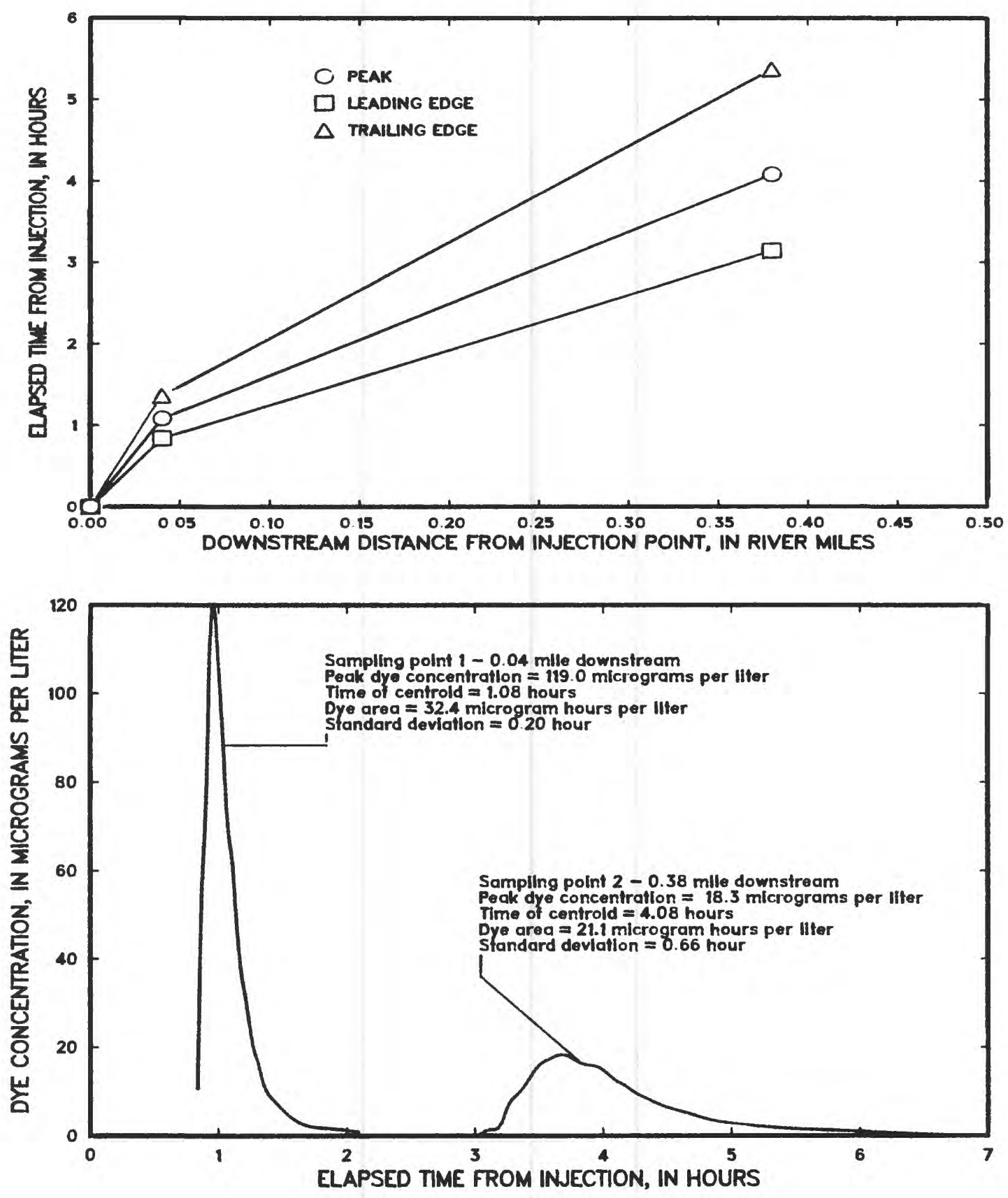

Figure 48.--Traveltime-distance and dye concentration-time curves for subreach A of Strawberry Creek at Jacksonville, August 15, 1984. 

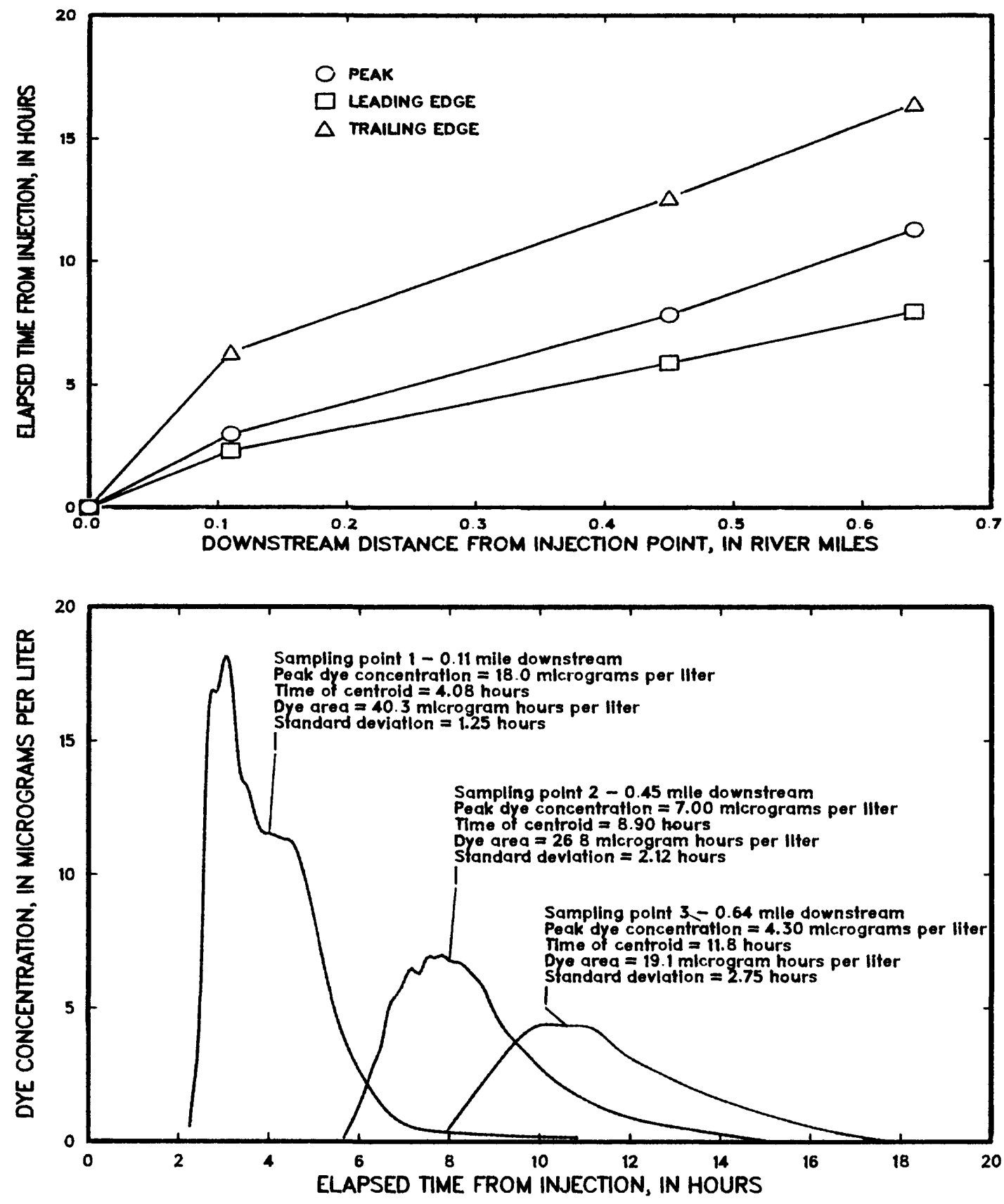

Figure 49.--Traveltime-distance and dye concentration-time curves for subreaches A and B of Strawberry Creek at Jacksonville, May 29, 1985. 
One of the purposes of the study was to evaluate the reliability of several predictive equations for the reaeration coefficient by comparison with the results of field measurements. The predictive equations attempt to relate the reaeration coefficient to hydraulic characteristics of the streams. The 10 equations chosen for evaluation were taken from Rathbun (1977), Grant and Skavronek (1981), and House and Skavronek (1981) and are given in table 1 . These equations are among the most commonly used and are generally considered the most accurate. For this evaluation, all values used for hydraulic characteristics are averages for the stream subreaches. These values have been given in the previous section, with the exception of mean hydraulic depth. For the purposes of this report, mean hydraulic depth was computed as the mean cross-sectional area divided by the mean top width. Mean top width was determined from field measurements.

Application of the 10 predictive equations using data collected during this investigation yielded a wide range of coefficient values. The standard errors of estimate for the predicted coefficients versus the measured values using the 10 equations are given in table 1 . The standard errors of estimate in percent of the mean measured reaeration coefficient ranged from 60.3 percent for the Krenke1 and orlob relation to 135.8 percent for the 0 'Connor and Dobbins relation.

With the exception of the Bennett and Rathbun equation, it was observed that all of the predictive equations markedly underestimated the measured coefficients. To determine if the predictive equation estimates could be improved by multiplication of the equation by a constant value, linear regression constrained to an origin intercept was performed on the equation predictions against the measured coefficients. In general, multiplication of the predictive equations by a constant factor (shown in table 2 as the regression coefficient) resulted in improved estimates of the measured reaeration coefficients. The best equations with respect to regression analysis were 1.13 times the Krenkel and orlob equation with a standard error of 57.4 percent, 21.48 times the $0^{\prime}$ Connor and Dobbins equation with standard error of 57.5 percent, and 3.47 times the Parkhurst and Pomeroy equation with a standard error of 61.4 percent. Even though the regression coefficients resulted in reduced standard errors of the predicted estimates, the relational aspects of these transformations with regard to specific hydraulic characteristics were not assessed. 
Table 1.--Predictive equations for reaeration coefficients and standard errors of estimate of predicted versus measured values

\begin{tabular}{|c|c|c|c|c|}
\hline $\begin{array}{l}\text { Equa- } \\
\text { tion } \\
\text { num- } \\
\text { ber }\end{array}$ & Source & Equations & $\begin{array}{l}\text { Standard } \\
\text { error of } \\
\text { estimate } \\
\left.\text { (days }{ }^{-1}\right)\end{array}$ & $\begin{array}{l}\text { Standard } \\
\text { error, } \\
\text { in } \\
\text { percent }\end{array}$ \\
\hline 1 & $\begin{array}{l}\text { Bennett and } \\
\text { Rathbun (1972) }\end{array}$ & $\mathrm{K}_{2}=20.18 \mathrm{v}^{0.607} \mathrm{H}^{-1.689}$ & 7.50 & 77.6 \\
\hline 2 & $\begin{array}{l}\text { Churchil1 and } \\
\text { others (1962) }\end{array}$ & $\mathrm{K}_{2}=11.6 \mathrm{v}^{0.969} \mathrm{H}^{-1.67}$ & 10.3 & 106.3 \\
\hline 3 & $\begin{array}{l}\text { Isaacs and } \\
\text { Gaudy (1968) }\end{array}$ & $\mathrm{K}_{2}=8.61 \mathrm{VH}^{-1.5}$ & 11.4 & 118.1 \\
\hline 4 & $\begin{array}{l}\text { Krenkel and } \\
\text { Orlob (1963) }\end{array}$ & $\mathrm{K}_{2}=234(\mathrm{VS}) \mathrm{H}^{0.408} \mathrm{H}^{-0.66}$ & 5.83 & 60.3 \\
\hline 5 & $\begin{array}{l}\text { Langbein and } \\
\text { Durum (1967 }\end{array}$ & $\mathrm{K}_{2}=7.61 \mathrm{VH}^{-1.33}$ & 11.9 & 122.6 \\
\hline 6 & $\begin{array}{l}\text { Negulescu and } \\
\text { Rojanski (1969) }\end{array}$ & $\mathrm{K}_{2}=10.91(\mathrm{~V} / \mathrm{H})^{0.85}$ & 11.3 & 116.4 \\
\hline 7 & $\begin{array}{l}\text { O'Connor and } \\
\text { Dobbins (1958) }\end{array}$ & $\mathrm{K}_{2}=12.27(\mathrm{VS}) \cdot \mathrm{H}^{-1.3}$ & 13.1 & 135.8 \\
\hline 8 & $\begin{array}{l}\text { Padden and Gloyna } \\
\text { (1971) }\end{array}$ & $\mathrm{K}_{2}=6.86 \mathrm{~V}^{0.703} \mathrm{H}^{-1.034}$ & 11.5 & 118.9 \\
\hline 9 & $\begin{array}{l}\text { Parkhurst and } \\
\text { Pomeroy (1972) }\end{array}$ & $\mathrm{K}_{2}=48.36(1+0$ & 10.6 & 109.7 \\
\hline 10 & $\begin{array}{l}\text { Tsivoglou and } \\
\text { Neal (1976) }\end{array}$ & $\begin{aligned} \mathrm{K}_{2}= & \mathrm{C}(\mathrm{dh} / \mathrm{T}) \\
\mathrm{C} & =2.64 \text { when } 1<\mathrm{Q}<10 \\
& \mathrm{C}=1.30 \text { when } 25<\mathrm{Q}<3,000\end{aligned}$ & 9.48 & 98.1 \\
\hline
\end{tabular}

The following symbols are used in the equations listed:

$\mathrm{H}=$ mean hydraulic depth, in feet;

$\mathrm{V}=$ mean velocity, in feet per second;

$S=$ slope of energy grade line, in foot per foot;

$\mathrm{dh}=$ decrease in water-surface elevation, in feet;

$T=$ travel time, in hours;

$Q=$ discharge, in cubic feet per second;

$\mathrm{F}=$ Froude number $=\mathrm{V} /(\mathrm{gH})^{1}{ }_{2}$, where $\mathrm{g}=$ acceleration due to gravity, 32.17 feet per second squared; and

$\mathrm{K}_{2}=$ predicted reaeration coefficient, in reciprocal days. 
Table 2.--Regression coefficients and standard errors of estimate for adjusted predictive equations using predicted versus measured values

\begin{tabular}{clccc}
\hline $\begin{array}{c}\text { Equation } \\
\text { number }\end{array}$ & \multicolumn{1}{c}{ Equation source } & $\begin{array}{c}\text { Regression } \\
\text { coefficient }\end{array}$ & $\begin{array}{c}\text { Standard } \\
\text { error of } \\
\text { estimate } \\
\text { days }\end{array}$ & $\begin{array}{c}\text { Standard } \\
\text { error, } \\
\text { in } \\
\text { percent }\end{array}$ \\
\hline & Bennett and Rathbun (1972) & 0.87 & 7.18 & 74.3 \\
1 & Churchill and others (1962) & 2.44 & 7.75 & 80.2 \\
2 & Isaacs and Gaudy (1968) & 3.77 & 7.91 & 81.9 \\
3 & Krenkel and Orlob (1963) & 1.13 & 5.55 & 57.4 \\
4 & Langbein and Durum (1967) & 4.58 & 8.14 & 84.2 \\
5 & Negulescu and Rojanski (1969) & 2.97 & 8.79 & 91.0 \\
6 & O'Connor and Dobbins (1958) & 21.48 & 5.56 & 57.5 \\
7 & Padden and Gloyna (1971) & 4.15 & 7.53 & 77.9 \\
8 & Parkhurst and Pomeroy (1972) & 3.47 & 5.93 & 61.4 \\
9 & Tsivoglou and Neal (1976) & 2.46 & 6.01 & 62.2 \\
\hline 0 & & & &
\end{tabular}

Examination of the equations presented in table 1 suggests that, in general, four types of functional relations are utilized. For the purposes of this report, these will be referred to as (1) the Bennett type--a power of velocity divided by a power of depth; (2) the Krenkel type--a power of velocity times slope divided by a power of depth; (3) the Parkhurst type--similar to Krenkel but with a term employing the Froude number; and (4) the Tsivoglou type--a function of the decrease in water elevation divided by the travel time. Seven equations utilizing these functional relationships were developed by nonlinear regression with the measured reaeration coefficients. Nonlinear regressions were performed using the modified Gauss-Newton method with the NLIN procedure developed by the SAS Institute, Inc. ${ }^{1}$ (1982). The results are given in table 3 . These equations represent the best least-square estimates of the four functional relations given above. As shown in table 3, the nonlinear regression equations do not show much improvement over the linear regression estimates given earlier. The standard errors of estimate ranged from 54.9 percent for the equation 4 in table 3 to 65.4 percent for equation 1 .

${ }^{1}$ Use of brand, trade, or firm names in this report is for identification purposes only and does not constitute endorsement by the U.S. Geological Survey. 
Table 3.-- Seven modified predictive equations developed by nonlinear regression for reaeration coefficients using measured data and standard errors of estimate of predicted versus measured values

\begin{tabular}{|c|c|c|c|c|}
\hline $\begin{array}{l}\text { Equation } \\
\text { No. }\end{array}$ & $\begin{array}{l}\text { Equation } \\
\text { type }\end{array}$ & Regression equation for $K$ & $\begin{array}{l}\text { Standard } \\
\text { error of } \\
\text { estimate } \\
\text { (days }^{-1} \text { ) }\end{array}$ & $\begin{array}{l}\text { Standard } \\
\text { error, } \\
\text { in } \\
\text { percent }\end{array}$ \\
\hline 1 & Bennett & $13.32 \mathrm{v}^{0.138} \mathrm{H}^{-1.093}$ & 6.32 & 65.4 \\
\hline 2 & Krenkel & $1,099.83(\mathrm{VS})^{0.596} \mathrm{H}^{-0.477}$ & 5.54 & 57.3 \\
\hline 3 & Parkhurst & $\left.268.42\left(1.0-27.15 \mathrm{~F}^{2}\right)(\mathrm{VS})\right)^{0.425 \mathrm{H}^{-1}}$ & 5.83 & 60.3 \\
\hline 4 & Parkhurst & $4,042.77\left(1.0-35.87 \mathrm{~F}^{2}\right)(\mathrm{VS}){ }^{0.750} \mathrm{H}^{-0.373}$ & 5.30 & 54.9 \\
\hline 5 & Tsivoglou & $7.06(\mathrm{dh} / \mathrm{T})^{0.930}$ & 5.95 & 61.6 \\
\hline 6 & Tsivoglou & $5.22(\mathrm{dh})^{1.075}(\mathrm{~T})^{-0.920}$ & 5.95 & 61.6 \\
\hline 7 & Tsivoglou & $6.48(\mathrm{dh} / \mathrm{T})$ & 5.99 & 62.0 \\
\hline
\end{tabular}

The following symbols are used in the equations 1isted:

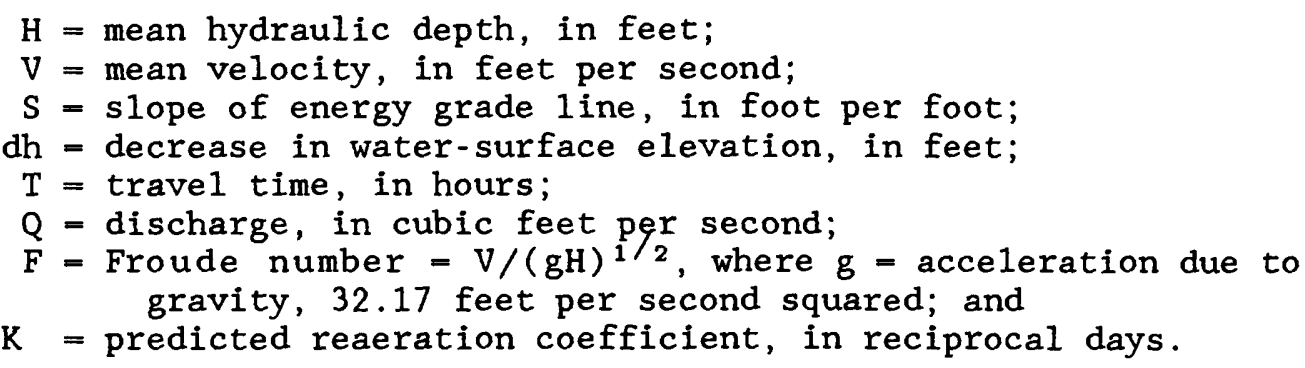

Analysis of variance procedures were used with al1 of the above predictive equations to determine if the accuracies of prediction were significantly related to stream size. The differences between predicted and measured values for each equation were analyzed with respect to measures of stream size such as discharge, width, and cross-sectional area. None of the measures were found to be significantly related to the errors at probabilities greater than an 80 percent significance level, indicating that the present data cannot support use of any particular equation. 


\section{SUMMARY AND CONCLUSIONS}

Reaeration coefficient determinations were performed on 27 subreaches of 12 selected Florida streams. The measurements were performed during periods of relatively low flows occurring between October 1981 and May 1985. Measurements performed prior to June 1984 were made by the peak and area methods with propane and ethylene as the tracer gases. Later measurements were made by the steady-state method with propane as the tracer gas.

The reaeration coefficient values ranged from 1.07 to 45.9 days $^{-1}$ with an estimated mean probable error of \pm 16.7 percent. Estimated probable errors were calculated for each determination on the bas is of standard relative errors of \pm 2 percent for hydrocarbon gas analyses and Rhodamine-WT dye determinations and \pm 5 to 8 percent for discharge measurements. For the steady-state determinations, standard relative errors of the hydrocarbon gas concentration data were calculated from a minimum of five sample analysis results. Estimated probable errors for the determinations ranged from 2.7 percent to 82 percent, depending on streamflow and other conditions at the time of measurement. For the peak and area determinations, the final reaeration coefficient values were calculated by weighting the propane and ethylene results relative to the estimated error of determination.

For 5 of the 13 subreaches in which both propane and ethylene gases were used, the ethylene data resulted in substantially larger reaeration coefficient values, which were rejected. Ethylene coefficients were rejected if Student's $t$ statistic calculated using the estimated standard deviations of propane and ethylene values indicated a 95 percent or greater probability of significant difference. Probabilities for the values actually rejected al1 exceeded 97 percent. In these cases, only the lower and more conservative propane results were used for a final reaeration coefficient value.

The significantly greater reaeration coefficients yielded by the ethylene data for these subreaches probably result from the greater reactivity of the ethylene molecule. In aqueous media, the most probable reactions are, in order of thermodynamic favorability; halogen addition, halohydrin formation, water addition, and hydrogen halide addition. In general, ethylene can be expected to be significantly reactive in the presence of halogens such as chlorine or substantial sources of acidity.

Using the measured reaeration coefficient values, 10 commonly used predictive equations were evaluated. These equations attempt to determine reaeration coefficients from the hydraulic characteristics of the stream of interest. The most accurate equation evaluated during this study was that proposed by Krenkel and Orlob which resulted in a standard error of estimate of 5.83 days $^{-}$or 60.3 percent. The accuracy of many of these equations was enhanced by multiplication by a constant. The constants were determined by linear regression of predicted and measured values constrained to an origin intercept. The most accurate equation developed by this means multiplied the Krenkel and Orlob $_{1}$ result by 1.13 and reduced the standard error of estimate to 5.55 days $^{-1}$ or 57.4 percent. 
Seven additional predictive equations were developed from the measured reaeration coefficients by nonlinear regression. These equations took the four different functional forms exhibited by the 10 original equations. The most accurate of these equations had the functional form of the Parkhurst and Pomeroy equation and a standard error of estimate of 5.30 days or 54.9 percent. This equation represents the best possible least-squares fit of the measured data using the functional relations developed by previous investigators and indicates that estimates of reaeration coefficients based upon functions developed in the past may be subject to considerable error for Florida streams. 


\section{SELECTED REFERENCES}

Bennett, J.P., and Rathbun, R.E., 1972, Reaeration in open-channel flow: U.S. Geological Survey Professional Paper 737, 75 p.

Buchanan, T.J., and Somers, W.P., 1969, Discharge measurements at gaging stations: U.S. Geological Survey Techniques of Water-Resources Investigations, Book 3, Chapter A-8, 65 p.

Churchill, M.A., Elmore, H.L., and Buckingham, R.A., 1962, The prediction of stream reaeration rates: American Society of Civil Engineers, v. 88, no. SA4, p. 1-46.

Daniels, Farrington, Alberty, R.A., Williams, J.W., Cornwell, C.D., Bender, Paul, and Harriman, J.E., 1970, Experimental physical chemistry: New York, McGraw-Hill, 669 p..

Elmore, H.L., and West, W.F., 1961, Effect of water temperature on stream reaeration: Journal of the Sanitary Engineering Division, Proceedings of the American Society of Civil Engineers, v. 87, no. SA6, p. 59-71.

Feltz, H.R., and Anthony, E.R., eds., 1984, 1985 Water quality laboratory services catalog: U.S. Geological Survey Open-File Report 84-171, $69 \mathrm{p}$.

Grant, R.S., 1976 (1977), Reaeration-coefficient measurements of 10 small streams in Wisconsin using radioactive tracers, with a section on the energy dissipation model: U.S. Geological Survey Water-Resources Investigations $76-96,56 \mathrm{p}$.

-..-1978, Reaeration capacity of the Rock River between Lake Koshkonong, Wisconsin, and Rockton, Illinois: U.S. Geological Survey WaterResources Investigations 77-128, $38 \mathrm{p}$.

Grant, R.S., and Skavronek, Steven, 1981, Comparison of tracer methods and predictive equations for determination of stream reaeration on three small streams in Wisconsin: U.S. Geological Survey Water-Resources Investigations $80-19,36 \mathrm{p}$.

Hayes, E.C., 1978, 7-day low flows and flow duration of Alabama streams through 1973: Geological Survey of Alabama Bulletin 113, $163 \mathrm{p}$.

House, L.B., and Skavronek, Steven, 1981, Comparison of the propane-area tracer method and predictive equations for determination of stream reaeration on two small streams in Wisconsin: U.S. Geological Survey Water-Resources Investigations 80-105, $23 \mathrm{p}$.

Hughes, G.H., 1981, Low-flow frequency data for selected stream-gaging stations in Florida: U.S. Geological Survey Water-Resources Investigations 81-69, 110 p.

Isaacs, W.P., and Gaudy, A.F., 1968, Atmospheric oxygenation in a simulated stream: Journal of the Sanitary Engineering Division, Proceedings of the American Society of Civil Engineers, v. 94, no. SA2, Proceedings Paper 5905, p. 319-344.

Kilpatrick, F.A., and Cobb, E.R., 1984, Measurement of discharge using tracers: U.S. Geological Survey Open-File Report 84-136, 73 p.

Krenkel, P.A., and Orlob, G.T., 1963, Turbulent diffusion and the reaeration coefficient: Transactions of the American Society of Civil Engineers, v. 128, Part III, Paper no. 3491, p. 293-334.

Langbein, W.B., and Durum, W.H., 1967, The aeration capacity of streams: U.S. Geological Survey Circular 542, 6 p.

Morrison, R.T., and Boyd, R.N., 1973, Organic chemistry: Boston, Allyn and Bacon, Inc., $1258 \mathrm{p}$.

Negulescu, M., and Rojanski, V., 1969, Recent research to determine reaeration coefficients: Water Research, v. 3, no. 3, p. 189-202.

O'Connor, D.J., and Dobbins, W.E., 1958, Mechanism of reaeration in natural streams: Transactions of the American Society of Civil Engineers, $v$. 123, p. 641-684. 
Padden, T.J., and Gloyna, E.G., 1971, Simulation of stream processes in a model river: Austin, University of Texas, Report no. EHE-70-23, CRWR-72, $130 \mathrm{p}$.

Parkhurst, J.D., and Pomeroy, R.D., 1972, Oxygen absorption in streams: Journal of the Sanitary Engineering Division, Proceedings of the American Society of Civil Engineers, v. 98, no. SAl, Proceedings Paper 8701 , p. 101-124.

P-STAT, Inc., 1983, P-STAT User's Manual: Princeton, N.J., 719 p.

Rainwater, K.A., and Holley, E.R., 1984, Laboratory studies on hydrocarbon tracer gases: American Society of Civil Engineers Journal, v. 110, no. 1, Feb., p. 27-41.

Rathbun, R.E., 1977, Reaeration coefficients of streams--state-of-the-art: Journal of the Hydraulics Division, Proceedings of the American Society of Civil Engineers, v. 103, no. H-Y4, p. 409-424.

-...1979, Estimating the gas and dye quantities for modified tracer technique measurements of stream reaeration coefficients: U.S. Geological Survey Water-Resources Investigations 79-27, $42 \mathrm{p}$.

Rathbun, R.E., and Grant, R.S., 1978, Comparison of the radioactive and modified techniques for measurement of stream reaeration coefficients: U.S. Geological Survey Water-Resources Investigations 78-68, $57 \mathrm{p}$.

Rathbun, R.E., Shultz, D.J., and Stephens, D.W., 1975, Preliminary experiments with a modified tracer technique for measuring stream reaeration coefficients: U.S. Geological Survey Open-File Report $75-256,36 \mathrm{p}$.

Rathbun, R.E., Stephens, D.W., Shultz, D.J., and Tai, D.Y., 1978, Laboratory studies of gas tracers for reaeration: Journal of the Environmental Engineering Division, Proceedings of the American Society of Civil Engineers, v. 104, no. EE2 p. 215-229.

SAS Institute, Inc., 1982, SAS User's Guide: Gary, N.C., Statistics, SAS Institute, $584 \mathrm{p}$.

Shultz, D.J., Pankow, J.F., Tai, D.Y., Stephens, D.W., and Rathbun, R.E., 1976, Determination, storage, and preservation of low molecular weight hydrocarbon gases in aqueous solution: U.S. Geological Journal of Research, v. 4, no. 2, p. 247-251.

Streeter, H.W., and Phelps, E.B., 1925, A study of the pollution and natural purification of the Ohio River. III. Factors concerned in the phenomena of oxidation and reaeration: U.S. Public Health Service, Public Health Bulletin no. 146, Washington, D.C.

Tsivoglou, E.C., 1967, Tracer measurement of stream reaeration: Federal Water Pollution Control Administrative Report, $86 \mathrm{p}$.

Tsivoglou, E.C., Cohen, J.B., Shearer, S.D., and Godsil, P.J., 1968, Field studies, Part II of Tracer measurement of stream reaeration: Journal Water Pollution Control Federation, v. 40, no. 2, p. 285-305.

Tsivoglou, E.C., and Neal, L.A., 1976, Predicting the reaeration capacity of inland streams, in Tracer measurement of reaeration, Part III: Journal Water Pollution Control Federation, v. 48, no. 12, p. 2669-2688.

Tsivoglou, E.C., O'Conne11, R.L., Walter, C.M., Godsil, P.J., and Logsdon, G.S., 1965, Tracer measurements of atmospheric reaeration, I. Laboratory studies: Journal Water Pollution Control Federation, v. 37, no. 10, p. 1343-1362.

Wilson, J.F., Jr., Cobb, E.D., and Kilpatrick, F.A., 1984, Fluorometric procedures for dye tracing: U.S. Geological Survey Open-File Report 84-234, $53 \mathrm{p}$.

Yotsukura, N., Stedfast, D.A., Draper, R.E., and Brutsaert, W.H., 1983, An assessment of steady-state propane-gas tracer method for reaeration coefficients--Cowaselon Creek, New York: U.S. Geological Survey WaterResources Investigations 83-4183, 88 p. 


\section{APPENDIX I.--ESTIMATION AND PROPAGATION OF EXPERIMENTAL ERRORS}

Final physical-chemical results are usually obtained by combining the results of different kinds of measurements. The accuracy of a final result is influenced by the accuracy of the measurements of the different quantities involved. A result, $\mu$, calculated from a set of experimentally derived quantities $\mathrm{x}, \mathrm{y}, \mathrm{z}, \ldots$, constitutes a function dependent on the values assumed for these quantities as independent variables. Differential changes in the final results corresponding to differential changes in the independent variables can be given by the expression for the exact differential of a function of several independent variables. In the case of three independent variables, the expression would be;

$$
\mathrm{d} \mu=\left(\frac{\partial \mu}{\partial \mathrm{x}}\right)_{\mathrm{y}, \mathrm{z}} \mathrm{dx}+\left(\frac{\partial \mu}{\partial \mathrm{y}}\right)_{\mathrm{x}, \mathrm{z}} \mathrm{dy}+\left(\frac{\partial \mu}{\partial z}\right)_{\mathrm{x}, \mathrm{y}} \mathrm{dz}
$$

The expression can obviously be extended to a larger or smaller number of variables. The partial derivatives are derived from the relation for calculating the final result. The variations $\mathrm{dx}$, dy, and $\mathrm{dz}$ correspond to the uncertainties in the experimental data.

The standard deviation of the final result can be expressed using the standard formula;

$$
\sigma_{\mu}=\left[\frac{1}{\mathrm{n}-1}\left(\sum_{i=1}^{\mathrm{n}}\left(\mathrm{d} \mu_{i}\right)^{2}\right)\right]^{1 / 2}
$$

or,

$$
\sigma_{\mu}^{2}=\frac{1}{\mathrm{n}-1} \sum_{i=1}^{\mathrm{n}}\left(\mathrm{d} \mu_{i}\right)^{2}
$$

Using two variables, $x$ and $y$, for simplicity; the following expression results;

$$
\begin{aligned}
\left(\mathrm{d} \mu_{i}\right)^{2} & =\left[\left(\frac{\partial \mu}{\partial x}\right)_{y} d x_{i}+\left(\frac{\partial \mu}{\partial y}\right)_{x} d y_{i}\right]^{2} \\
& =\left(\frac{\partial \mu}{\partial x}\right)_{y}^{2}\left(d x_{i}\right)^{2}+2\left(\frac{\partial \mu}{\partial x}\right)_{y}\left(\frac{\partial \mu}{\partial y}\right)_{x} d x_{i} d y_{i}+\left(\frac{\partial \mu}{\partial y}\right)_{x}^{2}\left(d_{i}\right)^{2} .
\end{aligned}
$$

If the errors are random and therefore governed by a gaussian distribution, positive and negative deviations will be equally probable. The crossproduct terms will therefore tend to cancel and may be dropped if the errors in $x$ and $y$ are uncorrelated. Substitution of this result into the expression for the standard deviation gives;

$$
\sigma_{\mu}^{2}=\frac{1}{n-1} \sum_{i=1}^{n}\left[\left(\frac{\partial \mu}{\partial x}\right)_{y}^{2}\left(d x_{i}\right)^{2}+\left(\frac{\partial \mu}{\partial y}\right)_{x}^{2}\left(d y_{i}\right)^{2}\right]
$$


or;

$$
\sigma_{\mu}^{2}=\left(\frac{\partial \mu}{\partial x}\right)_{y}^{2} \sigma_{x}^{2}+\left(\frac{\partial \mu}{\partial y}\right)_{x}^{2} \sigma_{y}^{2} .
$$

If the error distribution is random, 68.3 percent of all results are predicted to be within one standard deviation of the mean. The probable error is defined as;

$$
\mathrm{P}_{\mu}=0.6745 \sigma_{\mu} \text {, a linear function of the }
$$

standard deviation, therefore, the expression;

$$
\mathrm{P}_{\mu}^{2}=\left(\frac{\partial \mu}{\partial \mathrm{x}}\right)_{\mathrm{y}}^{2} \mathrm{P}_{\mathrm{x}}^{2}+\left(\frac{\partial \mu}{\partial \mathrm{y}}\right)_{\mathrm{x}}^{2} \mathrm{P}_{\mathrm{y}}^{2} \text { is also valid. }
$$

With a random error distribution, 50 percent of all results are predicted to be within one probable error of the mean.

With suitable changes in variables, the above expressions can be applied to the formulae for calculation of reaeration coefficients using estimated errors for the experimentally derived quantities. This application, however, results in rather cumbersome algebraic expressions which will not be given here. Further derivation, if desired, is left to the reader. 